\title{
Chronic Kidney Disease-Associated Itch (CKD-aI) in Children-A Narrative Review
}

\author{
Radomir Reszke ${ }^{1}$, Katarzyna Kiliś-Pstrusińska ${ }^{2, *(D)}$ and Jacek C. Szepietowski ${ }^{1, *(D)}$ \\ 1 Department of Dermatology, Venereology and Allergology, Wrocław Medical University, \\ 1 Chałubińskiego Street, 50-368 Wrocław, Poland; radomir.reszke@umed.wroc.pl \\ 2 Department of Paediatric Nephrology, Wrocław Medical University, 213 Borowska Street, \\ 50-556 Wrocław, Poland \\ * Correspondence: katarzyna.kilis-pstrusinska@umed.wroc.pl (K.K.-P.); \\ jacek.szepietowski@umed.wroc.pl (J.C.S.); Tel.: +48-71-736-44-00 (K.K.-P.); +48-71-784-22-96 (J.C.S.)
}

check for

updates

Citation: Reszke, R.;

Kiliś-Pstrusińska, K.; Szepietowski,

J.C. Chronic Kidney

Disease-Associated Itch (CKD-aI) in

Children-A Narrative Review.

Toxins 2021, 13, 450. https://doi.org/ $10.3390 /$ toxins 13070450

Received: 6 June 2021

Accepted: 28 June 2021

Published: 29 June 2021

Publisher's Note: MDPI stays neutral with regard to jurisdictional claims in published maps and institutional affiliations.

Copyright: (C) 2021 by the authors. Licensee MDPI, Basel, Switzerland. This article is an open access article distributed under the terms and conditions of the Creative Commons Attribution (CC BY) license (https:/ / creativecommons.org/licenses/by/ $4.0 /)$.

\begin{abstract}
Chronic kidney disease (CKD) is a condition of widespread epidemiology and serious consequences affecting all organs of the organism and associated with significant mortality. The knowledge on CKD is rapidly evolving, especially concerning adults. Recently, more data is also appearing regarding CKD in children. Chronic itch (CI) is a common symptom appearing due to various underlying dermatological and systemic conditions. CI may also appear in association with CKD and is termed chronic kidney disease-associated itch (CKD-aI). CKD-aI is relatively welldescribed in the literature concerning adults, yet it also affects children. Unfortunately, the data on paediatric CKD-aI is particularly scarce. This narrative review aims to describe various aspects of CKD-aI with an emphasis on children, based on the available data in this population and the data extrapolated from adults. Its pathogenesis is described in details, focusing on the growing role of uraemic toxins (UTs), as well as immune dysfunction, altered opioid transmission, infectious agents, xerosis, neuropathy and dialysis-associated aspects. Moreover, epidemiological and clinical aspects are reviewed based on the few data on CKD-aI in children, whereas treatment recommendations are proposed as well, based on the literature on CKD-aI in adults and own experience in managing CI in children.
\end{abstract}

Keywords: chronic kidney disease; uraemic toxins; children; itch

Key Contribution: This narrative review comprehensively covers pathogenesis, epidemiology, clinical picture and therapeutic approach of chronic kidney disease-associated itch (CKD-aI) in children.

\section{Introduction}

Itch (also referred to as pruritus) is defined as an unpleasant sensation leading to a desire to scratch. Based on its duration itch is classified as acute or chronic (CI), with the latter being present for more than 6 weeks in an affected individual [1]. CI may manifest in a continuous or intermittent manner, yet its long duration clearly implies an underlying disease-related context. Unsurprisingly, various conditions managed by different medical specialists are prone to be associated with CI. According to the classification proposed by the International Forum for the Study of Itch (IFSI), the aetiological causes of CI may be divided into cutaneous (I), systemic (II), neurologic (III), psychogenic (IV), mixed (V) and other (VI) [2]. Regardless of the common cutaneous diseases mostly managed by dermatologists which frequently present with CI (e.g., atopic dermatitis [AD], urticaria, psoriasis), there is a plethora of other associated chronic conditions of systemic nature, including hepatic, haematologic, oncologic, rheumatologic or renal. Regarding the latter group, a particular emphasis should be given to the spectrum of chronic kidney disease (CKD) which is defined as kidney damage or glomerular filtration rate (GFR) lower than $60 \mathrm{~mL} / \mathrm{min} / 1.73 \mathrm{~m}^{2}$ for a period of at least 3 months [3]. According to the GFR, five 
stages of CKD are mentioned, with the fifth stage (GFR $<15 \mathrm{~mL} / \mathrm{min} / 1.73 \mathrm{~m}^{2}$ ) also termed uraemia or end-stage renal disease (ESRD). The impact of CKD is vast in all regions of the world. According to Hill et al. [4], the global prevalence of CKD (all stages) was estimated as $13.4 \%$, stages $3-5$ affected $10.6 \%$ of population, whereas stage $5-0.1 \%$. In 2017 there were 697.5 million new cases of CKD recorded, with 1.2 million of deaths associated with CKD [5]. It is obvious that with such overwhelming epidemiological figures, the everyday clinical practice shall reveal marked heterogeneity in patients' characteristics, possibly with varying causes of the disease, clinical course, expected consequences and preferable clinical management. This remains valid especially in the context of age groups. Population aging and common crucial risk factors for CKD development, such presence of diabetes and hypertension, have all contributed to the growing magnitude of CKD over the last decades, especially in the elderly [5]. Unfortunately, the global CKD burden also stems from its presence in paediatric population. The prevalence of CKD varies between 15-74.7 per million children in different geographic regions [6]. In 2008, the median reported incidence of renal replacement therapy reached 9 per million children worldwide, with values ranging between 4 to 18 per million in different countries [7]. The aforementioned heterogeneity between different age groups is also expressed via the aetiological factors contributing to the development of CKD. While adults mostly develop CKD due to diabetic nephropathy, hypertension and autosomal dominant polycystic kidney disease (ADPKD), the leading causes in children encompass congenital anomalies of the kidney and urinary tract (CAKUT), hereditary nephropathies and glomerulonephritis [8]. The major CKD complications in children are cardiovascular disease (CVD) presenting with hypertension and/or dyslipidaemia, impaired cognitive development, anaemia, poor or slowed growth, decreased appetite or even death [9]. ESRD is associated with 30 times higher likelihood of mortality than in healthy children [10]. Moreover, young patients with CKD have significantly reduced health-related quality of life (HRQoL) in its various domains [11-13]; this also concerns their caregivers [13].

$\mathrm{CI}$ is also a frequent problem in the general population. According to Ständer et al. [14], the point-prevalence of $\mathrm{CI}$ in adults was $16.8 \%$, whereas Matterne et al. [15] assessed its lifetime prevalence as $25.5 \%$. The burden of CI may manifest with detrimental effect on an individual through decreased mood, reduced concentration, worse sleep quality, suicidal thoughts, difficult socioeconomic situation, feelings of stigmatization or impaired sexual life, to mention just a few [16-21]. CKD-associated itch (CKD-aI) is a well-described entity in adults with CKD. Based on recent data, it affects $42-44 \%$ of adults undergoing haemodialysis (HD) $[22,23]$, while in patients undergoing peritoneal dialysis (PD) the percentages exceed $60 \%[24,25]$. Patients who underwent successful renal transplantation (RTx) still complain of $\mathrm{CI}$ in up to $32 \%$ cases, albeit the percentages are lower than during their previous HD sessions [26-28]. However, CKD-aI may also bother CKD patients not yet on dialysis, including those with earlier stages of the disease $[23,29,30]$.

Analogously to the CKD population, studies focusing on $\mathrm{CI}$ in children are published in the literature less frequently than those referring to the adult population. Notably, $\mathrm{CI}$ in paediatric population occurring due to systemic causes has been relatively rarely investigated in the literature [31-38], while publications specifically mentioning CKD-aI appear even more exceptionally [39-44]. In this narrative review we attempted to gather the data on CKD-aI in the context of paediatric population and demonstrate the areas which require further evaluation in the future. Due to the scarcity of available papers referring to paediatric population suffering from CKD-aI, a significant proportion of considerations refers to adult CKD-aI and/or paediatric CKD patients, as reported in the literature.

We performed an extensive search of the English literature in PubMed@ and Scopus@ databases using terms "itch", "pruritus", "uraemic", "kidney", "renal", "dialysis", "children", and "paediatric", in different combinations. We also included the data from other relevant online sources on CKD $[9,45]$ which we were aware of. The search was executed on 30 April 2021. 


\section{Pathogenesis of CKD-aI}

CKD-aI is a classic example of multifactorial pathogenesis of CI. Table 1/Figure 1 lists the most important factors/groups of factors relevant in CKD-aI pathogenesis. It is important to note that the complicated network of reciprocal associations results in certain overlapping of the pathogenetic mechanisms. Therefore, the separate considerations on subsequent factors are provided in this manner for educational purposes.

Table 1. Major groups of pathogenetic factors contributing to the development of CKD-aI.

\begin{tabular}{c}
\hline Uraemic toxins (UTs) \\
Immune dysfunction \\
Altered opioid transmission \\
Infectious agents \\
Skin dryness (xerosis) \\
Neuropathy \\
Dialysis modality and its parameters \\
Others \\
\hline
\end{tabular}

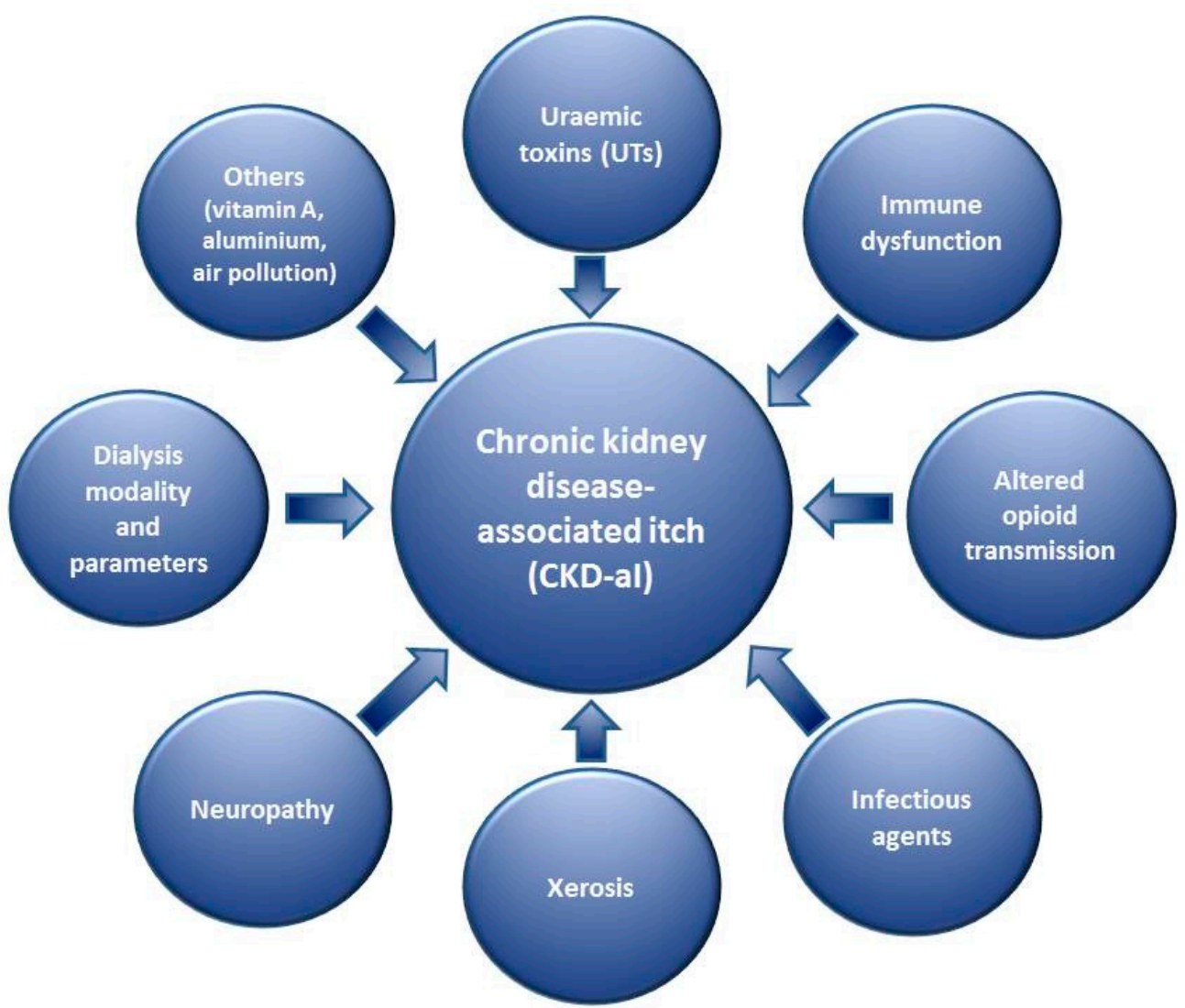

Figure 1. Major groups of pathogenetic factors contributing to the development of CKD-aI.

\subsection{Uraemic Toxins (UTs)}

Although the term "uraemia" used to be synonymous with all the signs and symptoms of advanced kidney failure, more currently it can be described as an illness accompanying kidney failure that cannot be explained by derangements in extracellular volume, inorganic ion concentrations, or the lack of known renal synthetic products (as reviewed by Meyer and Hostetter) [46]. Uraemic toxins (UTs) constitute a heterogenous group of substances accumulated in uraemia which interact negatively with biologic functions of the organism [47]. Three major groups of substances can be distinguished in the UTs spectrum: free water-soluble low molecular weight molecules (LMWM) $(<0.5 \mathrm{kDa})$, middle molecules (0.5-60 kDa) and protein-bound UTs (PBUT) (Table 2). As of April 2021, the European 
Uremic Toxins (EUTox) Database [45] lists 130 substances based on 442 source publications and includes their serum concentrations in uraemia in comparison to healthy individuals. It must be noted that such basic small solutes as urea and creatinine are excluded from this classification and it is controversial whether they should be regarded as toxic per se $[47,48]$.

Table 2. Examples of UT according to the EUTOX database [45]. Asterisk marks substances linked to CKD-aI based on the available literature.

\begin{tabular}{|c|c|}
\hline Substance Groups & Major Examples of UT \\
\hline Free water-soluble low molecular weight molecules (LMWM) & $\begin{array}{l}\text { Uric acid (UA) }{ }^{*} \text {, asymmetric dimethylarginine (ADMA), } \\
\text { malondialdehyde, neopterin, } \\
\text { N-methyl-2-pyridone-5-carboxamide, } \\
\text { N-methyl-4-pyridone-3-carboxamide }\end{array}$ \\
\hline Middle molecules (MM) & $\begin{array}{l}\beta_{2} \text {-Microglobulin } *\left(\beta_{2}-\mathrm{M}\right) \text {, parathormone } *(\mathrm{PTH}) \text {, interleukin-6 } \\
*(\mathrm{IL}-6) \text {, leptin, cystatin } \mathrm{C} \text {, met-enkephalin }{ }^{*}, \beta \text {-dynorphin }{ }^{*}\end{array}$ \\
\hline Protein-bound uraemic toxins (PBUT) & $\begin{array}{l}\text { Indoxyl sulfate } *(\mathrm{IS}), p \text {-cresyl sulfate * }(\mathrm{pCS}) \text {, homocysteine, } \\
\text { carboxymethyllysine, hippuric acid }\end{array}$ \\
\hline
\end{tabular}

It is crucial to acknowledge that the vast majority of data on UT refers to adult population with CKD. As emphasized by Belgian experts in the field [49], publications strictly focusing on paediatric CKD patients are lacking, while the available knowledge regarding the adults may not be fully translated to younger individuals. Therein, the authors mentioned several relevant disparities between paediatric and adult population, mainly larger body water volume and lower circulating proteins, different dietary needs and intake, the ongoing and unfinished processes of maturation and growth, distinct aetiology of CKD, and relatively longer survival when compared to adults with ESRD. Fortunately, as of 2021, new valuable contributions on paediatric CKD and UTs in particular have already been published [50-56].

\subsubsection{Free Water-Soluble Low Molecular Weight Molecules (LMWM)}

Low molecular weight molecules (LMWM) are water soluble substances which do not bind to proteins [57]. In comparison to MM and PBUT, they are easily cleared through dialysis membranes. Therefore, patients with ESRD undergoing HD or PD are less likely to accumulate LMWM. Nevertheless, at least one compound in this group was linked to the development of CKD-aI, although any potential direct causal relationship is debatable. Uric acid (UA) is an organic substance which arises as an oxidation end-product of purine metabolism in humans and higher primates. UA is mainly excreted via urine $(70 \%)$, while gastroenteric elimination accounts for the remaining fraction [58]. Increased UA levels contributed to the risk of CKD disease progression and mortality in adults [59,60]. Similarly, hyperuricaemia was associated with hypertension and CKD progression in children [61]. In a study involving 320 adult patients with CKD (stages 1-5) it was noted that elevated UA levels favoured the development of pruritus in the course of $\operatorname{ESRD~}(p=0.002)$ [62]. However, Solak et al. [30] evaluated 402 patients with predialysis CKD (stages 2-5) and observed no correlation between UA concentration and the occurrence of pruritus $(p=0.133)$. Moreover, no relation between UA concentration and pruritus was determined in ESRD patients undergoing $\operatorname{HD}(n=83)$ [63].

\subsubsection{Medium Molecules (MM)}

The majority of MM are peptides and proteins which weigh between 0.5 and $60 \mathrm{kDa}$, with the latter value also constituting the threshold for the glomerular basement membrane filtration [64]. If the dialyser pore is not big enough, the removal of these substances is difficult to obtain during dialysis. Interestingly, with regard to MM and LMWM removal, haemodiafiltration (HDF) proved more effective than HD [47]. According to Chmielewski et al. [64], the spectrum of MM encompasses adipokines, advanced glycation 
end products (AGEs), appetite regulators, natriuretic peptides, $\beta_{2}$-microglobulin $\left(\beta_{2}-\mathrm{M}\right)$, complement factor D, cystatin C, endothelin-1, free immunoglobulin light chains, interleukins (IL), parathyroid hormone (PTH), fibroblast growth factor-23 (FGF-23), pentraxin-3, prolactin and retinol-binding protein (RBP).

\section{$\beta_{2}$-Microglobulin $\left(\beta_{2}-\mathrm{M}\right)$}

$\beta_{2}-\mathrm{M}$ is a $11.8 \mathrm{kDa}$ polypeptide forming $\beta$ chain of the human leukocyte antigen (HLA) class I molecule, thereby participating in antigen presentation to CD8 lymphocytes $[65,66]$. Its retention in the course of advanced stages of CKD was associated with amyloidosis, malnutrition-inflammation and atherosclerosis syndrome, cardiovascular disease and mortality [67-72]. As reviewed by Argyropoulos et al. [73], despite the conflicting data on the usefulness of $\beta_{2}-\mathrm{M}$ in determining GFR in children, the fractional excretion of $\beta_{2}-\mathrm{M}$ might still play a role in the diagnosis of tubulo-interstitial diseases in this population. Several studies focusing on CKD-aI in adults assessed its relationship with $\beta_{2}-\mathrm{M}$ concentration. Narita et al. [74] evaluated 1773 patients on maintenance HD suffering from CDK-aI, among whom 473 reported severe pruritus (at least 7 points according to the Visual Analogue Scale [VAS]). Higher $\beta_{2}-\mathrm{M}$ concentrations were associated with increased risk of severe pruritus ( $p=0.0006$ compared to groups with mild or moderate pruritus). Moreover, the occurrence of severe pruritus was associated with increased mortality, whereas low $\beta_{2}-\mathrm{M}$ concentrations seemed to play protective role. The authors hypothesized that increased $\beta_{2}-\mathrm{M}$ concentration might stimulate production or accumulation of IL-2 or TNF- $\alpha$, with subsequent activation of CD4 lymphocytes, thereby increasing the risk of pruritus. In a study by Chen et al. [75] $(n=116)$, high-permeability HD proved more effective than conventional HD in reducing CKD-aI intensity, as well as resulting in lower $\beta_{2}-\mathrm{M}$ concentrations. Conversely, in a study by Melo et al. [76] no differences were noted in the concentrations of $\beta_{2}-\mathrm{M}$ when comparing $101 \mathrm{HD}$ patients with and without pruritus. Despite the fact that skin deposits of $\beta_{2}$-M have been found in individuals undergoing dialysis [77], there is no definite proof that this could directly stimulate pruritus. Nevertheless, a study on mice exhibited dose-dependent scratching behaviour following intradermal injection of $\beta_{2}-\mathrm{M}[78]$.

\section{Parathyroid Hormone (PTH)}

PTH is the major product of chief cells in parathyroid glands, with its initial form containing 115 amino acids and termed preproPTH. The active form of the hormone contains 84 amino acids $\left(\mathrm{PTH}_{(1-84)}\right.$, also termed intact $\left.\mathrm{PTH}[\mathrm{iPTH}]\right)$ and exerts its effects through specific G-coupled receptors (PTH1R) [79]. PTH is a crucial factor regulating calcium and phosphate homeostasis in the organism, influencing bones, kidneys and gastrointestinal tract [80]. PTH stimulates $\mathrm{Ca}^{2+}$ release to the extracellular fluid, influences osteoblasts and osteoclasts in the bones, promotes renal reabsorption of calcium and inhibits reabsorption of phosphate. It also stimulates the synthesis of $1 \alpha$-hydroxylase, which is an enzyme necessary in the synthesis of the biologically active form of vitamin $D_{3}$. In the setting of $\mathrm{CKD}$, hyperphosphataemia, hypocalcaemia and decreased concentration of vitamin $\mathrm{D}_{3}$ result in chronic hyperstimulation of parathyroid glands. This perpetuates their increased growth (initially diffuse, then glandular), PTH secretion and release, thereby developing secondary hyperparathyroidism [81]. PTH and FGF-23 are relevant compounds involved in the pathogenesis of CKD mineral and bone disorder (CKD-MBD) in children, influencing bone turnover, mineralization, volume, linear growth, structure and strength, as well as contributing to vascular calcification [82]. Certain data suggest that PTH is another UT possibly contributing to the development of CKD-aI. In 1968, Massry et al. [83] reported on 7 patients with the coexistence of ESRD, secondary hyperparathyroidism and severe intractable pruritus who underwent subtotal parathyroidectomy. Within $48 \mathrm{~h}$ of the procedure, pruritus completely disappeared in 5 patients, with the remaining 2 patients experiencing its disappearance within a week. Similar outcomes were reported by Chou et al. [84] $(n=37)$, although the authors found no correlation between iPTH concentration and pruritus, with 
its postoperative severity positively correlating with calcium phosphorus product $(\mathrm{Ca} \times \mathrm{P})$. Other studies brought conflicting results, with some demonstrating possible correlation between serum iPTH concentration and pruritus $[74,85,86]$, while others refuted this hypothesis [30,63,87-89]. Notably, a study by Senturk et al. [42] conducted among 27 children on PD demonstrated higher serum PTH concentrations among pruritic subjects $(p=0.03)$, similarly to phosphorus, CRP levels and Ca $\times \mathrm{P}(p=0.027 ; 0.026 ; p=0.031$; respectively). These factors were also independently associated with pruritus in a stepwise logistic regression model. The exact pathogenetic mechanisms linking PTH and CKD-aI are unknown; interestingly, Ståhle-Bäckdahl et al. [90] injected PTH intradermally in healthy controls and patients on HD, with no pruritic response in both groups. Moreover, histochemical analysis of skin biopsies taken from patients on HD was consistently negative for PTH. Possibly, the association of PTH with CKD-aI might be expressed indirectly through the influence on calcium homeostasis. Consequently, several studies revealed that increased levels of serum calcium favoured the occurrence of severe CKD-aI [63,74,89], whereas Momose et al. [91] observed increased calcium concentration in the deepest layers of the epidermis of patients with CKD-aI. This may predispose to degranulation and release of various pruritogenic mediators from mastocytes (MCs) and other cells present in the skin.

Interleukin-6 (IL-6)

IL-6 is a glycosylated protein weighing $21-28 \mathrm{kDa}$ and consisting of 4 long $\alpha$-helices [92], similarly to other cytokines from the family (e.g., IL-11, IL-27, leukaemia inhibitory factor, oncostatin M). These cytokines share a common pathway of signaling through receptor unit glycoprotein gp130 [93]. Classic IL-6 signaling occurs when the cytokine interacts with a specific membrane bound receptor (IL-6R) which is present on hepatocytes, megakaryocytes and leukocytes, followed by formation of IL-6R complex with gp130 homodimer [94]. Although many cells do not have membrane bound IL-6R, they may still be involved in the so-called trans-signaling process which occurs due to interaction between IL-6, soluble IL-6R (sIL-6R) and gp130, as the latter is ubiquitous. In short, IL-6 has been attributed to a variety of biological effects, mainly acute phase inflammatory responses, stimulation of lymphocytes, as well as regulation of glucose metabolism and hypothalamic-pituitary-adrenal (HPA) axis [95]. There is a wide range of publications linking IL-6 and disease-related pathogenesis, for example regarding CKD and ESRD. Higher levels of proinflammatory cytokines, including IL-6, were associated with worse renal function during CKD [96] and its rapid progression [97]. Moreover, IL-6 levels were proven factor predicting mortality in patients with ESRD who initiated dialysis $[98,99]$. Following RTx, patients with ESRD experienced swift decline of serum IL-6 concentration [100]. In children suffering from CKD, the development of anaemia was inversely correlated with IL-6 concentration [101]. Additionally, IL-6 predicted acute malnutrition and growth impairment among children and adolescents with CKD [102]. Certain studies revealed a possible link between IL-6 and pruritus occurrence due to chronic sulphur mustard exposure [103] and in the course of prurigo nodularis (PN) [104]. Kimmel et al. [105] reported a correlation between serum IL-6 concentration and the presence of pruritus among 171 individuals undergoing HD $(p=0.019)$, although there was no correlation between IL-6 and pruritus severity. Similar results were obtained by German investigators $(n=39$ ESRD patients on HD) who also observed associations between IL-6 and impaired mental well-being [106]. It must be noted that certain data in the literature link IL-6 and other inflammatory cytokines to depression, including patients on HD $[107,108]$. Concurrently, the presence depression in patients on $\mathrm{HD}$ is a predictor of future CKD-aI occurrence [109], whereas the coexistence of depressive symptoms in paediatric CKD population does occur in practice $[110,111]$.

\subsubsection{Protein-Bound Uraemic Toxins (PBUT)}

In the last decade, PBUT have finally started to gain more scientific attention as substances interfering with essential biochemical functions of the individuals affected with advanced stages of CKD [112]. PBUT are chemicals which circulate in blood in a certain 
equilibrium between free and protein-bound form [113]. While a significant fraction of a solute is protein-bound, the remainder can be removed both by glomerular filtration and tubular secretion [114]. Additionally, if a potentially toxic solute is bound to proteins, its active free form has lower concentration in the circulation and thus the detrimental biological effect is less pronounced. However, in the setting of ESRD, significant protein binding also leads to a major decrease of solute clearance through dialysis [113]. As reviewed in details by Rysz et al. [115], it is the intestinal microbiome which is crucial in the generation of various UT. Essentially, CKD is associated with upregulation of bacteria possessing certain enzymes (such as urease, uricase, tryptophanase), resulting in the generation of UT, whereas concurrent downregulation of bacteria with beneficial properties (such as those producing short chain fatty acids) plays a role as well. Gryp et al. [116] demonstrated lower abundance of Streptococcus spp. and increased abundance of E. coli when comparing CKD patients to healthy controls. Among the whole spectrum of PBUT, there are compounds which have been recently explored to a larger extent in the context of CKD and its various complications. Indoxyl sulfate (IS) and p-cresyl sulfate (pCS) are one of the first PBUT representatives to be identified and are commonly mentioned together in the CKD literature [114]. It must be noted that their chemical structures differ, as they belong to indoles and phenols, respectively [47]. Nevertheless, regarding the abundant similarities, the origins of both substances stem from intestinal microbiota, their precursors are conjugated with sulfates, and they are produced in relatively large quantities. Lin et al. [117] reported a linear correlation between the concentration of both compounds during CKD. Moreover, both IS and pCS are bound noncovalently to serum albumin, with the same binding sites $[113,114]$. In paediatric patients suffering from CKD, the concentrations of IS and pCS poorly correlated with GFR estimated by modified Schwartz formula [51]. Lastly, their contribution to the progression of CKD and its wide range of severe complications is significant (including, among others, CKD-aI), as reviewed in subsequent paragraphs.

Indoxyl Sulfate (IS)

IS has a molecular weight of $213 \mathrm{~g} / \mathrm{mol}$, with a large fraction bound to albumins (90\%) [118]. In short, the generation of IS is initiated when dietary tryptophan reaches colon. Next, resident microbes transform this amino acid into indole, which is then absorbed into the bloodstream. Indole is conjugated with sulfates in liver, forming IS. It was determined that patients with advanced hepatic cirrhosis coexisting with CKD exhibited relatively lower concentrations of IS and pCS [119]. The elimination of IS takes place in proximal tubules of the kidneys which are rich in organic anion transporters (OAT1, OAT3) [120]. The latter are multispecific protein transporters for various toxins, nutrients and drugs. Finally, IS reaches the tubular lumen through apical membrane transporters (multidrug resistance protein 4 [MRP4] and breast cancer resistance protein [BCRP]), and a free molecule is secreted to urine [118]. In a study on children with CKD, IS was one of the PBUT accumulating already in early stages of the disease (CKD stages 1 and 2; median concentrations 1.9 higher than in healthy children; $p<0.05$ ) [50]. IS has a wide range of biological effects in various cells and organs and its nephrotoxic effects arise due to several mechanisms. IS promotes glomerular fibrosis [121] through the activation of transforming growth factor- $\beta 1$ (TGF- $\beta 1$ ), tissue inhibitor of metalloproteinase-1 (TIMP-1) and pro- $\alpha-1$ (I)collagen [122]. Stimulation of p53 protein contributes to senescence and dysfunction of proximal tubular cells, possibly through the activation of $\beta$-galactosidase and $\alpha$-smooth muscle actin ( $\alpha$-SMA) [123], whereas induction of cyclooxygenase-2 (COX-2) by IS results in proliferation of mesangial cells [124]. IS stimulates oxidative stress [125-128], whereby contributing to endothelial senescence [129]. Several studies focused on proinflammatory properties of IS $[130,131]$ and its influence on the function of macrophages [132-134], with the latter aspect linking IS to the development of atherosclerosis. Clinical studies in adult people constituted IS as an important compound related to the progression of CKD, associated CVD, infections, glucose intolerance and mortality [117,135-140]. Similarly, 
recent studies in paediatric patients with CKD reported that serum IS concentrations could be associated with lower residual urine volume, faster progression of CKD, coexistence with CVD and increased mortality $[52,54,55]$.

p-Cresyl Sulfate (pCS)

As for pCS, this compound weighs approximately $188 \mathrm{~g} / \mathrm{mol}$ and binds to serum albumin in 90-98\% [114]. Beginning with tyrosine, this amino acid is transformed into $p$-cresol by microbiota present in colon. Next, aryl sulfotransferases present in the gut mucosa and liver transform $p$-cresol into pCS [141]. A fraction of $p$-cresol is also subjected to glucuronide conjugation and $p$-cresyl glucuronide (pCG) is created. Despite the predilection of $p$-cresol transformed into pCS, the homeostasis in patients with advanced CKD is relatively shifted from pCS to pCG [142]. Similarly to IS, the urinary excretion of pCS is based mostly on tubular secretion through OAT1, OAT3, BCRP and MRP4; with a possible role of organic anion transporting polypeptide 4C1 (OATP4C1) [143]. According to a study by Poesen et al. [143], estimated GFR (eGFR) was a good predictor of pCS and IS clearance during CKD. However, the clearance of pCS was approximately three times lower than for IS, implying different tubular transporter affinities and/or additional transporter systems involved in the process. It was also reported that pCS inhibited MRP4 and BCRP $(40 \%$ and $25 \%$, respectively), while pCG reduced the activity of MRP4 by $70 \%$ [144]. Consequently, this could hamper the transport of other substrates which would exert toxic properties upon their accumulation and additionally perpetuate the progression of CKD. The toxicity of pCS also stems from its ability to enhance NADPH oxidase, whereby stimulating generation of reactive oxygen species and exerting cytotoxic effects on renal tubular cells. Moreover, pCS augmented production of TGF- $\beta 1$, TIMP- 1 and pro- $\alpha 1$ (I)-collagen, which are inflammatory cytokines involved in renal fibrosis [145]. Azevedo et al. [146] reported that pCS induced oxidative burst and phagocytosis in macrophages, whereas there was no change in HLA-DR and CD86 expression. Despite the activation of macrophages, pCS could therefore impede antigen processing and diminish adaptive immune response. Studies on mice revealed increased risk of insulin resistance and detrimental effects on osteoblasts after pCS administration [147,148]. Rossi et al. [149] determined the correlation between pCS (free and total) and IL-6 concentrations in patients with CKD (stages 3 and 4). The association between increased pCS concentration and arterial stiffness (assessed by pulse wave velocity) was also noted $[149,150]$. In patients with CKD (stages 3-5, not yet on dialysis) elevated pCS concentrations were associated with cardiovascular events and dialysis during a 3-year follow-up [151]. Higher concentrations of free pCS were also associated with mortality in several studies, especially in patients on HD [152-154]. Unlike IS, pCS concentrations in children with CKD did not correlate with CVD or CKD progression $[54,55]$. Additionally, pCS was elevated only in later stages of paediatric CKD when compared to healthy controls [50].

\section{PBUT and Their Role in Eliciting CKD-aI}

To date there is a scarcity of data linking PBUT and CKD-aI. Nonetheless, in view of recent publications reviewed below it seems that this topic should be explored in near future, especially given the developing prospects on diminishing PBUT toxicity in CKD. In 2016, Wang et al. [62] published their report on 320 CKD patients (mostly stages 2 and $3)$, among whom $112(35 \%)$ reported pruritus. The latter group had significantly higher total serum concentrations of IS $(p=0.008)$ and pCS $(p<0.0001)$. Although the association between serum IS levels and pruritus disappeared after adjustments for glutamic pyruvic transaminase (GPT) and UA concentrations, pCS maintained its association with pruritus through further adjustments with anthropometric variables, fasting glucose, total cholesterol, GPT, UA, albumin, WBC count, and hs-CRP. The severity of pruritus was also associated with the total pCS concentration $(p=0.0002)$. The authors discussed the possibility of a proinflammatory effect induced by pCS which could account for their findings. However, other investigators did not observe correlations between the concentrations 
of PBUT (IS, pCS, phenyl sulfate and hippuric acid) and severity of pruritus in $135 \mathrm{HD}$ patients [155]. Recently, Kim et al. [156] have performed a complex study providing further insights on PBUT and their association with CI. The cultures of normal human epidermal keratinocytes (NHEK) were exposed to IS, pCS or sera obtained from CKD-aI on HD. Each of these procedures resulted in significant increase of protease-activated receptor-2 (PAR-2) mRNA and protein expression. PAR-2 expression was also more pronounced when comparing skin samples of patients with CKD-aI to healthy controls, as well as mice with CKD to healthy ones. The findings of this study are important due to several reasons. Receptors belonging to PAR family participate in non-histaminergic pruritus, especially in the course of AD [157-159]. Previously, higher protease activity has also been documented in ESRD patients suffering from pruritus $(n=12)$, in contrast to non-pruritic ESRD patients $(n=4)$ and healthy controls $(n=6)$. The expression of PAR-2 has also correlated with pruritus severity [160]. It remains unknown whether this particular pathway could, and to what extent, contribute to the development or exacerbation of CKD-aI in children.

\subsection{Immune Dysfunction}

As reviewed by Cohen [161], the state of uraemia is irreversibly connected to immune dysfunction. Disturbed immune response contributes to the development of CVD and infections, subsequently leading to mortality. Physiologically, kidneys are responsible for clearing bacterial toxins and various endogenous proteins, e.g., cytokines, whereas resident dendritic cells (DCs) participate in maintaining peripheral tolerance [162]. In the setting of CKD these functions become altered; on the other hand, kidneys are also more susceptible to immune-mediated damage themselves. There are multiple immune mechanisms which occur during the course of CKD and concurrently predispose to pruritus. As reported by Kimmel et al. [105], the $\mathrm{Th}_{1} / \mathrm{Th}_{2}$ lymphocytes proportion (assessed both by flow cytometry and the presence of chemokine receptors CXCR3 vs. CCR4) was increased in HD patients suffering from pruritus in comparison to those without this symptom. The authors reported that the concentration of inflammatory biomarkers was also increased (e.g., IL-6; reviewed in subsequent paragraphs). IL-6 is not the only cytokine which could play a role in CKD-aI. Previously, increased IL-2 concentrations have been reported among pruritic subjects with CKD [163]. IL-2 is a cytokine stimulating proliferation and generation of effector and memory T lymphocytes [164]. It exerted pruritic response after intradermal injection in healthy and AD subjects $[165,166]$, whereas it was also more represented in the skin of patients with psoriasis suffering from pruritus [167]. Notably, IL-2 has been utilized therapeutically (e.g., in metastatic renal carcinoma or melanoma), with pruritus not infrequently occurring as an adverse event [168]. Fallahzadeh et al. [163] discussed the possible mechanisms linking IL-2 to CKD-aI and hypothesized that IL-2 may influence central nervous system (CNS), possibly by affecting physiologic functions of neural cells and neurotransmission or interfering with opioid receptors. Another physiological protein (IL-31) has been termed "pruritogenic cytokine" [169], although its effects in terms of inducing pruritus in healthy or atopic subjects are not immediate [170]. Unlike other members of the IL-6 family, it does not interact with gp130. The heterodimeric IL-31 receptor complex (IL-31R) consists of IL-31R $\alpha$ subunit and oncostatin M receptor $\beta$ subunit (OSMR $\beta$ ) [169]. IL-31 is produced mainly by $\mathrm{Th}_{2}$ lymphocytes and mature DCs [171] and exerts its biological effects through Janus-kinase (JAK1/JAK2) and other pathways (reviewed in details by Furue et al. [172]). The association between elevated IL-31 and CKD-aI has already been reported by several investigators [173,174], although the blockade of this pathway by nemolizumab (an anti-IL31 monoclonal antibody) has not provided particularly effective outcomes in a recent phase II study $(n=69)$ [175]. Nevertheless, it seems that overexpressed IL-31 may contribute to CKD-aI through the activation of peripheral sensory nerves [174], as the expression of IL-31R $\alpha$ was documented in a subpopulation of TRPV1+/TRPA1+ neurons of dorsal root ganglia in mice [171]. Another study on mice revealed that IL-31 promotes nerve elongation and branching in vitro and in vivo, which may play a role in pruritus associated with AD [176], possibly in other pruritic conditions with elevated IL-31 levels as well. 
The pathogenetic considerations on CKD-aI are not comprehensive without covering the role of MCs. Classically, MCs were regarded as effectors of early and late phases of allergic reactions [177]. Allergic reactions in type I hypersensitivity are mediated by specific IgE antibodies which stimulate MCs through high-affinity IgE receptors (FC $\varepsilon$ RI). Subsequently, a plethora of mediators are released, resulting in neurogenic inflammation, which also includes wheals, flare, pruritus, oedema and sensitization of peripheral nerve endings [178]. The main pruritogenic mediators released from MCs are histamine, serotonin, tryptase, chymase, IL-31, leukotrienes, prostaglandins and neuropeptides [177,179]. Several studies correlated increased serum levels of histamine [180-182] and serotonin [183] with CKD-aI, whereas other studies were unable to demonstrate such associations [184-186]. Apart from "basic" IgE-related pathway leading to the release of histamine and serotonin from MCs (histaminergic pruritus), recently a new pathway has been discovered [187]. Nonhistaminergic pruritus is elicited when MCs are stimulated by pro-adrenomedullin peptide 9-20 (PAMP 9-20) and compound 48/80, leading to abundant secretion of tryptase. The latter excites sensory nerves possessing receptors belonging to the family of Mas-Related G-Protein-Coupled Receptors (Mrgpr). The importance of tryptase in developing pruritus stems from its ability to cleave and activate PAR-2 receptor on sensory nerves, immune cells and even MCs themselves [179]. In fact, Dugas-Breit et al. [188] reported increased serum levels of tryptase in CKD patients, with CI intensity correlating significantly with tryptase concentration $(p=0.014)$. It is vital that MCs and nerves are in close contact with each other and may even be regarded as a common physiological unit [189]. Several investigators have confirmed the associations between MCs and CKD-aI [190-194], although German investigators reported no relation between the number of MCs present in the skin and the occurrence of pruritus [184]. According to different researchers, MCs were more prevalent in dermis of CKD-aI patients on HD [190-192], but also diffusely spread and highly degranulated [191]. Our group has previously demonstrated higher counts of tryptase- and chymase-positive MCs in HD patients than in healthy controls [193] and their susceptibility to apoptosis following UVB irradiation [194], with the latter findings constituting a rationale to manage CKD-aI with phototherapy.

\subsection{Opioid Transmission}

Opioid system is a physiological component of each organism, with a widespread distribution in both peripheral (PNS) and central nervous system (CNS) [195]. Feng et al. [196] reviewed diverse contributions of opioid system to the well-being of an organism, mainly its participation in ionic homeostasis, cell proliferation, neuroprotection, hibernation, pain modulation, emotional response, immune response, feeding, respiratory control and cardiovascular regulation. Essentially, opioid system is physiologically based on interactions between endogenous ligands and their receptors. The former include Met- and Leu-enkephalin, dynorphins (A and B), neoendorphin and $\beta$-endorphin. These ligands may interact with four major types of transmembrane $G$ protein-coupled receptors: $\mu$ (MOR), k- (KOR), $\delta$ - (DOR) and nociception/orphanin (NOP-R) [197]. The physiological components may be interfered with in the setting of various diseases (e.g., addiction, depression, Alzheimer's disease to name just a few [198-200]), or as a result of iatrogenic intake of opioids. Notably, exogenous opioids lead to numerous adverse effects, including pruritus, which affects $2-10 \%$ of patients following systemic administration [201]. The risk of pruritus is especially high if epidural, intraspinal or intrathecal route is chosen-with the latter, the reported prevalence may reach $100 \%$. The influence of opioid system on the pathogenesis of pruritus is complex. Although certain opioids (e.g., morphine) can induce histamine release, others do not (e.g., fentanyl). Moreover, antihistamines are not effective in managing opioid-induced pruritus [202]. Experiments conducted on monkeys revealed that MOR agonists stimulated pruritic response, whereas MOR antagonists and KOR agonists attenuated pruritus [202-204]. In a recent study, Wang et al. [205] have reported that intrathecal administration of morphine in mice elicited scratching response due to activation of MOR receptors in spinal inhibitory interneurons, which resulted in disinhibition 
of spinal itch circuit. Studies in humans revealed decreased KOR expression in the skin of pruritic patients suffering from psoriasis vulgaris [206,207] and AD [208]. Accordingly, our group has been the first to demonstrate that HD patients suffering from CKD-aI $(n=21)$ had lower expression of KOR receptors than those without pruritus $(n=19 ; p<0.02)$. Additionally, pruritus intensity was also inversely correlated with KOR expression $(r=-0.63$, $p=0.002)$ [209].

It must be noted that a study published already in 1995 assessed the concentration of Met-enkephalin in 21 CKD patients on HD [210]. When compared to healthy controls $(n=10)$, a statistically significant difference in Met-enkephalin concentration was noted $(p<0.01)$. However, the concentration of Met-enkephalin was not correlated with pruritus severity. No further studies on a larger sample of CKD patients have been executed. Interestingly, according to EUTOX database, Met-enkephalin and $\beta$-dynorphin are also listed as UTs from the MM group [45]. Given the mixed results concerning the association of $\beta$-dynorphin with pruritus in the course of various chronic inflammatory dermatoses [211-214], we have therefore decided to re-evaluate the possible role of several UTs, including endogenous opioids, in the context of CKD-aI in adults; as of June 2021, the study is in progress.

\subsection{Infectious Agents}

As mentioned previously, patients with CKD have a higher risk of infections. The impairment of adaptive T-cell responses may predispose to severe viral infections [215]. Based on epidemiological studies encompassing large groups of participants, infections with hepatitis $B$ virus (HBV) and hepatitis $C$ virus (HCV) are statistically related to the presence of CKD in the general population [216,217]. While chronic hepatitis may contribute to the development of CKD and its further progression to ESRD [218-221], patients may also acquire these infections de novo, especially if they are undergoing dialysis [222,223]. Among numerous complications associated with viral hepatitis, pruritus concerns $11-46 \%$ HBV patients and 22-58\% of those with HCV [224-227]. Based on the data gathered from 18,801 patients on HD, it seems that concurrent $\mathrm{HCV}$ infection increases the risk of moderate to extreme pruritus (10\% vs. $8.6 \% ; p=0.006)$ [22]. Abdelsalam et al. [228] have also demonstrated significantly higher pruritus severity among 193 HD patients with concomitant active HCV infection $(p=0.009)$. Interestingly, a Peruvian study has reported a decreased risk of severe pruritus with the coexistence of hepatitis $C$ ( $n=264$ ESRD patients) [229]. As reviewed by Alhmada et al. [230], the mechanisms linking HCV to pruritus involve the occurrence cholestasis and induction of interferon-stimulated genes, whereas the main pruritic mediators include cytokines and chemokines (e.g., IL-8, CCL2, CXCL1, CXCL5). We were unable to find any studies which assessed pruritus prevalence and its severity among children suffering both from CKD and viral hepatitis. Due to the common practice of anti-HBV vaccination in developed countries and based on the studies on adults, the potential role of HCV seems more substantiated.

In 1985, Lempert et al. [231] used the term "pseudouremic pruritus" to elegantly illustrate a scabies outbreak in a dialysis unit in West Virginia, USA. Although we have never encountered similar situation in Poland, this report highlights that the presence of pruritus in a patient with CKD can also occur due to other causes. If scabies is not recognized and properly treated, intense and often generalized pruritus may bother the affected patient for weeks or months, fulfilling the criteria of CI, but wrongly attributed only to the underlying CKD or associated drug use. Notably, pruritus associated with scabies, as well as CKD-aI, frequently exacerbates at night. A recent onset of pruritus in a patient diagnosed with CKD may denote natural disease progression or an infestation with scabies, which is regarded as a "great mimicker", occasionally tricking even experienced dermatologists. On the other hand, Yates et al. [232] have also reviewed the peculiar association between scabies and secondary streptococcal infection, which further predisposes to post-streptococcal glomerulonephritis (PSGN) and ultimately CKD. 


\subsection{Skin Dryness (Xerosis)}

Xerosis is one of the most frequent dermatological symptoms which occurs in up to $29.4 \%$ of the general adult population [233]. It also constitutes a cardinal feature of atopic dermatitis, with the latter affecting at least $2-10 \%$ of young adults and $20 \%$ of children [234]. Therefore, due to other possible causes, the genuine prevalence of xerosis in children seems to be even higher. Xerosis concerns the majority of patients adult patients suffering from CKD (59.3-93.1\%) [235], especially those undergoing dialysis. To the best of our knowledge, our research group was the first to assess the problem of xerosis among a cohort of CKD children $(n=102)$ [236]. In total, xerosis bothered $54.2 \%$ of patients, whereas in healthy controls it occurred less frequently $(12.9 \% ; p<0.01)$. Regarding the basic CKD treatment approach, xerosis was present in $42.1 \%$ children on conservative treatment and $67.6 \%$ among those undergoing dialysis $(p=0.03)$. The control group presented with xerosis located only on the forearm and the lower legs. In CKD patients these were the most common locations, yet also more commonly involved than in controls; other locations were dry as well (the abdomen and the chest). Xerosis was also associated with the presence of pruritus $(p<0.01$; detailed characteristics of pruritus in this cohort are reviewed in subsequent paragraphs). When comparing CKD patients with healthy controls, epidermal moisture evaluated by corneometry was lower on the lower legs, the abdomen and the chest $(p<0.001$ each). Moreover, transepidermal water loss (TEWL) measured by tewameter was more pronounced in CKD than in healthy controls in certain locations, such as the forearms $(p<0.001)$ and the lower legs $(p=0.04)$. Notably, we noted correlations between xerosis and CKD-aI among children, confirming the results of previous studies conducted among adults [237-239].

The pathogenesis of uraemic xerosis seems multifactorial and the reported data is inconsistent when comparing different studies, especially in terms of xerosis-pruritus associations. Ståhle-Bäckdahl [240] evaluated 19 patients with CKD-aI undergoing HD and 12 healthy controls. There was no significant difference between stratum corneum (SC) water content between both groups. Park et al. [241] revealed decreased water content among patients on HD $(n=18)$ compared to healthy controls $(n=10)$ and decreased sweating response to sudorific agent, whereas there was no correlation between skin surface hydration and pruritus. Yosipovitch et al. [242] reported no influence of xerosis, SC hydration or sweat secretion on the occurrence of CKD-aI $(n=85)$. A Japanese study reported no correlation between pruritus intensity and $\mathrm{SC}$ water content by skin surface hydrometer, both before and after HD session [243]. We have previously evaluated skin hydration and lipid content in 80 ESRD patients on HD and 30 controls, demonstrating similar prevalence of xerosis in both groups ( $50 \%$ vs. $56.2 \% ; p=0.7$ ) [244]. However, xerosis was more common in subjects complaining of pruritus ( $80 \%$ vs. $42 \% ; p=0.002)$. The presence of xerosis contributed to pruritus severity assessed by Visual Analogue Scale (VAS) among HD patients, whereas xerosis intensity demonstrated no such correlation. We have also demonstrated that SC lipid content differed between patients on HD and healthy controls. The former group presented higher content of ceramides 1,2 and $3(p<0.01)$ and lower content of cholesterol and triglycerides $(p<0.01$ each). Mixed results were also reported by Yosipovitch et al. [245], who observed impaired SC integrity in ESRD patients $(n=20)$ vs. healthy controls $(n=18 ; p=0.001)$ and a correlation between decreased glycerol content and xerosis in the arm $(p=0.01)$. Other assessed characteristics of SC (permeability, $\mathrm{pH}$ and ultrastructure) did not differ between the groups. Despite such discrepancies in the pathogenesis, several clinical studies confirmed that emollient therapy ameliorates not only uraemic xerosis, but also CKD-aI [239,246,247].

\subsection{Neuropathy}

According to the statement "it is the brain that itches, not the skin", the role of PNS and CNS in the generation of CI remains vital [248]. Essentially, CKD-aI is classified in the category of systemic causes of pruritus (III) according to IFSI classification, while "pure" neuropathic pruritus of central or peripheral origins is classified separately (V) [2]. 
However, certain publications reported that CKD may in fact contribute to neuropathy and possibly predispose to CKD-aI. Regardless, the reported findings seem inconsistent. Using neuron-specific enolase (NSE), Johansson et al. [249] demonstrated that nerve fibers and terminals were sprouting throughout the epidermis of 12 CKD patients on HD, in contrast to healthy controls $(n=15)$. However, there were no differences between patients suffering from pruritus and those free from this sensation. Fantini et al. [250] observed a reduction in the total number of nerve terminals in the skin when comparing 24 patients with CKD and 10 healthy subjects, although no correlations with pruritus were found. Zakrzewska-Pniewska et al. [251] reported that pruritus occurred among 32 of 51 ESRD patients on dialysis, with a higher severity of pruritus among individuals bothered by paraesthesia $(p<0.01)$. The signs of autonomic neuropathy did not correlate with pruritus. Papoiu et al. [252] conducted a functional magnetic resonance imaging (fMRI) of the brain in 13 ESRD patients on HD suffering from CI, revealing regional differences in grey matter density when compared to 15 healthy controls. Regional differences in brain perfusion were noted as well (detailed results therein).

To the best of our knowledge, there is a lack of data linking paediatric CKD, neuropathy and CI. Young patients with CKD may also suffer from peripheral neuropathy in up to $52 \%$, although studies revealed a relative predominance of motor neuropathy over sensory $[253,254]$. Therefore, the hypothetic association with CKD-aI seems uncertain at most. In another study, multifocal white matter injury upon brain MRI scans concerned six out of twenty-nine children suffering from CKD (stages 4 and 5) [255]. Hartung et al. [256] reported several differences in grey and white matter volumes between young CKD patients $(n=85)$ and healthy controls $(n=63)$. Nevertheless, neurocognitive assessments demonstrated no differences in relation to regional brain volumes.

\subsection{Dialysis Modality and Its Parameters}

Along with the progression of CKD to ESRD, a patient is inevitably faced with a near prospect of dialysis or RTx. Various dialysis modalities may be considered as a crucial therapeutic intervention to decrease the bothersome signs and symptoms of CKD. However, regarding certain CKD manifestations, dialysis may also paradoxically contribute to their development and/or exacerbation. Accounting for the heterogeneity of available systems it is substantiated that the major differences regarding dialysis methods and parameters could exert influence on CKD-aI in a positive or negative direction. Historically, the initiation of HD in 1960s seems to have contributed to the increased prevalence of CKD-aI [257]. Early in 1970 s the prevalence of CKD-aI reached $85 \%$, further decreasing to $50-60 \%$ in the late 1980s [258]. Two decades ago our group evaluated 130 patients on HD, among whom $40.8 \%$ complained of CDK-aI [238]. There was a significant positive correlation between pruritus severity and duration of the HD period $(p<0.02)$. Patients undergoing dialysis on polysulphone membranes reported pruritus more commonly $(57.9 \%)$ than on hemophane $(30.8 \% ; p<0.04)$ or cuprophane $(34.8 \% ; p<0.03)$ membranes. Aucella et al. [259] advocated the usage of polymethylmethacrylate (PMMA) membranes over standard lowflux synthetic membranes to diminish CKD-aI $(n=8)$. Chen et al. [75] demonstrated better effectiveness of high-permeability HD than conventional HD in terms of reducing CKD-aI intensity $(n=116)$. A randomized controlled trial (RCT) by Jiang et al. [260] revealed superiority of high-flux HD (HFHD) $(n=27)$ over HDF $(n=24)$ in reducing CKD-aI severity. At week 12, patients on HFHD experienced more significant reduction in mean VAS pruritus score $(9.0 \pm 1.8$ points to $1.8 \pm 0.4$ points) than those on $\operatorname{HDF}(8.8 \pm 1.6$ points to $3.2 \pm 0.8$ points). Similarly, Ko et al. [261] reported that CKD-aI aggravation may be associated with low-flux HD $(n=111)$. Moreover, publications on dialysis patients consistently mention $\mathrm{Kt} / \mathrm{V}$ value. This parameter was introduced over 30 years ago and refers to "dialyzer clearance of urea multiplied by dialysis time and normalized for urea distribution volume", as reviewed by Vanholder et al. [262]. Kt/V value was also assessed in several studies focusing on CKD-aI, providing inconsistent results. For example, Zucker et al. [263] and Chen et al. [75] found no correlation between this parameter and 
CKD-aI occurrence and severity. Zucker et al. [263] emphasized that Kt/V value essentially denotes the clearance of LMWM, while the removal of MM and large molecules cannot be quantified this way. Therefore, even seemingly high $\mathrm{Kt} / \mathrm{V}$ value does not necessarily prevent the accumulation of other UT which can theoretically predispose to CI. Still, the associations between $\mathrm{Kt} / \mathrm{V}$ value and $\mathrm{CKD}$-aI were in fact demonstrated in other papers $[89,261,264]$. One study reported the threshold $\mathrm{Kt} / \mathrm{V}$ value of 1.5 , with higher values favouring lower intensity of CKD-aI [261]. It is unknown if the observations on $\mathrm{Kt} / \mathrm{V}$ values in adult patients with CKD-aI can be extrapolated to children with this symptom. Nevertheless, there is a plethora of evidence that the usage of $\mathrm{Kt} / \mathrm{V}$ value as a dialysis adequacy marker must be carefully adjusted in a paediatric setting [265].

\subsection{Other Factors}

\subsubsection{Vitamin A}

The rationale for investigating vitamin $A$ in the context of CKD-aI stems from the observation that certain signs and symptoms of hypervitaminosis A (xerosis, pruritus) are also relatively common in CKD [266]. As reported by de Kroes and Smeenk [267], CKD patients had elevated serum vitamin A levels $(n=25)$. However, no correlation was found between vitamin A concentration and the presence of CKD-aI. Berne et al. [266] determined elevated retinol content in epidermis and serum of patients with CKD-aI $(n=10)$ when compared to controls $(n=5)$. After performing a whole-body phototherapy (UVA + UVB), pruritus disappeared in seven patients. Concurrently, epidermal content of retinol was reduced as well, whereas its serum concentration was not influenced by phototherapy.

\subsubsection{Aluminium $(\mathrm{Al})$}

CKD patients may be subjected to increased exposure to aluminium (Al) due to different causes. Several decades ago, the main reasons included the contamination of the water used as a dialysate solution and the usage of phosphate binders [268]. Accumulation of $\mathrm{Al}$ predisposes to several complications of CKD, e.g., osteodystrophy, anaemia and encephalopathy [269]. Friga et al. [270] reported that elevated Al levels correlated both with CKD-aI occurrence $(p=0.008)$ and its intensity $(p=0.007)(n=94)$. In a recent study $(n=866)$, Hsu et al. [268] revealed significant correlations between increased $\mathrm{Al}$ concentration in serum and CKD-aI. Moreover, each tenfold increase in serum Al concentration led to a 5.64 times higher risk of CKD-aI.

\subsubsection{Air Pollution}

The magnitude of air pollution is constantly expanding in different regions of the world. Given the multifactorial nature of $\mathrm{CI}$, it is worth exploring whether environmental factors actually contribute to its presence or intensity. Over the past decade, the associations between $\mathrm{CI}$ and air pollution have been explored in the context of children with AD [271-273]. As reported by Whang et al. [274], internet search queries for the word "itch" in fact correlated with the concurrent concentration of atmospheric particulate matter $<2.5 \mu \mathrm{m}$ (PM 2.5). Interestingly, chronic exposure to air pollutants have already been linked to the presence of CKD-aI in Taiwanese patients on $\mathrm{HD}(n=866)$. The mean concentrations of nitric dioxide $\left(\mathrm{NO}_{2}\right)$ and carbon monoxide $(\mathrm{CO})$ during the previous 12 months correlated with the presence of CKD-aI ( $p<0.001 ; p=0.007$; respectively) [275]. Additionally, increased concentrations of PM 2.5 for more than 116 days during the previous 12 months were also associated with CKD-aI (OR 3.57; $p<0.001$ ) [276]. The authors summarized the possible pathogenetic mechanisms of their findings, including the stimulation of oxidative stress, skin barrier disruption, increased number of epidermal nerve fibers, immune dysfunction and neurogenic inflammation $[275,276]$.

\subsubsection{Protective Role of Loop Diuretics}

In 2017, Hayani et al. [277] reported that the intake of loop diuretics (furosemide or torasemide) during previous 12 months was associated with a significantly lower 
risk of pruritus among over 800 adult CKD patients on HD (25\% vs. $15 \% ; p<0.001)$. Logistic regression analysis revealed adjusted odds ratio (aOR) of 0.622 for the current presence of pruritus (95\% confidence interval $0.412-0.938 ; p=0.024)$. The authors suggested several possible explanations for these observations, such as preservation of residual kidney function (RKF), anti-inflammatory effects of diuretics and binding to NKCCK ion channels. Cautious interpretation is warranted, especially in terms of potential direct causal relationship between loop diuretics and CKD-aI. Nevertheless, we deem these unexpected findings especially interesting as furosemide is one of the few drugs which are both officially registered for use in paediatric population and well-studied in clinical practice.

\section{Epidemiology and Clinical Picture of CKD-aI in Children}

Based on our literature search, Silverberg et al. [39] were the first authors to report on the subject of CKD-aI in children. Their study focused on cutaneous manifestations in 30 children of colour who suffered from chronic renal failure. The analysed group consisted of 10 children after RTx, 16 on dialysis and four managed with pharmacotherapy. All patients presented with skin conditions, especially xerosis, which bothered $86.7 \%$. Pruritus was the second most common complaint, affecting 17 patients (56.7\%). Regarding the subgroups, pruritus was reported by $25 \%$ in the conservative treatment, $69 \%$ in the dialysis and $50 \%$ in the transplant group. As stated by the authors, "xerosis was often accompanied by pruritus", although a small number of participants precludes drawing definite conclusions. In 2002, Mettang et al. [40] published an editorial comment on CKD-aI. Therein, they recounted German data on 199 children and 505 adults on HD. CDK-aI was present in 9.1\% and $18.8 \%$ patients, respectively $(p=0.0013)$. It was mentioned that "the intensity was not very severe in the affected patients", although no further details were provided. The authors suggested these differences may be explained by a higher $\mathrm{Th}_{1}$ lymphocyte differentiation occurring in the course of aging. Subsequently, Turkish investigators [42] reported on 27 paediatric patients (aged 5-18 years) undergoing PD for at least 6 months. CKD-aI bothered 6 children $(22.2 \%)$ among whom four were girls. Pruritus intensity according to VAS was very low (mean 1.33 points), ranging between 1-2 points. Gradual onset of pruritus was reported by four patients, whereas sudden by two. Pruritus was localized in five children; none of the pruritic patients provided any data on the factors aggravating the sensation, whereas all of them reported intermittent characteristics of pruritus. Interestingly, certain laboratory parameters were correlated with pruritus: serum phosphorus $(p=0.027)$, $\mathrm{Ca} \times \mathrm{P}(p=0.031), \mathrm{PTH}(p=0.03)$ and CRP $(p=0.026)$. Another study on cutaneous disorders associated with uraemia included 43 children on HD and 38 healthy controls [43]. Xerosis was the most common symptom (53.5\%), followed by pallor and pruritus (18.6\% each). However, there was no difference in pruritus prevalence between uraemic subjects and controls $(p=0.606)$.

In 2016, our group published results on pruritus among Polish children suffering from CKD (stages 3-5) [44]. The study group consisted of 34 subjects on dialysis (20 HD, 14 PD), 38 subjects on conservative treatment and 31 controls. Overall, CKD-aI concerned 20.8\% CKD patients $(n=15)$, with the mean pruritus intensity (assessed by VAS; patients were asked to determine maximal intensity within previous $24 \mathrm{~h}$ ) of approximately 3.5 points. The chosen method of treatment did not influence pruritus severity, duration or location. Notably, generalized pruritus was more common in patients on dialysis than on conservative treatment $(87.5$ vs. $28.6 \% ; p=0.02)$. Children with CKD-aI had significantly lower eGFR (median 13.2 vs. $21.0 \mathrm{~mL} / \mathrm{min} ; p=0.03)$, higher $\mathrm{Ca} \times \mathrm{P}(p=0.015)$ and more frequently exhibited xerosis $(66.7$ vs. $50.9 \% ; p<0.01)$. Among the group of patients with CKD, those suffering from pruritus were also more prone to develop lower leg xerosis $(60.0 \%$ vs. $21.1 \% ; p<0.01)$. We emphasize the difficulties in conducting studies in children with CI. Due to potential heterogeneity of age, especially the youngest respondents may not adequately express their sensations on itch intensity. A fraction of the data may therefore be obtained from parents/caregivers, or, based on scratching activity, assessed indirectly during the interview or sleep. Additionally, scratching leads to secondary skin lesions, 
e.g., excoriations, erosions, crusts, and skin infections. More chronic scratching leads to hypo- and hyperpigmentation, scarring and PN. We were unable to find any papers on the latter in children suffering from CKD; we speculate that CKD-aI intensity in paediatric population is generally too low to result in such outcome.

\section{Management of CKD-aI in Children}

Given the paucity of reports focusing on CKD-aI in paediatric population, its treatment may be regarded, without any overstatement, as terra incognita. Still, in subsequent paragraphs we have provided recommendations on the management of paediatric CKD-aI based on the available literature evidence on CKD-aI treatment in adults as well as CI treatment in children in general (Table 3). Taking into consideration the growing knowledge on UTs (especially PBUT) and strategies attempting to minimize their detrimental effects in CKD patients, we have also reviewed these aspects in terms of possible alleviation of CKD-aI in children. However, based on the current IFSI guidelines [1] it is vital to inform the parents / caregivers of a child suffering from CI about basic recommendations which are universal and in fact constitute the first therapeutic step. These include soft and permeable clothing (e.g., cotton), usage of non-alkaline soaps or syndets (synthetic detergents), short bathing in luke-warm water and avoidance of vigorous skin rubbing with towels after bath. Concurrently, patients should avoid any activity which predisposes to xerosis, such as too frequent and too long bathing, dry climate or alcohol compresses. Dietary aspects should also be discussed, with the intake of hot and spicy foods, hot drinks or alcohol firmly discouraged. Psychological factors such as excitement, strain or negative stress can also exacerbate CI. Therefore, relaxation techniques and education are also of benefit. To enhance patient's compliance, all recommendations should also be provided in a written manner.

Table 3. Treatment modalities of possible usage in children with CKD-aI.

\begin{tabular}{cr}
\hline Therapeutic Group & Examples of Treatment \\
\hline Topical therapy & Emollients \\
\hline Phototherapy & NB-UVB \\
\hline Systemic therapy & $\mathrm{H}_{1}$-antihistamines, gabapentin, pregabalin, ondansetron, activated charcoal \\
\hline Targeting PBUT & Reducing production: proper protein intake, fibre intake, probiotics, prebiotics, synbiotics, laxatives \\
\cline { 2 - 2 } & Decreasing intestinal absorption: activated charcoal, AST-120 \\
\cline { 2 - 2 } & Increasing removal: preserving kidney function, improving dialysis, RTx \\
\hline
\end{tabular}

\subsection{Topical Therapy}

Regardless of the underlying aetiology of CI, topical therapy remains the mainstay of the treatment due to its safety and versatility. Moreover, taking into account the role of xerosis in developing CKD-aI, we deem emollients the crucial therapeutic step in managing children with this particular condition. The application of emollients results in a thin layer of occlusive lipids which limits TEWL [278]. Due to various ingredients, they replenish skin barrier, decrease inflammation and alleviate CI. The main antipruritic substances present in emollients include urea (5-10\%), glycerol (20\%), camphor $(2 \%)$, menthol (1\%), zinc $(10 \%)$, pramoxine $(1 \%)$ or polidocanol (2-10\%) [1]. Although the cost or the regional unavailability of certain ingredients can be a major obstacle in their preparation, the pharmaceutical composition makes emollients an individually tailored modality, suitable for the needs of each patient. Emollients should be applied frequently (several times a day) and in high quantities. Their application is particularly useful shortly after finishing bath when skin is still moist. Notably, emollients have already proven beneficial in managing CKD-aI in adults. The most relevant studies in this topic assessed $15 \%$ glycerol and $10 \%$ paraffin emulsion [239], 10\% urea and dexapanthenol lotion [279] and 2.2\% gammalinolenic acid cream [280]. Additionally, the use of topical anaesthetics in CKD-aI is also 
supported by clinical studies, e.g., concerning $1 \%$ pramoxine lotion [281] and bath oil containing polidocanol [282]. Our group has also successfully assessed the preparation containing structured natural lipids and endocannabinoids ( $\mathrm{N}$-acetylethanolamine and $\mathrm{N}$-palmitoylethanolamine) in managing CKD-aI [247]. Apart from "pure" moisturizing effect, the mechanism of action may involve interference with histamine release or the activation of MCs.

Capsaicin is also mentioned among topical preparations alleviating CKD-aI [283-285]. This chilli-derived substance exerts its antipruritic properties via depleting substance $P$ (SP) from sensory nerve terminals of the skin [286]. Due to skin-irritating properties, capsaicin preparations should be used cautiously in children. The use of topical calcineurin inhibitors (TCI) in CKD-aI gave mixed results. Two small studies reported improvement after $0.03 \%$ [287] and $0.1 \%$ [288] tacrolimus ointment, whereas a RCT reported no benefits of $0.1 \%$ ointment over placebo [289]. Moreover, $1 \%$ pimecrolimus cream was also ineffective in a RCT [290].

\subsection{Phototherapy}

Phototherapy with either UVA (320-400 nm; mainly as psoralen + UVA [PUVA] therapy) or UVB (290-320 nm) sources constitutes the second step in therapeutic ladder of several chronic inflammatory dermatoses, especially in psoriasis vulgaris and AD [234,291]. The fundamentals accounting for the effectiveness of phototherapy in dermatology are profuse and reflect close associations between the skin and the immune system. Essentially, phototherapy induces cytokine profile changes, apoptosis, immunosuppression and cell cycle arrest [292]. Following narrow-band UVB (NB-UVB; $311 \mathrm{~nm})$ irradiation a threefold increase of $\mathrm{p} 53$ positive keratinocytes was noted, along with twelvefold increase of apoptotic cells and twofold decrease of Langerhans cells [293]. The role of broad-band UVB (BB-UVB) and NB-UVB in stimulating apoptosis of MCs has already been mentioned in previous paragraphs [194]. Other relevant mechanisms of phototherapy involve improved vitamin D status [294], reduced microbial colonization [295], increased production of antimicrobial peptides (AMP), enhancement of skin barrier [296] and influence on cutaneous sensory nerves [297].

Clinical studies on the efficacy of phototherapy in CKD-aI have been conducted since late 1970s. The majority of studies reported favourable outcomes after BB-UVB [298-303]. More recently, NB-UVB has been proven effective in several papers on CDK-aI [304-307], although one case report documented its lack of efficacy (and a better response to BBUVB) [303]. Notably, Ko et al. [308] conducted a RCT comparing NB-UVB $(n=11)$ and placebo (UVA; $n=10$ ), revealing no significant differences regarding pruritus intensity between both groups. Among secondary outcomes, NB-UVB provided significant improvement only in the body surface area affected by itch $(p=0.006)$. In a recent Cochrane systematic review on the management of CKD-aI the authors stated that "UVB radiation may make little or no difference to uraemic itch ( . . . ) compared to UV-A/placebo" [309]. Based on our experiences with NB-UVB in adult CKD-aI patients and in children with various inflammatory dermatoses, we conclude that this modality can be cautiously used in children older than 4 years with CKD-aI not responding to topical therapy.

\subsection{Systemic Therapy}

The instigation of systemic antipruritic therapy in children with CKD-aI or other types of $\mathrm{CI}$ is frequently hindered due to the lack of registration in these indications. Therefore, before starting therapy its off-label nature should be explained to the parents/caregivers of the patient. Potential nephrotoxicity of systemic drugs necessitates strict cooperation with an experienced paediatric nephrologist to prevent further progression of CKD to ESRD and to reduce the risk of other serious adverse events. In patients on dialysis, the dosing regimen should also be adjusted to its schedule, e.g., thrice a week. 


\subsection{1. $\mathrm{H}_{1}$-Antihistamines}

Among systemic drugs diminishing $\mathrm{CI}, \mathrm{H}_{1}$-antihistamines have been used for decades. They are inverse agonists of $\mathrm{H}_{1}$-receptors, preferably binding to the inactive state of the receptor and stabilizing it [310]. First generation of $\mathrm{H}_{1}$-antihistamines encompasses, among others, hydroxyzine, clemastin, doxepin, dimetindene and ketotifen. These drugs are wellstudied in children, although their antipruritic properties are usually small to moderate. The main benefit of first-generation $\mathrm{H}_{1}$-antihistamines includes their ability to cross bloodbrain barrier (BBB) [311]. Although it results in decreased concentration and somnolence, the latter may be desirable in the evening or at night to improve sleep. An experimental study by Kim [312] reported that first-generation $\mathrm{H}_{1}$-antihistamines exert their effects on various subcortical and cortical regions of the brain which results in decreased pleasure associated with scratching. Regarding CKD-aI treatment in adults, the usage of hydroxyzine [313,314], doxepin [315,316] and ketotifen [185,317] is supported by the available literature. Concerning second generation of $\mathrm{H}_{1}$-antihistamines, desloratadine diminished CKD-aI in a prospective, crossover, open-label trial $(n=22)$. Unexpectedly, desloratadine turned out more effective than gabapentin in reducing pruritus intensity according to VAS ( $p=0.004 ; p=0.07$; respectively) [318]. Second-generation $\mathrm{H}_{1}$-antihistamines are hydrophilic, do not cross BBB and are well-tolerated. However, setting aside the treatment of urticaria, their antipruritic properties are generally less prominent. Therefore, they may serve as active comparators to other investigated drugs. As an example, cetirizine failed to diminish CKD-aI in two studies, in contrast to naltrexone [319] and sodium thiosulfate [320].

\subsubsection{Gabapentinoids}

The group of gabapentinoids encompasses two drugs which possess chemical structure derived from a physiological neurotransmitter, $\gamma$-aminobutyric acid (GABA). However, gabapentin and pregabalin in fact bind to $\alpha 2 \delta$ subunit of presynaptic voltage-gated calcium channels $\left(\mathrm{Ca}_{\mathrm{v}}\right)$. This action hinders $\mathrm{Ca}^{2+}$ influx and prevents the release of excitatory neurotransmitters [321]. Gabapentinoids are mainly considered as antiepileptic drugs. Notably, they have also proven useful in the management of psychiatric disorders (such as bipolar disorder) and neuropathic pain [322,323]. Up to date, gabapentin [314,316,317,324-332] and pregabalin $[315,327,328,332-336]$ constitute the most effective systemic treatment of CKD-aI in adults, with several hundred reported patients in the literature. Direct comparison between both drugs revealed no difference between their effectiveness [327,328,332], although gabapentin may be switched to pregabalin in case of insufficient tolerance. As mentioned in Cochrane systematic review on CKD-aI, GABA analogues have been studied in the highest number of RCT and both demonstrated the greatest effect size versus their comparators [309]. Importantly, the authors also emphasized that gabapentin is rarely mentioned as the first line of therapy in different guidelines on CKD-aI, while the most common practice still involves $\mathrm{H}_{1}$-antihistamines. Although we were unable to identify any literature on gabapentinoids and their usage in paediatric CKD-aI, their clinical value has been reported in children and adolescents suffering from post-burn pruritus [337-340].

\subsubsection{Ondansetron}

Ondansetron is a competitive antagonist of serotonin $5-\mathrm{HT}_{3}$ receptor and is used as a prophylactic and therapeutic agent against nausea and vomiting associated with chemotherapy, radiotherapy and surgery [341,342]. This drug was also used off-label (although with mixed results) in the treatment of pruritus associated with cholestasis [35,343-347] and prophylaxis of opioid-induced pruritus [348-350]. Despite the promising findings reported by Balaskas et al. [183], most of the later studies were unable to confirm the benefits of ondansetron in managing CKD-aI [335,351-353]. Nevertheless, based on our literature search, a case report by Deshpande [41] is the only paper which specifically mentions therapeutic aspect of CKD-aI in a child. Therein, the author recounts a case of a 15-year-old girl with systemic symptoms of uraemia and eGFR $10 \mathrm{~mL} / \mathrm{min}$. She was also bothered by 
severe pruritus which had started 8 months earlier. After starting PD, her clinical symptoms and laboratory parameters improved. However, pruritus worsened over the course of several months, appearing throughout the day and affecting sleep. The introduction of ondansetron (16 mg daily) resulted in a dramatic improvement and pruritus subsided within 2 weeks. Following withdrawal of ondansetron, pruritus promptly reappeared, with a subsequent disappearance due to reintroduction of the drug $(8 \mathrm{mg} / \mathrm{d})$. This case illustrates beneficial outcome of ondansetron in terms of CDK-aI resolution in a child, yet further studies on a larger group of young patients with this symptom are necessary to reach more definite conclusions.

\subsection{Modalities Targeting PBUT \\ 4.4.1. Reducing Production}

Reduced production of PBUT may be achieved by targeting early phases of the process. Several studies revealed that particular dietary interventions can decrease PBUT generation, including IS and pCS. The available literature supports the introduction of vegetarian diet [354], very low protein diet [355,356], Mediterranean diet [356] and higher intake of fibre [56,357-359]. However, protein restriction is not recommended in children with CKD as it has not been shown to influence the decrease in kidney function in children and may impair growth [360]. The findings by Rossi et al. [358] support the use of protein/fibre ratio due to better correlation with serum concentrations of both IS and pCS. Notably, El-Amouri et al. [56] documented an association between increased consumption of fibre and lower serum concentrations of free IS and free pCS in children with CKD. Other studies in humans demonstrated favourable effects on serum PBUT with the usage of probiotics [361,362], prebiotics [363-365] and synbiotics (probiotics and prebiotics used concurrently) [366-370]. In short, probiotics contain living species of certain beneficial bacterial strains which alter intestinal microbiota and decrease inflammatory state, whereas prebiotics are non-digestible substances present in food, stimulating growth and activity of certain bacteria in colon [115]. The introduction of both modalities may therefore result in lower production of UTs, especially PBUT. Nevertheless, some publications revealed no effect of probiotics on the generation of PBUT [371], including a Korean study conducted in children on HD [372].

In order to minimize the production of PBUT, other concept was introduced into practice as well. Essentially, constipation is a frequent symptom associated with CKD, affecting between $14.2-71.7 \%$ of dialysis patients [373]. As reported in the literature, accumulation of certain PBUT (especially pCS) may predispose to decreased bowel movements $[374,375]$. It is possible that pCS exerts proinflammatory effects which compromise bowel movements. On the other hand, if a constipation already occurs in a CKD patient, this could also predispose to a shift in bacterial metabolism, favouring proteolytic over saccharolytic activity [373]. Consequently, bacteria would be more prone to generate additional amounts of UTs and further perpetuate the process. These bilateral associations between impaired bowel mobility and the generation of UTs may have some practical implications, e.g., increasing dietary fibre intake to enhance bowel movements or to use laxatives. We underscore that there is no data which links such interventions in patients with CKD to the actual outcome of CKD-aI alleviation or disappearance, let alone in the paediatric population.

\subsubsection{Reducing Absorption}

The overproduction of gut-derived UTs seems inevitable in advanced stages of CKD. Still, among many harmful substances, bacteria essentially produce the precursors of IS and $\mathrm{pCS}$. This provides physicians with an opportunity to bind indole and $p$-cresole in the gut to minimize their absorption into the bloodstream, e.g., with activated charcoal. In fact, two studies have proven its effectiveness in managing adults with CKD-aI [376,377] ( $n=34$ in total), although none assessed if serum concentrations of IS, pCS or other UTs were initially elevated or concurrently diminished along with the alleviation of pruritus. Regardless, we deem these finding interesting due to several reasons. Firstly, activated 
charcoal is a safe treatment method with no serious adverse effects, although frequently associated with gastrointestinal symptoms. Interestingly, both studies on CKD-aI reported good tolerance [376,377]. As pointed out by Fusaro [378], it is also important to consider the use of other concomitant drugs as their absorption may be affected. Secondly, activated charcoal can be used even in small children if needed. Lastly, compared to many other drugs (including topical dermatologic preparations), it is relatively cheap, enhancing its availability to the patients in difficult economic situation. It seems that further studies on activated charcoal in the treatment of CKD-aI are required, with the particular emphasis on children.

AST-120 is an oral spherical carbon adsorbent, insoluble in water, and characterized by porous carbon particles [379]. Up to date, this compound has been approved in several Asian countries in the treatment of CKD. Although two major RCT demonstrated no definitive benefits in terms of diminishing CKD progression or mortality [380,381], a 1991 report by Niwa et al. [382] revealed a statistically significant decrease of serum IS concentration when compared to placebo after introducing AST-120 in a small group of CKD patients on HD $(n=26)$. This cohort also included ten patients initially suffering from generalized CKD-aI. In total, nine patients experienced any decrease in pruritus intensity, with five of them-completely. Although pruritic subjects did not differ from healthy controls in terms of baseline serum IS concentrations, the therapy with AST-120 led to a significant decrease of IS concentration $(p<0.05)$. We found no other studies linking AST-120 to the treatment of CKD-aI in adults nor any data on its use in children with CKD.

\subsubsection{Increasing Clearance}

As mentioned in previous paragraphs, there is some evidence linking MM and PBUT accumulation to CKD-aI. Setting aside their actual causative and quantitative influence on CKD-aI, these UTs are difficult to be cleared, regardless of the dialysis modality chosen by the physician. Studies published up to date consistently reported that PBUT constitute the most difficult fraction to be cleared, even with the use of convective methods [383-386]. Moreover, according to Krieter et al. [387], instantaneous removal of IS and pCS via lowflux HD, HFHD or HDF cannot prevent their reappearance in a longer term. Brettschneider et al. [388] used fractionated plasma separation and adsorption (FPAD), with marked reduction ratio (RR) for both IS and pCS. According to a recent systematic review, this technique provided the highest RR concerning IS and pCS (78.2\% and $71 \%$, respectively) among the in vivo studies published up to date [389]. A combination approach to the removal of PBUT may also be beneficial, such as employing divinylbenzenic resin HD together with the intake of synbiotic [390]. Clearly, the removal of PBUT is a continuously evolving topic, with new concepts, materials, devices and techniques reported in recent years. The notable examples include mixed matrix membranes [391], direct hemoperfusion with activated carbon [392], liposome-supported HD [393] or ibuprofen infusion during HD [394], to mention just a few. Although the data in paediatric population is scarce, a recent study has evaluated the outcomes of post-dilution HDF, low-flux HD and HFHD in terms of PBUT clearance in children. Unfortunately, no differences have been observed in PBUT clearance after 12 months, regardless of the chosen modality [53]. It must be noted that post-dilution HDF did in fact result in more successful clearance of $\beta_{2}-\mathrm{M}(p<0.01)$, which is a MM already reviewed in previous paragraphs. In conclusion, it seems that RKF is still a crucial parameter, even in ESRD patients, which provides significant (although not complete) clearance of PBUT from the organism [52,395-397]. Ultimately, if this mechanism fails as well, RTx remains the only option capable of introducing better control of PBUT concentrations [398,399] and preventing, at least partially, the plethora of possible associated complications. Following RTx, still no guarantee can be made on the disappearance of CKD-aI. Nevertheless, it bothers significantly lower fraction of adult patients than previously [26-28]. Based on our personal experience, children initially suffering from CKD-aI also benefit from RTx, with the majority of young recipients finally free from this symptom (unpublished data). 


\section{Conclusions}

CKD-aI is an important symptom in adult CKD population, with significant epidemiology, clinical characteristics and outcomes. Its pathogenesis is particularly complex, although certain main domains are now clearly established. These include metabolic disequilibrium, immune dysfunction, altered opioid transmission, coexistence of infections, xerosis, neuropathy and various dialysis-associated factors. The "classic" dermatological approach to CKD-aI management is based on topical therapy, phototherapy and systemic therapy. These modalities are mainly represented by emollients, NB-UVB and psychoactive drugs (especially gabapentinoids), respectively. In short, these methods aim to improve xerosis and replenish skin barrier, reduce inflammation and interfere with the conduction and processing of neural impulses during itch pathway. Moreover, as the data on the role of UTs (and PBUT in particular) in various aspects of CKD is rapidly growing, we are also witnessing new concepts linking UTs to the development of CKD-aI. It seems evident that targeting UTs, although still problematic, will play an increasing role in the comprehensive approach to numerous systemic complications of CKD, including CKD-aI.

Concurrently, based on the scarce available data, CKD-aI in children occurs less commonly and with a more benign course than in adults. Certain differences in the epidemiology of underlying disorders contributing to CKD are evident when comparing individuals from different age groups. Consequently, it is also unknown to what extent the pathogenesis of paediatric CKD-aI differs from the adult population. Provided that the data on the role of UTs (and PBUT in particular) in eliciting CKD-aI is still insufficient among adults, the extrapolation of such associations to children should be even more cautious. We recommend that the basic therapeutic approach to a child with CKD-aI should rely mainly on the meticulous surveillance and therapy by an experienced paediatric nephrologist, supported by the general antipruritic recommendations and the application of emollients. Should these modalities fail to diminish pruritus, the instigation of phototherapy or systemic medications may be considered in rare cases, following dermatological consultation.

Author Contributions: Conceptualization: R.R., K.K.-P. and J.C.S.; methodology: R.R., K.K.-P. and J.C.S.; formal analysis: R.R., K.K.-P. and J.C.S.; investigation: R.R., K.K.-P. and J.C.S.; writingoriginal draft preparation: R.R., K.K.-P. and J.C.S.; writing-review and editing, R.R., K.K.-P. and J.C.S.; visualization: R.R.; supervision: R.R., K.K.-P. and J.C.S. All authors have read and agreed to the published version of the manuscript.

Funding: The study received no funding.

Institutional Review Board Statement: Not applicable.

Informed Consent Statement: Not applicable.

Data Availability Statement: Not applicable.

Conflicts of Interest: The authors declare no conflict of interest.

\section{References}

1. Weisshaar, E.; Szepietowski, J.C.; Dalgard, F.J.; Garcovich, S.; Gieler, U.; Giménez-Arnau, A.M.; Lambert, J.; Leslie, T.; Mettang, T.; Misery, L.; et al. European S2k Guideline on Chronic Pruritus. Acta Derm. Venereol. 2019, 99, 469-506. [CrossRef]

2. Ständer, S.; Weisshaar, E.; Mettang, T.; Szepietowski, J.C.; Carstens, E.; Ikoma, A.; Bergasa, N.V.; Gieler, U.; Misery, L.; Wallengren, J.; et al. Clinical classification of itch: A position paper of the International Forum for the Study of Itch. Acta Derm. Venereol. 2007, 87, 291-294. [CrossRef]

3. Levey, A.S.; Eckardt, K.U.; Tsukamoto, Y.; Levin, A.; Coresh, J.; Rossert, J.; De Zeeuw, D.; Hostetter, T.H.; Lameire, N.; Eknoyan, G. Definition and classification of chronic kidney disease: A position statement from Kidney Disease: Improving Global Outcomes (KDIGO). Kidney Int. 2005, 67, 2089-2100. [CrossRef]

4. Hill, N.R.; Fatoba, S.T.; Oke, J.L.; Hirst, J.A.; O'Callaghan, C.A.; Lasserson, D.S.; Hobbs, F.D. Global Prevalence of Chronic Kidney Disease-A Systematic Review and Meta-Analysis. PLoS ONE 2016, 11, e0158765. [CrossRef]

5. GBD Chronic Kidney Disease Collaboration. Global, regional, and national burden of chronic kidney disease, 1990-2017: A systematic analysis for the Global Burden of Disease Study 2017. Lancet 2020, 395, 709-733. [CrossRef]

6. Mishra, O.P.; Rai, A.K.; Srivastava, P.; Pandey, K.; Abhinay, A.; Prasad, R.; Mishra, R.N.; Schaefer, F. Predictive ability of urinary biomarkers for outcome in children with acute kidney injury. Pediatr. Nephrol. 2017, 32, 521-527. [CrossRef] 
7. Harambat, J.; van Stralen, K.J.; Kim, J.J.; Tizard, E.J. Epidemiology of chronic kidney disease in children. Pediatr. Nephrol. 2012, 27, 363-373. [CrossRef]

8. Kaspar, C.D.; Bholah, R.; Bunchman, T.E. A Review of Pediatric Chronic Kidney Disease. Blood Purif. 2016, 41, 211-217. [CrossRef]

9. National Institute of Diabetes and Digestive and Kidney Diseases. Chronic Kidney Disease in Children Study: CKiD. Available online: https://www.niddk.nih.gov/about-niddk/research-areas/kidney-disease/chronic-kidney-disease-children-study-ckid (accessed on 30 April 2021).

10. McDonald, S.P.; Craig, J.C.; Australian and New Zealand Paediatric Nephrology Association. Long-term survival of children with end-stage renal disease. N. Engl. J. Med. 2004, 350, 2654-2662. [CrossRef]

11. Gerson, A.C.; Wentz, A.; Abraham, A.G.; Mendley, S.R.; Hooper, S.R.; Butler, R.W.; Gipson, D.S.; Lande, M.B.; Shinnar, S.; Moxey-Mims, M.M.; et al. Health-related quality of life of children with mild to moderate chronic kidney disease. Pediatrics 2010, 125, e349-e357. [CrossRef]

12. Marciano, R.C.; Soares, C.M.; Diniz, J.S.; Lima, E.M.; Silva, J.M.; Canhestro, M.R.; Gazzinelli, A.; Melo, C.C.; Dias, C.S.; Simões e Silva, A.C.; et al. Behavioral disorders and low quality of life in children and adolescents with chronic kidney disease. Pediatr. Nephrol. 2011, 26, 281-290. [CrossRef] [PubMed]

13. Kiliś-Pstrusińska, K.; Medyńska, A.; Chmielewska, I.B.; Grenda, R.; Kluska-Jóźwiak, A.; Leszczyńska, B.; Niedomagała, J.; Olszak-Szot, I.; Miklaszewska, M.; Szczepańska, M.; et al. Perception of health-related quality of life in children with chronic kidney disease by the patients and their caregivers: Multicentre national study results. Qual. Life Res. 2013, 22, $2889-2897$. [CrossRef] [PubMed]

14. Ständer, S.; Schäfer, I.; Phan, N.Q.; Blome, C.; Herberger, K.; Heigel, H.; Augustin, M. Prevalence of chronic pruritus in Germany: Results of a cross-sectional study in a sample working population of 11,730. Dermatology 2010, 221, 229-235. [CrossRef] [PubMed]

15. Matterne, U.; Apfelbacher, C.J.; Vogelgsang, L.; Loerbroks, A.; Weisshaar, E. Incidence and Determinants of Chronic Pruritus: A Population-based Cohort Study. Acta Derm. Venereol. 2013, 93, 532-537. [CrossRef]

16. Amatya, B.; Wennersten, G.; Nordlind, K. Patients' perspective of pruritus in chronic plaque psoriasis: A questionnaire-based study. J. Eur. Acad. Dermatol. Venereol. 2008, 22, 822-826. [CrossRef]

17. Kaaz, K.; Szepietowski, J.C.; Matusiak, Ł. Influence of Itch and Pain on Sleep Quality in Atopic Dermatitis and Psoriasis. Acta Derm. Venereol. 2019, 99, 175-180. [CrossRef]

18. Dalgard, F.J.; Svensson, Å.; Halvorsen, J.A.; Gieler, U.; Schut, C.; Tomas-Aragones, L.; Lien, L.; Poot, F.; Jemec, G.B.E.; Misery, L.; et al. Itch and Mental Health in Dermatological Patients across Europe: A Cross-Sectional Study in 13 Countries. J. Investig. Dermatol. 2020, 140, 568-573. [CrossRef]

19. Dimitrov, D.; Matusiak, Ł.; Szepietowski, J.C. Stigmatization in Arabic psoriatic patients in the United Arab Emirates-A cross sectional study. Postepy Dermatol. Alergol. 2019, 36, 425-430. [CrossRef]

20. Sampogna, F.; Abeni, D.; Gieler, U.; Tomas-Aragones, L.; Lien, L.; Titeca, G.; Jemec, G.B.; Misery, L.; Szabó, C.; Linder, M.D.; et al. Impairment of Sexual Life in 3485 Dermatological Outpatients From a Multicentre Study in 13 European Countries. Acta Derm. Venereol. 2017, 97, 478-482. [CrossRef]

21. Hawro, T.; Przybyłowicz, K.; Spindler, M.; Hawro, M.; Steć, M.; Altrichter, S.; Weller, K.; Magerl, M.; Reidel, U.; Alarbeed, E.; et al. The characteristics and impact of pruritus in adult dermatologic patients: A prospective, cross-sectional study. J. Am. Acad. Dermatol. 2021, 84, 691-700. [CrossRef]

22. Pisoni, R.L.; Wikström, B.; Elder, S.J.; Akizawa, T.; Asano, Y.; Keen, M.L.; Saran, R.; Mendelssohn, D.C.; Young, E.W.; Port, F.K. Pruritus in haemodialysis patients: International results from the Dialysis Outcomes and Practice Patterns Study (DOPPS). Nephrol. Dial. Transplant. 2006, 21, 3495-3505. [CrossRef]

23. Sukul, N.; Speyer, E.; Tu, C.; Bieber, B.A.; Li, Y.; Lopes, A.A.; Asahi, K.; Mariani, L.; Laville, M.; Rayner, H.C.; et al. Pruritus and Patient Reported Outcomes in Non-Dialysis CKD. Clin. J. Am. Soc. Nephrol. 2019, 14, 673-681. [CrossRef]

24. Li, J.; Guo, Q.; Lin, J.; Yi, C.; Yang, X.; Yu, X. Prevalence and Associated Factors of Uraemic Pruritus in Continuous Ambulatory Peritoneal Dialysis Patients. Intern. Med. 2015, 54, 2827-2833. [CrossRef]

25. Min, J.W.; Kim, S.H.; Kim, Y.O.; Jin, D.C.; Song, H.C.; Choi, E.J.; Kim, Y.L.; Kim, Y.S.; Kang, S.W.; Kim, N.H.; et al. Comparison of uremic pruritus between patients undergoing hemodialysis and peritoneal dialysis. Kidney Res. Clin. Pract. 2016, 35, 107-113. [CrossRef] [PubMed]

26. Panuccio, V.; Tripepi, R.; Bellantoni, M.; Saporito, L.; Quattrone, S.; Lacava, V.; Parlongo, G.; Tripepi, G.; Mallamaci, F.; Zoccali, C. Pruritus and quality of life in renal transplant patients. Clin. Transplant. 2017, 31. [CrossRef] [PubMed]

27. Schricker, S.; Weisshaar, E.; Kupfer, J.; Mettang, T. Prevalence of Pruritus in a Single Cohort of Long-term Kidney Transplant Recipients. Acta Derm. Venereol. 2020, 100, adv00066. [CrossRef]

28. Krajewski, P.K.; Olczyk, P.; Krajewska, M.; Krajewski, W.; Szepietowski, J.C. Clinical Characteristics of Itch in Renal Transplant Recipients. Front. Med. 2021, 7, 615334. [CrossRef]

29. Murphy, E.L.; Murtagh, F.E.; Carey, I.; Sheerin, N.S. Understanding symptoms in patients with advanced chronic kidney disease managed without dialysis: use of a short patient-completed assessment tool. Nephron Clin. Pract. 2009, 111, c74-c80. [CrossRef]

30. Solak, B.; Acikgoz, S.B.; Sipahi, S.; Erdem, T. Epidemiology and determinants of pruritus in pre-dialysis chronic kidney disease patients. Int. Urol. Nephrol. 2016, 48, 585-591. [CrossRef]

31. David, T.J.; Wybrew, M.; Hennessen, U. Prodromal itching in childhood asthma. Lancet 1984, 2, 154-155. [CrossRef] 
32. Yerushalmi, B.; Sokol, R.J.; Narkewicz, M.R.; Smith, D.; Karrer, F.M. Use of rifampin for severe pruritus in children with chronic cholestasis. J. Pediatr. Gastroenterol. Nutr. 1999, 29, 442-447. [CrossRef]

33. El-Karaksy, H.; Mansour, S.; El-Sayed, R.; El-Raziky, M.; El-Koofy, N.; Taha, G. Safety and efficacy of rifampicin in children with cholestatic pruritus. Indian J. Pediatr. 2007, 74, 279-281. [CrossRef]

34. Ramachandran, P.; Shanmugam, N.P.; Sinani, S.A.; Shanmugam, V.; Srinivas, S.; Sathiyasekaran, M.; Tamilvanan, V.; Rela, M. Outcome of partial internal biliary diversion for intractable pruritus in children with cholestatic liver disease. Pediatr. Surg. Int. 2014, 30, 1045-1049. [CrossRef]

35. Thébaut, A.; Habes, D.; Gottrand, F.; Rivet, C.; Cohen, J.; Debray, D.; Jacquemin, E.; Gonzales, E. Sertraline as an Additional Treatment for Cholestatic Pruritus in Children. J. Pediatr. Gastroenterol. Nutr. 2017, 64, 431-435. [CrossRef] [PubMed]

36. Van Vaisberg, V.; Tannuri, A.C.A.; Lima, F.R.; Tannuri, U. Ileal exclusion for pruritus treatment in children with progressive familial intrahepatic cholestasis and other cholestatic diseases. J. Pediatr. Surg. 2020, 55, 1385-1391. [CrossRef] [PubMed]

37. Belzberg, M.; Larson, V.A.; Khanna, R.; Williams, K.A.; Semenov, Y.; Ständer, S.; Grossberg, A.L.; Kwatra, S.G. Association between Itch and Cancer in 3836 Pediatric Pruritus Patients at a Tertiary Care Center. Medicines 2019, 6, 99. [CrossRef]

38. Stefaniak, A.A.; Zubkiewicz-Kucharska, A.; Matusiak, Ł.; Noczyńska, A.; Szepietowski, J.C. Itch in Children with Type 1 Diabetes: A Cross-Sectional Study. Dermatol. Ther. 2020, 10, 745-756. [CrossRef]

39. Silverberg, N.B.; Singh, A.; Laude, T.A. Cutaneous manifestations of chronic renal failure in children of color. Pediatr. Dermatol. 2001, 18, 199-204. [CrossRef]

40. Mettang, T.; Pauli-Magnus, C.; Alscher, D.M. Uraemic pruritus-New perspectives and insights from recent trials. Nephrol. Dial. Transplant. 2002, 17, 1558-1563. [CrossRef]

41. Deshpande, P.V. Ondansetron for paediatric uraemic pruritus, a case report. Pediatr. Nephrol. 2004, 19, 694-696. [CrossRef]

42. Senturk, N.; Ozkaya, O.; Aytekin, S.; Bek, K.; Açikgöz, Y.; Aydin, F.; Bek, Y.; Turanli, A.Y. Characteristics of pruritus in children on peritoneal dialysis. Nephron Clin. Pract. 2008, 109, c168-c172. [CrossRef]

43. Attia, E.A.; Hassan, S.I.; Youssef, N.M. Cutaneous disorders in uremic patients on hemodialysis: An Egyptian case-controlled study. Int. J. Dermatol. 2010, 49, 1024-1030. [CrossRef] [PubMed]

44. Wojtowicz-Prus, E.; Kiliś-Pstrusińska, K.; Reich, A.; Zachwieja, K.; Miklaszewska, M.; Szczepanska, M.; Szepietowski, J.C. Chronic Kidney Disease-associated Pruritus in Children. Acta Derm. Venereol. 2016, 96, 938-942. [CrossRef]

45. The European Uremic Toxins (EUTox) Database. Available online: https://database.uremic-toxins.org/home.php (accessed on 30 April 2021).

46. Meyer, T.W.; Hostetter, T.H. Uremia. N. Engl. J. Med. 2007, 357, 1316-1325. [CrossRef]

47. Duranton, F.; Cohen, G.; De Smet, R.; Rodriguez, M.; Jankowski, J.; Vanholder, R.; Argiles, A.; European Uremic Toxin Work Group. Normal and pathologic concentrations of uremic toxins. J. Am. Soc. Nephrol. 2012, 23, 1258-1270. [CrossRef] [PubMed]

48. Clark, W.R.; Dehghani, N.L.; Narsimhan, V.; Ronco, C. Uremic Toxins and their Relation to Dialysis Efficacy. Blood Purif. 2019, 48, 299-314. [CrossRef] [PubMed]

49. Snauwaert, E.; Van Biesen, W.; Raes, A.; Glorieux, G.; Vanholder, R.; Vande Walle, J.; Eloot, S. A plea for more uremic toxin research in children with chronic kidney disease. Pediatr. Nephrol. 2018, 33, 921-924. [CrossRef] [PubMed]

50. Snauwaert, E.; Van Biesen, W.; Raes, A.; Glorieux, G.; Van Bogaert, V.; Van Hoeck, K.; Coppens, M.; Roels, S.; Vande Walle, J.; Eloot, S. Concentrations of representative uraemic toxins in a healthy versus non-dialysis chronic kidney disease paediatric population. Nephrol. Dial. Transplant. 2018, 33, 978-986. [CrossRef]

51. Snauwaert, E.; Van Biesen, W.; Raes, A.; Holvoet, E.; Glorieux, G.; Van Hoeck, K.; Van Dyck, M.; Godefroid, N.; Vanholder, R.; Roels, S.; et al. Accumulation of uraemic toxins is reflected only partially by estimated GFR in paediatric patients with chronic kidney disease. Pediatr. Nephrol. 2018, 33, 315-323. [CrossRef]

52. Snauwaert, E.; Holvoet, E.; Van Biesen, W.; Raes, A.; Glorieux, G.; Vande Walle, J.; Roels, S.; Vanholder, R.; Askiti, V.; Azukaitis, K.; et al. Uremic Toxin Concentrations are Related to Residual Kidney Function in the Pediatric Hemodialysis Population. Toxins 2019, 11, 235. [CrossRef]

53. Snauwaert, E.; Van Biesen, W.; Raes, A.; Glorieux, G.; Vande Walle, J.; Roels, S.; Vanholder, R.; Askiti, V.; Azukaitis, K.; Bayazit, A.; et al. Haemodiafiltration does not lower protein-bound uraemic toxin levels compared with haemodialysis in a paediatric population. Nephrol. Dial. Transplant. 2020, 35, 648-656. [CrossRef] [PubMed]

54. Holle, J.; Querfeld, U.; Kirchner, M.; Anninos, A.; Okun, J.; Thurn-Valsassina, D.; Bayazit, A.; Niemirska, A.; Canpolat, N.; Bulut, I.K.; et al. Indoxyl sulfate associates with cardiovascular phenotype in children with chronic kidney disease. Pediatr. Nephrol. 2019, 34, 2571-2582. [CrossRef] [PubMed]

55. Holle, J.; Kirchner, M.; Okun, J.; Bayazit, A.K.; Obrycki, L.; Canpolat, N.; Bulut, I.K.; Azukaitis, K.; Duzova, A.; Ranchin, B.; et al. Serum indoxyl sulfate concentrations associate with progression of chronic kidney disease in children. PLoS ONE 2020, 15, e0240446. [CrossRef]

56. El Amouri, A.; Snauwaert, E.; Foulon, A.; Vande Moortel, C.; Van Dyck, M.; Van Hoeck, K.; Godefroid, N.; Glorieux, G.; Van Biesen, W.; Vande Walle, J.; et al. Dietary Fibre Intake Is Associated with Serum Levels of Uraemic Toxins in Children with Chronic Kidney Disease. Toxins 2021, 13, 225. [CrossRef]

57. Vanholder, R.; De Smet, R.; Glorieux, G.; Argilés, A.; Baurmeister, U.; Brunet, P.; Clark, W.; Cohen, G.; De Deyn, P.P.; Deppisch, R.; et al. Review on uremic toxins: classification, concentration, and interindividual variability. Kidney Int. 2003, 63, 1934-1943. [CrossRef] 
58. Bellomo, G. Uric acid and chronic kidney disease: A time to act? World J. Nephrol. 2013, 2, 17-25. [CrossRef]

59. Oh, T.R.; Choi, H.S.; Kim, C.S.; Bae, E.H.; Ma, S.K.; Sung, S.A.; Kim, Y.S.; Oh, K.H.; Ahn, C.; Kim, S.W. Hyperuricemia has increased the risk of progression of chronic kidney disease: Propensity score matching analysis from the KNOW-CKD study. Sci. Rep. 2019, 9, 6681. [CrossRef]

60. Srivastava, A.; Kaze, A.D.; McMullan, C.J.; Isakova, T.; Waikar, S.S. Uric Acid and the Risks of Kidney Failure and Death in Individuals With CKD. Am. J. Kidney Dis. 2018, 71, 362-370. [CrossRef]

61. Rodenbach, K.E.; Schneider, M.F.; Furth, S.L.; Moxey-Mims, M.M.; Mitsnefes, M.M.; Weaver, D.J.; Warady, B.A.; Schwartz, G.J. Hyperuricemia and Progression of CKD in Children and Adolescents: The Chronic Kidney Disease in Children (CKiD) Cohort Study. Am. J. Kidney Dis. 2015, 66, 984-992. [CrossRef]

62. Wang, C.P.; Lu, Y.C.; Tsai, I.T.; Tang, W.H.; Hsu, C.C.; Hung, W.C.; Yu, T.H.; Chen, S.C.; Chung, F.M.; Lee, Y.J.; et al. Increased Levels of Total p-Cresylsulfate Are Associated with Pruritus in Patients with Chronic Kidney Disease. Dermatology 2016, 232, 363-370. [CrossRef]

63. Noh, S.H.; Park, K.; Kim, E.J. The Incidence of Pruritus and Biochemical Marker Associated with Pruritus in Hemodialysis Patients. Ann. Dermatol. 2018, 30, 473-475. [CrossRef] [PubMed]

64. Chmielewski, M.; Cohen, G.; Wiecek, A.; Jesús Carrero, J. The peptidic middle molecules: Is molecular weight doing the trick? Semin. Nephrol. 2014, 34, 118-134. [CrossRef]

65. Zügel, U.; Schoel, B.; Kaufmann, S.H. Beta 2-microglobulin independent presentation of exogenously added foreign peptide and endogenous self-epitope by MHC class I alpha-chain to a cross-reactive CD8+ CTL clone. J. Immunol. 1994, 153, 4070-4080.

66. Drüeke, T.B.; Massy, Z.A. Beta2-microglobulin. Semin. Dial. 2009, 22, 378-380. [CrossRef]

67. Gejyo, F.; Odani, S.; Yamada, T.; Honma, N.; Saito, H.; Suzuki, Y.; Nakagawa, Y.; Kobayashi, H.; Maruyama, Y.; Hirasawa, Y.; et al. Beta 2-microglobulin: A new form of amyloid protein associated with chronic hemodialysis. Kidney Int. 1986, 30, 385-390. [CrossRef]

68. Wu, H.C.; Lee, L.C.; Wang, W.J. Associations among Serum Beta 2 Microglobulin, Malnutrition, Inflammation, and Advanced Cardiovascular Event in Patients with Chronic Kidney Disease. J. Clin. Lab. Anal. 2017, 31, e22056. [CrossRef]

69. Liabeuf, S.; Lenglet, A.; Desjardins, L.; Neirynck, N.; Glorieux, G.; Lemke, H.D.; Vanholder, R.; Diouf, M.; Choukroun, G.; Massy, Z.A.; et al. Plasma beta-2 microglobulin is associated with cardiovascular disease in uremic patients. Kidney Int. 2012, 82, 1297-1303. [CrossRef]

70. Cheung, A.K.; Greene, T.; Leypoldt, J.K.; Yan, G.; Allon, M.; Delmez, J.; Levey, A.S.; Levin, N.W.; Rocco, M.V.; Schulman, G.; et al. Association between Serum $\beta 2$-Microglobulin Level and Infectious Mortality in Hemodialysis Patients. Clin. J. Am. Soc. Nephrol. 2008, 3, 69-77. [CrossRef]

71. Okuno, S.; Ishimura, E.; Kohno, K.; Fujino-Katoh, Y.; Maeno, Y.; Yamakawa, T.; Inaba, M.; Nishizawa, Y. Serum $\beta 2$-microglobulin level is a significant predictor of mortality in maintenance haemodialysis patients. Nephrol. Dial. Transplant. 2009, 24, 571-577. [CrossRef]

72. Foster, M.C.; Coresh, J.; Hsu, C.Y.; Xie, D.; Levey, A.S.; Nelson, R.G.; Eckfeldt, J.H.; Vasan, R.S.; Kimmel, P.L.; Schelling, J.; et al. Serum $\beta$-Trace Protein and $\beta 2$-Microglobulin as Predictors of ESRD, Mortality, and Cardiovascular Disease in Adults With CKD in the Chronic Renal Insufficiency Cohort (CRIC) Study. Am. J. Kidney. Dis. 2016, 68, 68-76. [CrossRef]

73. Argyropoulos, C.P.; Chen, S.S.; Ng, Y.H.; Roumelioti, M.E.; Shaffi, K.; Singh, P.P.; Tzamaloukas, A.H. Rediscovering Beta-2 Microglobulin As a Biomarker across the Spectrum of Kidney Diseases. Front. Med. 2017, 4, 73. [CrossRef]

74. Narita, I.; Alchi, B.; Omori, K.; Sato, F.; Ajiro, J.; Saga, D.; Kondo, D.; Skatsume, M.; Maruyama, S.; Kazama, J.J.; et al. Etiology and prognostic significance of severe uremic pruritus in chronic hemodialysis patients. Kidney Int. 2006, 69, 1626-1632. [CrossRef] [PubMed]

75. Chen, Z.J.; Cao, G.; Tang, W.X.; Lv, X.Y.; Huang, S.M.; Qin, W.; Ping, F.; Ye, T. A randomized controlled trial of high-permeability haemodialysis against conventional haemodialysis in the treatment of uraemic pruritus. Clin. Exp. Dermatol. 2009, 34, 679-683. [CrossRef] [PubMed]

76. Melo, N.C.; Elias, R.M.; Castro, M.C.; Romao, J.E., Jr.; Abensur, H. Pruritus in hemodialysis patients: The problem remains. Hemodial. Int. 2009, 13, 38-42. [CrossRef] [PubMed]

77. Assounga, A.G.; Bascoul, S.; Canaud, B.; Bouya, P.A.; Vendrell, J.P.; Sciolla, J.P.; Mourad, G.; Baldet, P.; Serre, A.; Mion, C. A study of beta 2-microglobulin skin deposits in dialyzed patients and healthy controls. Am. J. Kidney Dis. 1990, 15, 556-561. [CrossRef]

78. Andoh, T.; Maki, T.; Li, S.; Uta, D. $\beta 2$-Microglobulin elicits itch-related responses in mice through the direct activation of primary afferent neurons expressing transient receptor potential vanilloid 1. Eur. J. Pharmacol. 2017, 810, 134-140. [CrossRef]

79. Goltzman, D. Physiology of Parathyroid Hormone. Front. Horm. Res. 2018, 50, 1-13. [CrossRef]

80. Tageldin, N.; Martin, A. Thyroid, parathyroid hormones and calcium homeostasis. Physiology 2020, 21, 599-603. [CrossRef]

81. Rodríguez-Ortiz, M.E.; Rodríguez, M. Recent advances in understanding and managing secondary hyperparathyroidism in chronic kidney disease. F1000Research 2020, 9, F1000. [CrossRef]

82. Wesseling-Perry, K. Bone disease in pediatric chronic kidney disease. Pediatr. Nephrol. 2013, 28, 569-576. [CrossRef]

83. Massry, S.G.; Popovtzer, M.M.; Coburn, J.W.; Makoff, D.L.; Maxwell, M.H.; Kleeman, C.R. Intractable pruritus as a manifestation of secondary hyperparathyroidism in uremia. Disappearance of itching after subtotal parathyroidectomy. N. Engl. J. Med. 1968, 279, 697-700. [CrossRef] 
84. Chou, F.F.; Ho, J.C.; Huang, S.C.; Sheen-Chen, S.M. A study on pruritus after parathyroidectomy for secondary hyperparathyroidism. J. Am. Coll. Surg. 2000, 190, 65-70. [CrossRef]

85. Makhlough, A.; Emadi, N.; Sedighi, O.; Khademloo, M.; Bicmohamadi, A.R. Relationship between serum intact parathyroid hormone and pruritus in hemodialysis patients. Iran. J. Kidney Dis. 2013, 7, 42-46.

86. Śnit, M.; Gawlik, R.; Łącka-Gaździk, B.; Kuźniewicz, R.; Dwornicki, M.; Owczarek, A.; Walaszczyk, M.; Grabiec, P.; Grzeszczak, W. Substance P and intensity of pruritus in hemodialysis and peritoneal dialysis patients. Med. Sci. Monit. 2013, 19, 723-732. [CrossRef]

87. Cho, Y.L.; Liu, H.N.; Huang, T.P.; Tarng, D.C. Uremic pruritus: Roles of parathyroid hormone and substance P. J. Am. Acad. Dermatol. 1997, 36, 538-543. [CrossRef]

88. Akhyani, M.; Ganji, M.R.; Samadi, N.; Khamesan, B.; Daneshpazhooh, M. Pruritus in hemodialysis patients. BMC Dermatol. 2005, 5, 7. [CrossRef]

89. Duque, M.I.; Thevarajah, S.; Chan, Y.H.; Tuttle, A.B.; Freedman, B.I.; Yosipovitch, G. Uremic pruritus is associated with higher kt/V and serum calcium concentration. Clin. Nephrol. 2006, 66, 184-191. [CrossRef]

90. Ståhle-Bäckdahl, M.; Hägermark, O.; Lins, L.E.; Törring, O.; Hilliges, M.; Johansson, O. Experimental and immunohistochemical studies on the possible role of parathyroid hormone in uraemic pruritus. J. Intern. Med. 1989, 225, 411-415. [CrossRef]

91. Momose, A.; Kudo, S.; Sato, M.; Saito, H.; Nagai, K.; Katabira, Y.; Funyu, T. Calcium ions are abnormally distributed in the skin of haemodialysis patients with uraemic pruritus. Nephrol. Dial. Transplant. 2004, 19, 2061-2066. [CrossRef]

92. Scheller, J.; Rose-John, S. Interleukin-6 and its receptor: From bench to bedside. Med. Microbiol. Immunol. 2006, 195, 173-183. [CrossRef] [PubMed]

93. Rose-John, S. Interleukin-6 Family Cytokines. Cold Spring Harb. Perspect. Biol. 2018, 10, a028415. [CrossRef] [PubMed]

94. Wolf, J.; Rose-John, S.; Garbers, C. Interleukin-6 and its receptors: A highly regulated and dynamic system. Cytokine 2014, 70, 11-20. [CrossRef] [PubMed]

95. Jones, L.L.; Vignali, D.A. Molecular interactions within the IL-6/IL-12 cytokine/receptor superfamily. Immunol. Res. 2011, 51, 5-14. [CrossRef]

96. Gupta, J.; Mitra, N.; Kanetsky, P.A.; Devaney, J.; Wing, M.R.; Reilly, M.; Shah, V.O.; Balakrishnan, V.S.; Guzman, N.J.; Girndt, M.; et al. Association between albuminuria, kidney function, and inflammatory biomarker profile in CKD in CRIC. Clin. J. Am. Soc. Nephrol. 2012, 7, 1938-1946. [CrossRef]

97. Amdur, R.L.; Feldman, H.I.; Gupta, J.; Yang, W.; Kanetsky, P.; Shlipak, M.; Rahman, M.; Lash, J.P.; Townsend, R.R.; Ojo, A.; et al. Inflammation and Progression of CKD: The CRIC Study. Clin. J. Am. Soc. Nephrol. 2016, 11, 1546-1556. [CrossRef]

98. Pecoits-Filho, R.; Bárány, P.; Lindholm, B.; Heimbürger, O.; Stenvinkel, P. Interleukin-6 is an independent predictor of mortality in patients starting dialysis treatment. Nephrol. Dial. Transplant. 2002, 17, 1684-1688. [CrossRef]

99. Sun, J.; Axelsson, J.; Machowska, A.; Heimbürger, O.; Bárány, P.; Lindholm, B.; Lindström, K.; Stenvinkel, P.; Qureshi, A.R. Biomarkers of Cardiovascular Disease and Mortality Risk in Patients with Advanced CKD. Clin. J. Am. Soc. Nephrol. 2016, 11, 1163-1172. [CrossRef]

100. Simmons, E.M.; Langone, A.; Sezer, M.T.; Vella, J.P.; Recupero, P.; Morrow, J.D.; Ikizler, T.A.; Himmelfarb, J. Effect of renal transplantation on biomarkers of inflammation and oxidative stress in end-stage renal disease patients. Transplantation 2005, 79, 914-919. [CrossRef]

101. Akchurin, O.; Patino, E.; Dalal, V.; Meza, K.; Bhatia, D.; Brovender, S.; Zhu, Y.S.; Cunningham-Rundles, S.; Perelstein, E.; Kumar, J.; et al. Interleukin-6 Contributes to the Development of Anemia in Juvenile CKD. Kidney Int. Rep. 2018, 4, 470-483. [CrossRef]

102. Sánchez Hernández, K.V.; Larrosa-Haro, A.; González Hita, M.; Martín Del Campo López, F.; Chávez Palencia, C.; Pérez Cortez, G.; Sandoval Pamplona, J.; Rivera León, É. Interleukine 6 and C-reactive protein predict growth impairment and acute malnutrition in children and adolescents with chronic kidney disease. Nutr. Hosp. 2019, 36, 1248-1253. [CrossRef]

103. Panahi, Y.; Davoudi, S.M.; Beiraghdar, F.; Amiri, M.; Saadat, A.; Marzony, E.T.; Naghizadeh, M.M.; Sahebkar, A. Serum levels of interleukins 2, 4, 6, and 10 in veterans with chronic sulfur mustard-induced pruritus: A cross-sectional study. Skinmed 2013, 11, 205-209.

104. Konda, D.; Chandrashekar, L.; Rajappa, M.; Kattimani, S.; Thappa, D.M.; Ananthanarayanan, P.H. Serotonin and interleukin-6: Association with pruritus severity, sleep quality and depression severity in Prurigo Nodularis. Asian J. Psychiatr. 2015, 17, 24-28. [CrossRef]

105. Kimmel, M.; Alscher, D.M.; Dunst, R.; Braun, N.; Machleidt, C.; Kiefer, T.; Stülten, C.; van der Kuip, H.; Pauli-Magnus, C.; Raub, U.; et al. The role of micro-inflammation in the pathogenesis of uraemic pruritus in haemodialysis patients. Nephrol. Dial. Transplant. 2006, 21, 749-755. [CrossRef]

106. Schricker, S.; Heider, T.; Schanz, M.; Dippon, J.; Alscher, M.D.; Weiss, H.; Mettang, T.; Kimmel, M. Strong Associations Between Inflammation, Pruritus and Mental Health in Dialysis Patients. Acta Derm. Venereol. 2019, 99, 524-529. [CrossRef]

107. Taraz, M.; Khatami, M.R.; Gharekhani, A.; Abdollahi, A.; Khalili, H.; Dashti-Khavidaki, S. Relationship between a pro- and anti-inflammatory cytokine imbalance and depression in haemodialysis patients. Eur. Cytokine Netw. 2012, 23, 179-186. [CrossRef]

108. Liu, Y.; Ho, R.C.; Mak, A. Interleukin (IL)-6, tumour necrosis factor alpha (TNF- $\alpha$ ) and soluble interleukin-2 receptors (sIL-2R) are elevated in patients with major depressive disorder: A meta-analysis and meta-regression. J. Affect. Disord. 2012, 139, 230-239. [CrossRef] 
109. Yamamoto, Y.; Hayashino, Y.; Yamazaki, S.; Akiba, T.; Akizawa, T.; Asano, Y.; Saito, A.; Kurokawa, K.; Miyachi, Y.; Fukuhara, S.; et al. Depressive symptoms predict the future risk of severe pruritus in haemodialysis patients: Japan Dialysis Outcomes and Practice Patterns Study. Br. J. Dermatol. 2009, 161, 384-389. [CrossRef]

110. Kogon, A.J.; Matheson, M.B.; Flynn, J.T.; Gerson, A.C.; Warady, B.A.; Furth, S.L.; Hooper, S.R.; Chronic Kidney Disease in Children (CKiD) Study Group. Depressive symptoms in children with chronic kidney disease. J. Pediatr. 2016, 168, 164-170.e1. [CrossRef]

111. Kogon, A.J.; Kim, J.Y.; Laney, N.; Radcliffe, J.; Hooper, S.R.; Furth, S.L.; Hartung, E.A. Depression and neurocognitive dysfunction in pediatric and young adult chronic kidney disease. Pediatr. Nephrol. 2019, 34, 1575-1582. [CrossRef] [PubMed]

112. Vanholder, R.; Schepers, E.; Pletinck, A.; Neirynck, N.; Glorieux, G. An update on protein-bound uremic retention solutes. J. Ren. Nutr. 2012, 22, 90-94. [CrossRef]

113. Meijers, B.K.; Evenepoel, P. The gut-kidney axis: Indoxyl sulfate, p-cresyl sulfate and CKD progression. Nephrol. Dial. Transplant. 2011, 26, 759-761. [CrossRef]

114. Sirich, T.L.; Meyerm, T.W.; Gondouin, B.; Brunet, P.; Niwa, T. Protein-bound molecules: A large family with a bad character. Semin. Nephrol. 2014, 34, 106-117. [CrossRef]

115. Rysz, J.; Franczyk, B.; Ławiński, J.; Olszewski, R.; Ciałkowska-Rysz, A.; Gluba-Brzózka, A. The Impact of CKD on Uremic Toxins and Gut Microbiota. Toxins 2021, 13, 252. [CrossRef]

116. Gryp, T.; Huys, G.R.B.; Joossens, M.; Van Biesen, W.; Glorieux, G.; Vaneechoutte, M. Isolation and Quantification of Uremic Toxin Precursor-Generating Gut Bacteria in Chronic Kidney Disease Patients. Int. J. Mol. Sci. 2020, 21, 1986. [CrossRef] [PubMed]

117. Lin, C.J.; Chen, H.H.; Pan, C.F.; Chuang, C.K.; Wang, T.J.; Sun, F.J.; Wu, C.J. p-Cresylsulfate and indoxyl sulfate level at different stages of chronic kidney disease. J. Clin. Lab. Anal. 2011, 25, 191-197. [CrossRef]

118. Leong, S.C.; Sirich, T.L. Indoxyl Sulfate-Review of Toxicity and Therapeutic Strategies. Toxins 2016, 8, 358. [CrossRef] [PubMed]

119. Lin, C.J.; Liou, T.C.; Pan, C.F.; Wu, P.C.; Sun, F.J.; Liu, H.L.; Chen, H.H.; Wu, C.J. The Role of Liver in Determining Serum Colon-Derived Uremic Solutes. PLoS ONE 2015, 10, e0134590. [CrossRef]

120. Wu, W.; Bush, K.T.; Nigam, S.K. Key Role for the Organic Anion Transporters, OAT1 and OAT3, in the in vivo Handling of Uremic Toxins and Solutes. Sci. Rep. 2017, 7, 4939. [CrossRef] [PubMed]

121. Niwa, T. Uremic toxicity of indoxyl sulfate. Nagoya J. Med. Sci. 2010, 72, 1-11.

122. Miyazaki, T.; Ise, M.; Seo, H.; Niwa, T. Indoxyl sulfate increases the gene expressions of TGF-beta 1, TIMP-1 and pro-alpha 1(I) collagen in uremic rat kidneys. Kidney Int. Suppl. 1997, 62, S15-S22.

123. Shimizu, H.; Bolati, D.; Adijiang, A.; Enomoto, A.; Nishijima, F.; Dateki, M.; Niwa, T. Senescence and dysfunction of proximal tubular cells are associated with activated p53 expression by indoxyl sulfate. Am. J. Physiol. Cell Physiol. 2010, 299, C1110-C1117. [CrossRef]

124. Li, S.; Cheng, S.; Sun, Z.; Mungun, H.K.; Gong, W.; Yu, J.; Xia, W.; Zhang, Y.; Huang, S.; Zhang, A.; et al. Indoxyl Sulfate Induces Mesangial Cell Proliferation via the Induction of COX-2. Mediat. Inflamm. 2016, 2016, 5802973. [CrossRef]

125. Motojima, M.; Hosokawa, A.; Yamato, H.; Muraki, T.; Yoshioka, T. Uremic toxins of organic anions up-regulate PAI-1 expression by induction of NF-kappaB and free radical in proximal tubular cells. Kidney Int. 2003, 63, 1671-1680. [CrossRef] [PubMed]

126. Gelasco, A.K.; Raymond, J.R. Indoxyl sulfate induces complex redox alterations in mesangial cells. Am. J. Physiol. Ren. Physiol. 2006, 290, F1551-F1558. [CrossRef] [PubMed]

127. Owada, S.; Goto, S.; Bannai, K.; Hayashi, H.; Nishijima, F.; Niwa, T. Indoxyl sulfate reduces superoxide scavenging activity in the kidneys of normal and uremic rats. Am. J. Nephrol. 2008, 28, 446-454. [CrossRef] [PubMed]

128. Tumur, Z.; Shimizu, H.; Enomoto, A.; Miyazaki, H.; Niwa, T. Indoxyl sulfate upregulates expression of ICAM-1 and MCP-1 by oxidative stress-induced NF-kappaB activation. Am. J. Nephrol. 2010, 31, 435-441. [CrossRef]

129. Yu, M.; Kim, Y.J.; Kang, D.H. Indoxyl sulfate-induced endothelial dysfunction in patients with chronic kidney disease via an induction of oxidative stress. Clin. J. Am. Soc. Nephrol. 2011, 6, 30-39. [CrossRef]

130. Adesso, S.; Popolo, A.; Bianco, G.; Sorrentino, R.; Pinto, A.; Autore, G.; Marzocco, S. The uremic toxin indoxyl sulphate enhances macrophage response to LPS. PLoS ONE 2013, 8, e76778. [CrossRef]

131. Rapa, S.F.; Prisco, F.; Popolo, A.; Iovane, V.; Autore, G.; Di Iorio, B.R.; Dal Piaz, F.; Paciello, O.; Nishijima, F.; Marzocco, S. Pro-Inflammatory Effects of Indoxyl Sulfate in Mice: Impairment of Intestinal Homeostasis and Immune Response. Int. J. Mol. Sci. 2021, 22, 1135. [CrossRef]

132. Matsuo, K.; Yamamoto, S.; Wakamatsu, T.; Takahashi, Y.; Kawamura, K.; Kaneko, Y.; Goto, S.; Kazama, J.J.; Narita, I. Increased Proinflammatory Cytokine Production and Decreased Cholesterol Efflux Due to Downregulation of ABCG1 in Macrophages Exposed to Indoxyl Sulfate. Toxins 2015, 7, 3155-3166. [CrossRef]

133. Wakamatsu, T.; Yamamoto, S.; Ito, T.; Sato, Y.; Matsuo, K.; Takahashi, Y.; Kaneko, Y.; Goto, S.; Kazama, J.J.; Gejyo, F.; et al. Indoxyl Sulfate Promotes Macrophage IL-1 $\beta$ Production by Activating Aryl Hydrocarbon Receptor/NF-K/MAPK Cascades, but the NLRP3 inflammasome Was Not Activated. Toxins 2018, 10, 124. [CrossRef]

134. Nakano, T.; Katsuki, S.; Chen, M.; Decano, J.L.; Halu, A.; Lee, L.H.; Pestana, D.V.S.; Kum, A.S.T.; Kuromoto, R.K.; Golden, W.S.; et al. Uremic Toxin Indoxyl Sulfate Promotes Proinflammatory Macrophage Activation Via the Interplay of OATP2B1 and Dll4-Notch Signaling. Circulation 2019, 139, 78-96. [CrossRef]

135. Barreto, F.C.; Barreto, D.V.; Liabeuf, S.; Meert, N.; Glorieux, G.; Temmar, M.; Choukroun, G.; Vanholder, R.; Massy, Z.A.; European Uremic Toxin Work Group (EUTox). Serum indoxyl sulfate is associated with vascular disease and mortality in chronic kidney disease patients. Clin. J. Am. Soc. Nephrol. 2009, 4, 1551-1558. [CrossRef] [PubMed] 
136. Wu, I.W.; Hsu, K.H.; Lee, C.C.; Sun, C.Y.; Hsu, H.J.; Tsai, C.J.; Tzen, C.Y.; Wang, Y.C.; Lin, C.Y.; Wu, M.S. p-Cresyl sulphate and indoxyl sulphate predict progression of chronic kidney disease. Nephrol. Dial. Transplant. 2011, 26, 938-947. [CrossRef] [PubMed]

137. Kamiński, T.W.; Pawlak, K.; Karbowska, M.; Myśliwiec, M.; Pawlak, D. Indoxyl sulfate-The uremic toxin linking hemostatic system disturbances with the prevalence of cardiovascular disease in patients with chronic kidney disease. BMC Nephrol. 2017, 18, 35. [CrossRef]

138. Fan, P.C.; Chang, J.C.; Lin, C.N.; Lee, C.C.; Chen, Y.T.; Chu, P.H.; Kou, G.; Lu, Y.A.; Yang, C.W.; Chen, Y.C. Serum indoxyl sulfate predicts adverse cardiovascular events in patients with chronic kidney disease. J. Formos. Med. Assoc. 2019, 118, $1099-1106$. [CrossRef] [PubMed]

139. Opdebeeck, B.; Maudsley, S.; Azmi, A.; De Maré, A.; De Leger, W.; Meijers, B.; Verhulst, A.; Evenepoel, P.; D’Haese, P.C.; Neven, E. Indoxyl Sulfate and p-Cresyl Sulfate Promote Vascular Calcification and Associate with Glucose Intolerance. J. Am. Soc. Nephrol. 2019, 30, 751-766. [CrossRef]

140. Yamamoto, S.; Fuller, D.S.; Komaba, H.; Nomura, T.; Massy, Z.A.; Bieber, B.; Robinson, B.; Pisoni, R.; Fukagawa, M. Serum total indoxyl sulfate and clinical outcomes in hemodialysis patients: Results from the Japan Dialysis Outcomes and Practice Patterns Study. Clin. Kidney J. 2020, 14, 1236-1243. [CrossRef]

141. Gryp, T.; Vanholder, R.; Vaneechoutte, M.; Glorieux, G. p-Cresyl Sulfate. Toxins 2017, 9, 52. [CrossRef]

142. Rong, Y.; Kiang, T.K.L. Characterizations of Human UDP-Glucuronosyltransferase Enzymes in the Conjugation of p-Cresol. Toxicol. Sci. 2020, 176, 285-296. [CrossRef]

143. Poesen, R.; Viaene, L.; Verbeke, K.; Claes, K.; Bammens, B.; Sprangers, B.; Naesens, M.; Vanrenterghem, Y.; Kuypers, D.; Evenepoel, P.; et al. Renal clearance and intestinal generation of p-cresyl sulfate and indoxyl sulfate in CKD. Clin. J. Am. Soc. Nephrol. 2013, 8, 1508-1514. [CrossRef]

144. Mutsaers, H.A.; Caetano-Pinto, P.; Seegers, A.E.; Dankers, A.C.; van den Broek, P.H.; Wetzels, J.F.; van den Brand, J.A.; van den Heuvel, L.P.; Hoenderop, J.G.; Wilmer, M.J.; et al. Proximal tubular efflux transporters involved in renal excretion of p-cresyl sulfate and p-cresyl glucuronide: Implications for chronic kidney disease pathophysiology. Toxicol. In Vitro 2015, 29, 1868-1877. [CrossRef]

145. Watanabe, H.; Miyamoto, Y.; Honda, D.; Tanaka, H.; Wu, Q.; Endo, M.; Noguchi, T.; Kadowaki, D.; Ishima, Y.; Kotani, S.; et al. p-Cresyl sulfate causes renal tubular cell damage by inducing oxidative stress by activation of NADPH oxidase. Kidney Int. 2013, 83, 582-592. [CrossRef] [PubMed]

146. Azevedo, M.L.; Bonan, N.B.; Dias, G.; Brehm, F.; Steiner, T.M.; Souza, W.M.; Stinghen, A.E.; Barreto, F.C.; Elifio-Esposito, S.; PecoitsFilho, R.; et al. p-Cresyl sulfate affects the oxidative burst, phagocytosis process, and antigen presentation of monocyte-derived macrophages. Toxicol. Lett. 2016, 263, 1-5. [CrossRef] [PubMed]

147. Koppe, L.; Pillon, N.J.; Vella, R.E.; Croze, M.L.; Pelletier, C.C.; Chambert, S.; Massy, Z.; Glorieux, G.; Vanholder, R.; Dugenet, Y.; et al. p-Cresyl sulfate promotes insulin resistance associated with CKD. J. Am. Soc. Nephrol. 2013, 24, 88-99. [CrossRef] [PubMed]

148. Tanaka, H.; Iwasaki, Y.; Yamato, H.; Mori, Y.; Komaba, H.; Watanabe, H.; Maruyama, T.; Fukagawa, M. p-Cresyl sulfate induces osteoblast dysfunction through activating JNK and p38 MAPK pathways. Bone 2013, 56, 347-354. [CrossRef]

149. Rossi, M.; Campbell, K.L.; Johnson, D.W.; Stanton, T.; Vesey, D.A.; Coombes, J.S.; Weston, K.S.; Hawley, C.M.; McWhinney, B.C.; Ungerer, J.P.; et al. Protein-bound uremic toxins, inflammation and oxidative stress: A cross-sectional study in stage 3-4 chronic kidney disease. Arch. Med. Res. 2014, 45, 309-317. [CrossRef] [PubMed]

150. Lai, Y.H.; Wang, C.H.; Kuo, C.H.; Lin, Y.L.; Tsai, J.P.; Hsu, B.G. Serum P-Cresyl Sulfate Is a Predictor of Central Arterial Stiffness in Patients on Maintenance Hemodialysis. Toxins 2019, 12, 10. [CrossRef]

151. Lin, C.J.; Pan, C.F.; Chuang, C.K.; Sun, F.J.; Wang, D.J.; Chen, H.H.; Liu, H.L.; Wu, C.J. P-cresyl sulfate is a valuable predictor of clinical outcomes in pre-ESRD patients. Biomed. Res. Int. 2014, 2014, 526932. [CrossRef] [PubMed]

152. Bammens, B.; Evenepoel, P.; Keuleers, H.; Verbeke, K.; Vanrenterghem, Y. Free serum concentrations of the protein-bound retention solute p-cresol predict mortality in hemodialysis patients. Kidney Int. 2006, 69, 1081-1087. [CrossRef] [PubMed]

153. Liabeuf, S.; Barreto, D.V.; Barreto, F.C.; Meert, N.; Glorieux, G.; Schepers, E.; Temmar, M.; Choukroun, G.; Vanholder, R.; Massy, Z.A.; et al. Free p-cresylsulphate is a predictor of mortality in patients at different stages of chronic kidney disease. Nephrol. Dial. Transplant. 2010, 25, 1183-1191. [CrossRef] [PubMed]

154. Wu, I.W.; Hsu, K.H.; Hsu, H.J.; Lee, C.C.; Sun, C.Y.; Tsai, C.J.; Wu, M.S. Serum free p-cresyl sulfate levels predict cardiovascular and all-cause mortality in elderly hemodialysis patients-A prospective cohort study. Nephrol. Dial. Transplant. 2012, 27, 1169-1175. [CrossRef]

155. Yamamoto, S.; Tanaka, T.; Omori, K.; Ei, I.; Kitamura, N.; Narita, I. Severity of pruritus in hemodialysis patients: Relationship to uremic toxins and dialysis modality. Nephrol. Dial. Transplant. 2020, 35, gfaa142-P1509. [CrossRef]

156. Kim, S.J.; Zhang, X.; Cho, S.B.; Kim, C.H.; Park, H.C.; Moon, S.J. Uremic solutes of indoxyl sulfate and p-cresol enhance protease-activated receptor-2 expression in vitro and in vivo in keratinocytes. Hum. Exp. Toxicol. 2021, 40, 113-123. [CrossRef]

157. Steinhoff, M.; Neisius, U.; Ikoma, A.; Fartasch, M.; Heyer, G.; Skov, P.S.; Luger, T.A.; Schmelz, M. Proteinase-activated receptor-2 mediates itch: A novel pathway for pruritus in human skin. J. Neurosci. 2003, 23, 6176-6180. [CrossRef]

158. Akiyama, T.; Carstens, M.I.; Carstens, E. Excitation of mouse superficial dorsal horn neurons by histamine and/or PAR-2 agonist: Potential role in itch. J. Neurophysiol. 2009, 102, 2176-2183. [CrossRef]

159. Barr, T.P.; Garzia, C.; Guha, S.; Fletcher, E.K.; Nguyen, N.; Wieschhaus, A.J.; Ferrer, L.; Covic, L.; Kuliopulos, A. PAR2 PepducinBased Suppression of Inflammation and Itch in Atopic Dermatitis Models. J. Investig. Dermatol. 2019, 139, 412-421. [CrossRef] 
160. Moon, S.J.; Kim, H.J.; Cho, S.B.; Lee, S.H.; Choi, H.Y.; Park, H.C.; Ha, S.K. Epidermal Proteinase-Activated Receptor-2 Expression is Increased in End-Stage Renal Disease Patients with Pruritus: A Pilot Study. Electrolyte Blood Press. 2014, 12, 74-79. [CrossRef] [PubMed]

161. Cohen, G. Immune Dysfuntion in Uremia 2020. Toxins 2020, 12, 439. [CrossRef]

162. Tecklenborg, J.; Clayton, D.; Siebert, S.; Coley, S.M. The role of the immune system in kidney disease. Clin. Exp. Immunol. 2018, 192, 142-150. [CrossRef]

163. Fallahzadeh, M.K.; Roozbeh, J.; Geramizadeh, B.; Namazi, M.R. Interleukin-2 serum levels are elevated in patients with uremic pruritus: A novel finding with practical implications. Nephrol. Dial. Transplant. 2011, 26, 3338-3344. [CrossRef]

164. Abbas, A.K.; Trotta, E.; Simeonov, D.; Marson, A.; Bluestone, J.A. Revisiting IL-2: Biology and therapeutic prospects. Sci. Immunol. 2018, 3, eaat1482. [CrossRef]

165. Wahlgren, C.F.; Tengvall Linder, M.; Hägermark, O.; Scheynius, A. Itch and inflammation induced by intradermally injected interleukin-2 in atopic dermatitis patients and healthy subjects. Arch. Dermatol. Res. 1995, 287, 572-580. [CrossRef]

166. Darsow, U.; Scharein, E.; Bromm, B.; Ring, J. Skin testing of the pruritogenic activity of histamine and cytokines (interleukin-2 and tumour necrosis factor-alpha) at the dermal-epidermal junction. Br. J. Dermatol. 1997, 137, 415-417. [CrossRef]

167. Nakamura, M.; Toyoda, M.; Morohashi, M. Pruritogenic mediators in psoriasis vulgaris: Comparative evaluation of itch-associated cutaneous factors. Br. J. Dermatol. 2003, 149, 718-730. [CrossRef]

168. Lee, S.H.; Baig, M.; Rusciano, V.; Dutcher, J.P. Novel management of pruritus in patients treated with IL-2 for metastatic renal cell carcinoma and malignant melanoma. J. Immunother. 2010, 33, 1010-1013. [CrossRef]

169. Bağci, I.S.; Ruzicka, T. IL-31: A new key player in dermatology and beyond. J. Allergy Clin. Immunol. 2018, 141, 858-866. [CrossRef]

170. Hawro, T.; Saluja, R.; Weller, K.; Altrichter, S.; Metz, M.; Maurer, M. Interleukin-31 does not induce immediate itch in atopic dermatitis patients and healthy controls after skin challenge. Allergy 2014, 69, 113-117. [CrossRef] [PubMed]

171. Cevikbas, F.; Wang, X.; Akiyama, T.; Kempkes, C.; Savinko, T.; Antal, A.; Kukova, G.; Buhl, T.; Ikoma, A.; Buddenkotte, J.; et al. A sensory neuron-expressed IL-31 receptor mediates T helper cell-dependent itch: Involvement of TRPV1 and TRPA1. J. Allergy Clin. Immunol. 2014, 133, 448-460. [CrossRef] [PubMed]

172. Furue, M.; Yamamura, K.; Kido-Nakahara, M.; Nakahara, T.; Fukui, Y. Emerging role of interleukin-31 and interleukin-31 receptor in pruritus in atopic dermatitis. Allergy 2018, 73, 29-36. [CrossRef]

173. Ko, M.J.; Peng, Y.S.; Chen, H.Y.; Hsu, S.P.; Pai, M.F.; Yang, J.Y.; Wen, S.Y.; Jee, S.H.; Wu, H.Y.; Chiu, H.C. Interleukin-31 is associated with uremic pruritus in patients receiving hemodialysis. J. Am. Acad. Dermatol. 2014, 71, 1151-1159.e1. [CrossRef]

174. Oweis, A.O.; Al-Qarqaz, F.; Bodoor, K.; Heis, L.; Alfaqih, M.A.; Almomani, R.; Obeidat, M.A.; Alshelleh, S.A. Elevated interleukin 31 serum levels in hemodialysis patients are associated with uremic pruritus. Cytokine 2021, 138, 155369. [CrossRef]

175. Kinugasa, E.; Igawa, K.; Shimada, H.; Kondo, M.; Funakoshi, S.; Imada, N.; Itami, N.; Fukazawa, N.; Takubo, R.; Kawata, Y.; et al. Anti-pruritic effect of nemolizumab in hemodialysis patients with uremic pruritus: A phase II, randomized, double-blind, placebo-controlled clinical study. Clin. Exp. Nephrol. 2021. [CrossRef]

176. Feld, M.; Garcia, R.; Buddenkotte, J.; Katayama, S.; Lewis, K.; Muirhead, G.; Hevezi, P.; Plesser, K.; Schrumpf, H.; Krjutskov, K.; et al. The pruritus-and TH2-associated cytokine IL-31 promotes growth of sensory nerves. J. Allergy Clin. Immunol. 2016, 138, 500-508.e24. [CrossRef]

177. Da Silva, E.Z.; Jamur, M.C.; Oliver, C. Mast cell function: A new vision of an old cell. J. Histochem. Cytochem. 2014, 62, 698-738. [CrossRef]

178. Gupta, K.; Harvima, I.T. Mast cell-neural interactions contribute to pain and itch. Immunol. Rev. 2018, 282, 168-187. [CrossRef]

179. Siiskonen, H.; Harvima, I. Mast Cells and Sensory Nerves Contribute to Neurogenic Inflammation and Pruritus in Chronic Skin Inflammation. Front. Cell. Neurosci. 2019, 13, 422. [CrossRef]

180. Stockenhuber, F.; Kurz, R.W.; Sertl, K.; Grimm, G.; Balcke, P. Increased plasma histamine levels in uraemic pruritus. Clin. Sci. 1990, 79, 477-482. [CrossRef]

181. Gill, D.S.; Fonseca, V.A.; Barradas, M.A.; Balliod, R.; Moorhead, J.F.; Dandona, P. Plasma histamine in patients with chronic renal failure and nephrotic syndrome. J. Clin. Pathol. 1991, 44, 243-245. [CrossRef]

182. De Marchi, S.; Cecchin, E.; Villalta, D.; Sepiacci, G.; Santini, G.; Bartoli, E. Relief of pruritus and decreases in plasma histamine concentrations during erythropoietin therapy in patients with uremia. N. Engl. J. Med. 1992, 326, 969-974. [CrossRef]

183. Balaskas, E.V.; Bamihas, G.I.; Karamouzis, M.; Voyiatzis, G.; Tourkantonis, A. Histamine and serotonin in uremic pruritus: Effect of ondansetron in CAPD-pruritic patients. Nephron 1998, 78, 395-402. [CrossRef] [PubMed]

184. Mettang, T.; Fritz, P.; Weber, J.; Machleidt, C.; Hübel, E.; Kuhlmann, U. Uremic pruritus in patients on hemodialysis or continuous ambulatory peritoneal dialysis (CAPD). The role of plasma histamine and skin mast cells. Clin. Nephrol. 1990, 34, 136-141. [PubMed]

185. Francos, G.C.; Kauh, Y.C.; Gittlen, S.D.; Schulman, E.S.; Besarab, A.; Goyal, S.; Burke, J.F., Jr. Elevated plasma histamine in chronic uremia. Effects of ketotifen on pruritus. Int. J. Dermatol. 1991, 30, 884-889. [CrossRef]

186. De Filippi, C.; Regazzini, R.; Piazza, V.; Galli, F.; Pisati, P.; Sacchi, S.; Salvadeo, A. Uraemic pruritus is not related to plasma histamine concentrations. Clin. Exp. Dermatol. 1995, 20, 294-296. [CrossRef] 
187. Meixiong, J.; Anderson, M.; Limjunyawong, N.; Sabbagh, M.F.; Hu, E.; Mack, M.R.; Oetjen, L.K.; Wang, F.; Kim, B.S.; Dong, X. Activation of Mast-Cell-Expressed Mas-Related G-Protein-Coupled Receptors Drives Non-histaminergic Itch. Immunity 2019, 50, 1163-1171.e5. [CrossRef] [PubMed]

188. Dugas-Breit, S.; Schöpf, P.; Dugas, M.; Schiffl, H.; Ruëff, F.; Przybilla, B. Baseline serum levels of mast cell tryptase are raised in hemodialysis patients and associated with severity of pruritus. J. Dtsch. Dermatol. Ges. 2005, 3, 343-347. [CrossRef]

189. Voisin, T.; Chiu, I.M. Mast Cells Get on Your Nerves in Itch. Immunity 2019, 50, 1117-1119. [CrossRef]

190. Matsumoto, M.; Ichimaru, K.; Horie, A. Pruritus and mast cell proliferation of the skin in end stage renal failure. Clin. Nephrol. 1985, 23, 285-288.

191. Dimković, N.; Djukanović, L.; Radmilović, A.; Bojić, P.; Juloski, T. Uremic pruritus and skin mast cells. Nephron 1992, 61, 5-9. [CrossRef]

192. Leong, S.O.; Tan, C.C.; Lye, W.C.; Lee, E.J.; Chan, H.L. Dermal mast cell density and pruritus in end-stage renal failure. Ann. Acad. Med. Singap. 1994, 23, 327-329.

193. Szepietowski, J.; Thepen, T.; van Vloten, W.A.; Szepietowski, T.; Bihari, I.C. Pruritus and mast cell proliferation in the skin of haemodialysis patients. Inflamm. Res. 1995, 44, S84-S85. [CrossRef]

194. Szepietowski, J.C.; Morita, A.; Tsuji, T. Ultraviolet B induces mast cell apoptosis: A hypothetical mechanism of ultraviolet B treatment for uraemic pruritus. Med. Hypotheses 2002, 58, 167-170. [CrossRef] [PubMed]

195. Benarroch, E.E. Endogenous opioid systems: Current concepts and clinical correlations. Neurology 2012, 79, 807-814. [CrossRef]

196. Feng, Y.; He, X.; Yang, Y.; Chao, D.; Lazarus, L.H.; Xia, Y. Current research on opioid receptor function. Curr. Drug Targets 2012, 13, 230-246. [CrossRef] [PubMed]

197. Henriksen, G.; Willoch, F. Imaging of opioid receptors in the central nervous system. Brain 2008, 131, 1171-1196. [CrossRef]

198. Reed, B.; Butelman, E.R.; Kreek, M.J. Endogenous opioid system in addiction and addiction-related behaviors. Curr. Opin. Behav. Sci. 2017, 13, 196-202. [CrossRef]

199. Peciña, M.; Karp, J.F.; Mathew, S.; Todtenkopf, M.S.; Ehrich, E.W.; Zubieta, J.K. Endogenous opioid system dysregulation in depression: Implications for new therapeutic approaches. Mol. Psychiatry 2019, 24, 576-587. [CrossRef]

200. Cai, Z.; Ratka, A. Opioid system and Alzheimer's disease. Neuromol. Med. 2012, 14, 91-111. [CrossRef]

201. Reich, A.; Szepietowski, J.C. Opioid-induced pruritus: An update. Clin. Exp. Dermatol. 2010, 35, 2-6. [CrossRef]

202. Ko, M.C.; Song, M.S.; Edwards, T.; Lee, H.; Naughton, N.N. The role of central mu opioid receptors in opioid-induced itch in primates. J. Pharmacol. Exp. Ther. 2004, 310, 169-176. [CrossRef]

203. Ko, M.C.; Naughton, N.N. An experimental itch model in monkeys: Characterization of intrathecal morphine-induced scratching and antinociception. Anesthesiology 2000, 92, 795-805. [CrossRef] [PubMed]

204. Ko, M.C.; Husbands, S.M. Effects of atypical kappa-opioid receptor agonists on intrathecal morphine-induced itch and analgesia in primates. J. Pharmacol. Exp. Ther. 2009, 328, 193-200. [CrossRef] [PubMed]

205. Wang, Z.; Jiang, C.; Yao, H.; Chen, O.; Rahman, S.; Gu, Y.; Zhao, J.; Huh, Y.; Ji, R.R. Central opioid receptors mediate morphineinduced itch and chronic itch via disinhibition. Brain 2021, 144, 665-681. [CrossRef]

206. Taneda, K.; Tominaga, M.; Negi, O.; Tengara, S.; Kamo, A.; Ogawa, H.; Takamori, K. Evaluation of epidermal nerve density and opioid receptor levels in psoriatic itch. Br. J. Dermatol. 2011, 165, 277-284. [CrossRef]

207. Kupczyk, P.; Reich, A.; Hołysz, M.; Gajda, M.; Wysokińska, E.; Kobuszewska, A.; Nevozhay, D.; Nowakowska, B.; Strzadała, L.; Jagodziński, P.P.; et al. Opioid Receptors in Psoriatic Skin: Relationship with Itch. Acta Derm. Venereol. 2017, 97, 564-570. [CrossRef] [PubMed]

208. Tominaga, M.; Ogawa, H.; Takamori, K. Possible roles of epidermal opioid systems in pruritus of atopic dermatitis. J. Investig. Dermatol. 2007, 127, 2228-2235. [CrossRef]

209. Wieczorek, A.; Krajewski, P.; Kozioł-Gałczyńska, M.; Szepietowski, J.C. Opioid receptors expression in the skin of haemodialysis patients suffering from uraemic pruritus. J. Eur. Acad. Dermatol. Venereol. 2020, 34, 2368-2372. [CrossRef]

210. Danno, K.; Nishiura, K.; Tanaka, M. Increased met-enkephalin plasma levels in hemodialysis patients with or without pruritus. J. Dermatol. Sci. 1995, 10, 238-240. [CrossRef]

211. Georgala, S.; Schulpis, K.H.; Papaconstantinou, E.D.; Stratigos, J. Raised beta-endorphin serum levels in children with atopic dermatitis and pruritus. J. Dermatol. Sci. 1994, 8, 125-128. [CrossRef]

212. Glinski, W.; Brodecka, H.; Glinska-Ferenz, M.; Kowalski, D. Neuropeptides in psoriasis: Possible role of beta-endorphin in the pathomechanism of the disease. Int. J. Dermatol. 1994, 33, 356-360. [CrossRef]

213. Glinski, W.; Brodecka, H.; Glinska-Ferenz, M.; Kowalski, D. Increased concentration of beta-endorphin in sera of patients with psoriasis and other inflammatory dermatoses. Br. J. Dermatol. 1994, 131, 260-264. [CrossRef]

214. Lee, C.H.; Chuang, H.Y.; Shih, C.C.; Jong, S.B.; Chang, C.H.; Yu, H.S. Transepidermal water loss, serum IgE and beta-endorphin as important and independent biological markers for development of itch intensity in atopic dermatitis. Br. J. Dermatol. 2006, 154, 1100-1107. [CrossRef] [PubMed]

215. Espi, M.; Koppe, L.; Fouque, D.; Thaunat, O. Chronic Kidney Disease-Associated Immune Dysfunctions: Impact of Protein-Bound Uremic Retention Solutes on Immune Cells. Toxins 2020, 12, 300. [CrossRef]

216. Fabrizi, F.; Donato, F.M.; Messa, P. Association between hepatitis B virus and chronic kidney disease: A systematic review and meta-analysis. Ann. Hepatol. 2017, 16, 21-47. [CrossRef] [PubMed] 
217. Fabrizi, F.; Donato, F.M.; Messa, P. Association Between Hepatitis C Virus and Chronic Kidney Disease: A Systematic Review and Meta-Analysis. Ann. Hepatol. 2018, 17, 364-391. [CrossRef] [PubMed]

218. Tsui, J.I.; Vittinghoff, E.; Shlipak, M.G.; Bertenthal, D.; Inadomi, J.; Rodriguez, R.A.; O'Hare, A.M. Association of hepatitis C seropositivity with increased risk for developing end-stage renal disease. Arch. Intern. Med. 2007, 167, 1271-1276. [CrossRef] [PubMed]

219. Lee, J.J.; Lin, M.Y.; Chang, J.S.; Hung, C.C.; Chang, J.M.; Chen, H.C.; Yu, M.L.; Hwang, S.J. Hepatitis C virus infection increases risk of developing end-stage renal disease using competing risk analysis. PLoS ONE 2014, 9, e100790. [CrossRef] [PubMed]

220. Molnar, M.Z.; Alhourani, H.M.; Wall, B.M.; Lu, J.L.; Streja, E.; Kalantar-Zadeh, K.; Kovesdy, C.P. Association of hepatitis C viral infection with incidence and progression of chronic kidney disease in a large cohort of US veterans. Hepatology 2015, 61, 1495-1502. [CrossRef]

221. Fabrizi, F.; Cerutti, R.; Ridruejo, E. Hepatitis B virus infection as a risk factor for chronic kidney disease. Expert Rev. Clin. Pharmacol. 2019, 12, 867-874. [CrossRef] [PubMed]

222. Jadoul, M.; Bieber, B.A.; Martin, P.; Akiba, T.; Nwankwo, C.; Arduino, J.M.; Goodkin, D.A.; Pisoni, R.L. Prevalence, incidence, and risk factors for hepatitis $C$ virus infection in hemodialysis patients. Kidney Int. 2019, 95, 939-947. [CrossRef]

223. Fabrizi, F.; Marzano, A.; Messa, P.; Martin, P.; Lampertico, P. Hepatitis B virus infection in the dialysis population: Current perspectives. Int. J. Artif. Organs 2008, 31, 386-394. [CrossRef]

224. Bonacini, M. Pruritus in patients with chronic human immunodeficiency virus, hepatitis B and C virus infections. Dig. Liver Dis. 2000, 32, 621-625. [CrossRef]

225. Chiu, Y.L.; Chen, H.Y.; Chuang, Y.F.; Hsu, S.P.; Lai, C.F.; Pai, M.F.; Yang, S.Y.; Peng, Y.S. Association of uraemic pruritus with inflammation and hepatitis infection in haemodialysis patients. Nephrol. Dial. Transplant. 2008, 23, 3685-3689. [CrossRef] [PubMed]

226. Suzuki, K.; Tamano, M.; Katayama, Y.; Kuniyoshi, T.; Kagawa, K.; Takada, H.; Suzuki, K. Study of pruritus in chronic hepatitis C patients. World J. Gastroenterol. 2014, 20, 17877-17882. [CrossRef] [PubMed]

227. Oeda, S.; Takahashi, H.; Yoshida, H.; Ogawa, Y.; Imajo, K.; Yoneda, M.; Koshiyama, Y.; Ono, M.; Hyogo, H.; Kawaguchi, T.; et al. Prevalence of pruritus in patients with chronic liver disease: A multicenter study. Hepatol. Res. 2018, 48, E252-E262. [CrossRef] [PubMed]

228. Abdelsalam, M.; Tawfik, M.; Reda, E.M.; Eldeeb, A.A.; Abdelwahab, A.; Zaki, M.E.; Abdelkader Sobh, M. Insulin Resistance and Hepatitis C Virus-Associated Subclinical Inflammation Are Hidden Causes of Pruritus in Egyptian Hemodialysis Patients: A Multicenter Prospective Observational Study. Nephron 2019, 143, 120-127. [CrossRef] [PubMed]

229. Kossuth-Cabrejos, S.; Gavino-Gutiérrez, A.M.; Silva-Caso, W. Factors associated with the severity of pruritus in patients with terminal chronic kidney disease undergoing hemodialysis in Lima, Peru. Dermatol. Rep. 2020, 12, 8310. [CrossRef]

230. Alhmada, Y.; Selimovic, D.; Murad, F.; Hassan, S.L.; Haikel, Y.; Megahed, M.; Hannig, M.; Hassan, M. Hepatitis C virus-associated pruritus: Etiopathogenesis and therapeutic strategies. World J. Gastroenterol. 2017, 23, 743-750. [CrossRef] [PubMed]

231. Lempert, K.D.; Baltz, P.S.; Welton, W.A.; Whittier, F.C. Pseudouremic pruritus: A scabies epidemic in a dialysis unit. Am. J. Kidney Dis. 1985, 5, 117-119. [CrossRef]

232. Yates, J.E.; Bleyer, A.J.; Yosipovitch, G.; Sangueza, O.P.; Murea, M. Enigmatic pruritus in a kidney transplant patient. Clin. Kidney J. 2013, 6, 194-198. [CrossRef]

233. Augustin, M.; Kirsten, N.; Körber, A.; Wilsmann-Theis, D.; Itschert, G.; Staubach-Renz, P.; Maul, J.-T.; Zander, N. Prevalence, predictors and comorbidity of dry skin in the general population. J. Eur. Acad. Dermatol. Venereol. 2019, 33, 147-150. [CrossRef]

234. Wollenberg, A.; Christen-Zäch, S.; Taieb, A.; Paul, C.; Thyssen, J.P.; de Bruin-Weller, M.; Vestergaard, C.; Seneschal, J.; Werfel, T.; Cork, M.J.; et al. ETFAD/EADV Eczema task force 2020 position paper on diagnosis and treatment of atopic dermatitis in adults and children. J. Eur. Acad. Dermatol. Venereol. 2020, 34, 2717-2744. [CrossRef] [PubMed]

235. Szepietowski, J.C.; Reich, A.; Schwartz, R.A. Uraemic xerosis. Nephrol. Dial. Transplant. 2004, 19, 2709-2712. [CrossRef] [PubMed]

236. Wojtowicz-Prus, E.; Kilis-Pstrusinska, K.; Reich, A.; Zachwieja, K.; Miklaszewska, M.; Szczepanska, M.; Szepietowski, J.C. Disturbed skin barrier in children with chronic kidney disease. Pediatr. Nephrol. 2015, 30, 333-338. [CrossRef]

237. Morton, C.A.; Lafferty, M.; Hau, C.; Henderson, I.; Jones, M.; Lowe, J.G. Pruritus and skin hydration during dialysis. Nephrol. Dial. Transplant. 1996, 11, 2031-2036. [CrossRef]

238. Szepietowski, J.C.; Sikora, M.; Kusztal, M.; Salomon, J.; Magott, M.; Szepietowski, T. Uremic pruritus: A clinical study of maintenance hemodialysis patients. J. Dermatol. 2002, 29, 621-627. [CrossRef]

239. Balaskas, E.; Szepietowski, J.C.; Bessis, D.; Ioannides, D.; Ponticelli, C.; Ghienne, C.; Taberly, A.; Dupuy, P. Randomized, double-blind study with glycerol and paraffin in uremic xerosis. Clin. J. Am. Soc. Nephrol. 2011, 6, 748-752. [CrossRef] [PubMed]

240. Ståhle-Bäckdahl, M. Stratum corneum hydration in patients undergoing maintenance hemodialysis. Acta Derm. Venereol. 1988, 68, 531-534.

241. Park, T.H.; Park, C.H.; Ha, S.H.; Lee, S.H.; Song, K.S.; Lee, H.Y.; Han, D.S. Dry skin (xerosis) in patients undergoing maintenance haemodialysis: The role of decreased sweating of the eccrine sweat gland. Nephrol. Dial. Transplant. 1995, 10, $2269-2273$. [CrossRef]

242. Yosipovitch, G.; Reis, J.; Tur, E.; Sprecher, E.; Yarnitsky, D.; Boner, G. Sweat secretion, stratum corneum hydration, small nerve function and pruritus in patients with advanced chronic renal failure. Br. J. Dermatol. 1995, 133, 561-654. [CrossRef] 
243. Kato, A.; Hamada, M.; Maruyama, T.; Maruyama, Y.; Hishida, A. Pruritus and hydration state of stratum corneum in hemodialysis patients. Am. J. Nephrol. 2000, 20, 437-442. [CrossRef]

244. Chorążyczewska, W.; Reich, A.; Szepietowski, J.C. Lipid Content and Barrier Function Analysis in Uraemic Pruritus. Acta Derm. Venereol. 2016, 96, 402-403. [CrossRef]

245. Yosipovitch, G.; Duque, M.I.; Patel, T.S.; Ishiuji, Y.; Guzman-Sanchez, D.A.; Dawn, A.G.; Freedman, B.I.; Chan, Y.H.; Crumrine, D.; Elias, P.M. Skin barrier structure and function and their relationship to pruritus in end-stage renal disease. Nephrol. Dial. Transplant. 2007, 22, 3268-3272. [CrossRef] [PubMed]

246. Okada, K.; Matsumoto, K. Effect of skin care with an emollient containing a high water content on mild uremic pruritus. Ther. Apher. Dial. 2004, 8, 419-422. [CrossRef] [PubMed]

247. Szepietowski, J.C.; Reich, A.; Szepietowski, T. Emollients with endocannabinoids in the treatment of uremic pruritus: Discussion of the therapeutic options. Ther. Apher. Dial. 2005, 9, 277-279. [CrossRef] [PubMed]

248. Paus, R.; Schmelz, M.; Bíró, T.; Steinhoff, M. Frontiers in pruritus research: Scratching the brain for more effective itch therapy. J. Clin. Investig. 2006, 116, 1174-1186. [CrossRef] [PubMed]

249. Johannson, O.; Hilliges, M.; Ståhle-Bäckdahl, M. Intraepidermal neuron-specific enolase (NSE)-immunoreactive nerve fibres: Evidence for sprouting in uremic patients on maintenance hemodialysis. Neurosci. Lett. 1989, 99, 281-286. [CrossRef]

250. Fantini, F.; Baraldi, A.; Sevignani, C.; Spattini, A.; Pincelli, C.; Giannetti, A. Cutaneous innervation in chronic renal failure patients. An immunohistochemical study. Acta. Derm. Venereol. 1992, 72, 102-105.

251. Zakrzewska-Pniewska, B.; Jedras, M. Is pruritus in chronic uremic patients related to peripheral somatic and autonomic neuropathy? Study by R-R interval variation test (RRIV) and by sympathetic skin response (SSR). Neurophysiol. Clin. 2001, 31, 181-193. [CrossRef]

252. Papoiu, A.D.; Emerson, N.M.; Patel, T.S.; Kraft, R.A.; Valdes-Rodriguez, R.; Nattkemper, L.A.; Coghill, R.C.; Yosipovitch, G. Voxel-based morphometry and arterial spin labeling fMRI reveal neuropathic and neuroplastic features of brain processing of itch in end-stage renal disease. J. Neurophysiol. 2014, 112, 1729-1738. [CrossRef]

253. Yoganathan, S.; Bagga, A.; Gulati, S.; Toteja, G.S.; Hari, P.; Sinha, A.; Pandey, R.M.; Irshad, N. Prevalence and predictors of peripheral neuropathy in nondiabetic children with chronic kidney disease. Muscle Nerve 2018, 57, 792-798. [CrossRef]

254. Abd El Naby, S.A.; Bahbah, W.A.; Kasemy, Z.A.; Mahmoud, A.A. Neurophysiological and Neuroradiological Changes in Children With Chronic Kidney Disease. Front. Pediatr. 2020, 8, 570708. [CrossRef]

255. Matsuda-Abedini, M.; Fitzpatrick, K.; Harrell, W.R.; Gipson, D.S.; Hooper, S.R.; Belger, A.; Poskitt, K.; Miller, S.P.; Bjornson, B.H. Brain abnormalities in children and adolescents with chronic kidney disease. Pediatr. Res. 2018, 84, 387-392. [CrossRef] [PubMed]

256. Hartung, E.A.; Erus, G.; Jawad, A.F.; Laney, N.; Doshi, J.J.; Hooper, S.R.; Radcliffe, J.; Davatzikos, C.; Furth, S.L. Brain Magnetic Resonance Imaging Findings in Children and Young Adults With CKD. Am. J. Kidney Dis. 2018, 72, 349-359. [CrossRef] [PubMed]

257. Szepietowski, J.C.; Schwartz, R.A. Uremic pruritus. Int. J. Dermatol. 1998, 37, 247-253. [CrossRef]

258. Mettang, T. Pruritus in renal disease. In Itch: Mechanisms and Treatment; Carstens, E., Akiyama, T., Eds.; CRC Press/Taylor \& Francis: Boca Raton, FL, USA, 2014; pp. 47-59.

259. Aucella, F.; Vigilante, M.; Gesuete, A.; Maruccio, G.; Specchio, A.; Gesualdo, L. Uraemic itching: Do polymethylmethacrylate dialysis membranes play a role? Nephrol. Dial. Transplant. 2007, 22, v8-v12. [CrossRef]

260. Jiang, X.; Ji, F.; Chen, Z.-W.; Huang, Q.-L. Comparison of high-flux hemodialysis with hemodialysis filtration in treatment of uraemic pruritus: A randomized controlled trial. Int. Urol. Nephrol. 2016, 48, 1533-1541. [CrossRef]

261. Ko, M.-J.; Wu, H.Y.; Chen, H.-Y.; Chiu, Y.-L.; Hsu, S.-P.; Pai, M.-F.; Yang, J.-Y.; Lai, C.-F.; Lu, H.-M.; Huang, S.-C.; et al. Uremic pruritus, dialysis adequacy, and metabolic profiles in hemodialysis patients: A prospective 5-year cohort study. PLoS ONE 2013, 8, e71404. [CrossRef]

262. Vanholder, R.; Van Biesen, W.; Lameire, N. A swan song for Kt/V urea. Semin. Dial. 2019, 32, 424-437. [CrossRef]

263. Zucker, I.; Yosipovitch, G.; David, M.; Gafter, U.; Boner, G. Prevalence and characterization of uremic pruritus in patients undergoing hemodialysis: Uremic pruritus is still a major problem for patients with end-stage renal disease. J. Am. Acad. Dermatol. 2003, 49, 842-846. [CrossRef]

264. Dyachenko, P.; Shustak, A.; Rozenman, D. Hemodialysis-related pruritus and associated cutaneous manifestations. Int. J. Dermatol. 2006, 45, 664-667. [CrossRef]

265. Ding, L.; Johnston, J.; Pinsk, M.N. Monitoring dialysis adequacy: History and current practice. Pediatr. Nephrol. 2021. [CrossRef] [PubMed]

266. Berne, B.; Vahlquist, A.; Fischer, T.; Danielson, B.G.; Berne, C. UV treatment of uraemic pruritus reduces the vitamin A content of the skin. Eur. J. Clin. Investig. 1984, 14, 203-206. [CrossRef] [PubMed]

267. De Kroes, S.; Smeenk, G. Serum vitamin A levels and pruritus in patients on hemodialysis. Dermatologica 1983, 166, 199-202. [CrossRef] [PubMed]

268. Hsu, C.-W.; Weng, C.-H.; Chan, M.-J.; Lin-Tan, D.-T.; Yen, T.-H.; Huang, W.-H. Association Between Serum Aluminum Level and Uremic Pruritus in Hemodialysis Patients. Sci. Rep. 2018, 8, 17251. [CrossRef]

269. Cannata-Andía, H.G.; Fernández-Martín, J.L. The clinical impact of aluminium overload in renal failure. Nephrol. Dial. Transplant. 2002, 17, 9-12. [CrossRef] [PubMed]

270. Friga, V.; Linos, A.; Linos, D.A. Is aluminum toxicity responsible for uremic pruritus in chronic hemodialysis patients? Nephron 1997, 75, 48-53. [CrossRef] 
271. Song, S.; Lee, K.; Lee, Y.-M.; Lee, J.-H.; Lee, S.I.; Yu, S.-D.; Paek, D. Acute health effects of urban fine and ultrafine particles on children with atopic dermatitis. Environ. Res. 2011, 111, 394-399. [CrossRef]

272. Kim, J.; Kim, E.-H.; Oh, I.; Jung, K.; Han, Y.; Cheong, H.-K.; Ahn, K. Symptoms of atopic dermatitis are influenced by outdoor air pollution. J. Allergy Clin. Immunol. 2013, 132, 495-498.e1. [CrossRef]

273. Fadadu, R.P.; Grimes, B.; Jewell, N.P.; Vargo, J.; Young, A.T.; Abuabara, K.; Balmes, J.R.; Wei, M.L. Association of Wildfire Air Pollution and Health Care Use for Atopic Dermatitis and Itch. JAMA Dermatol. 2021, 157, 658-666. [CrossRef]

274. Whang, K.A.; Huang, A.H.; Miller, L.S.; Kang, S.; Kwatra, S.G. Association of particulate matter air pollution and itch: A digital epidemiology approach. J. Am. Acad. Dermatol. 2019, 81, 1409-1410. [CrossRef]

275. Huang, W.-H.; Lin, J.-H.; Weng, C.-H.; Hsu, C.-W.; Yen, T.-H. Environmental NO2 and CO Exposure: Ignored Factors Associated with Uremic Pruritus in Patients Undergoing Hemodialysis. Sci. Rep. 2016, 6, 31168. [CrossRef]

276. Liu, M.-H.; Chan, M.-J.; Hsu, C.-W.; Weng, C.-H.; Yen, T.-H.; Huang, W.-H. Association of uremic pruritus in hemodialysis patients with the number of days of high mean 24-hour particulate matter with a diameter of $<2.5 \mu \mathrm{m}$. Ther. Clin. Risk Manag. 2017, 13, 255-262. [CrossRef]

277. Hayani, K.; Kunzmann, K.; Mettang, T.; Weiss, M.; Tschulena, U.; Weisshaar, E. Lower prevalence of chronic itch in haemodialysis patients on loop diuretics: Results from GEHIS (German Epidemiological Hemodialysis Itch Study). J. Eur. Acad. Dermatol. Venereol. 2017, 31, 1333-1337. [CrossRef]

278. Moncrieff, G.; Cork, M.; Lawton, S.; Kokiet, S.; Daly, C.; Clark, C. Use of emollients in dry-skin conditions: Consensus statement. Clin. Exp. Dermatol. 2013, 38, 231-238. [CrossRef]

279. Castello, M.; Milani, M. Efficacy of topical hydrating and emollient lotion containing $10 \%$ urea ISDIN ${ }^{\circledR}$ plus dexpanthenol (Ureadin Rx 10) in the treatment of skin xerosis and pruritus in hemodialyzed patients: An open prospective pilot trial. G. Ital. Dermatol. Venereol. 2011, 146, 321-325. [PubMed]

280. Chen, Y.-C.; Chiu, W.-T.; Wu, M.-S. Therapeutic effect of topical gamma-linolenic acid on refractory uremic pruritus. Am. J. Kidney Dis. 2006, 48, 69-76. [CrossRef] [PubMed]

281. Young, T.A.; Patel, T.S.; Camacho, F.; Clark, A.; Freedman, B.I.; Kaur, M.; Fountain, J.; Williams, L.L.; Yosipovitch, G.; Fleischer, A.B., Jr. A pramoxine-based anti-itch lotion is more effective than a control lotion for the treatment of uremic pruritus in adult hemodialysis patients. J. Dermatol. Treat. 2009, 20, 76-81. [CrossRef] [PubMed]

282. Wassik, F.; Szepietowski, J.; Szepietowski, T.; Weyde, W. Relief of uraemic pruritus after balneological therapy with a bath oil containing polidocanol (Balneum Hernial Plus). An open clinical study. J. Dermatol. Treat. 1996, 7, 231-233. [CrossRef]

283. Breneman, D.L.; Cardone, J.S.; Blumsack, R.F.; Lather, R.M.; Searle, E.A.; Pollack, V.E. Topical capsaicin for treatment of hemodialysis-related pruritus. J. Am. Acad. Dermatol. 1992, 26, 91-94. [CrossRef]

284. Tarng, D.C.; Cho, Y.L.; Liu, H.N.; Huang, T.P. Hemodialysis-related pruritus: A double-blind, placebo-controlled, crossover study of capsaicin $0.025 \%$ cream. Nephron 1996, 72, 617-622. [CrossRef] [PubMed]

285. Makhlough, A.; Ala, S.; Haj-Heydari, S.; Kashi, Z.; Bari, A. Topical capsaicin therapy for uremic pruritus in patients on hemodialysis. Iran. J. Kidney Dis. 2010, 4, 137-140.

286. Gooding, S.M.D.; Canter, P.H.; Coelho, H.F.; Boddy, K.; Ernst, E. Systematic review of topical capsaicin in the treatment of pruritus. Int. J. Dermatol. 2010, 49, 858-865. [CrossRef]

287. Pauli-Magnus, C.; Klumpp, S.; Alscher, D.M.; Kuhlmann, U.; Mettang, T. Short-term efficacy of tacrolimus ointment in severe uremic pruritus. Perit. Dial. Int. 2000, 20, 802-803. [CrossRef]

288. Kuypers, D.R.; Claes, K.; Evenepoel, P.; Maes, B.; Vanrenterghem, Y. A prospective proof of concept study of the efficacy of tacrolimus ointment on uraemic pruritus (UP) in patients on chronic dialysis therapy. Nephrol. Dial. Transplant. 2004, 19, 1895-1901. [CrossRef]

289. Duque, M.I.; Yosipovitch, G.; Fleischer, A.B., Jr.; Willard, J.; Freedman, B.I. Lack of efficacy of tacrolimus ointment $0.1 \%$ for treatment of hemodialysis-related pruritus: A randomized, double-blind, vehicle-controlled study. J. Am. Acad. Dermatol. 2005, 52, 519-521. [CrossRef]

290. Ghorbani, A.R.; Feily, A.; Khalili, A.; Dormanesh, B. Lack of efficacy of topical calcineurin inhibitor pimecrolimus $1 \%$ on pruritus of severely uremic patients: A randomized double-blind study in 60 patients. Dermatitis 2011, 22, 167-168. [CrossRef]

291. Elmets, C.A.; Lim, H.W.; Stoff, B.; Connor, C.; Cordoro, K.M.; Lebwohl, M.; Armstrong, A.W.; Davis, D.M.R.; Elewski, B.E.; Gelfand, J.M.; et al. Joint American Academy of Dermatology-National Psoriasis Foundation guidelines of care for the management and treatment of psoriasis with phototherapy. J. Am. Acad. Dermatol. 2019, 81, 775-804. [CrossRef]

292. Wong, T.; Hsu, L.; Liao, W. Phototherapy in psoriasis: A review of mechanisms of action. J. Cutan. Med. Surg. 2013, 17, 6-12. [CrossRef]

293. DeSilva, B.; McKenzie, R.C.; Hunter, J.A.A.; Norval, M. Local effects of TL01 phototherapy in psoriasis. Photodermatol. Photoimmunol. Photomed. 2008, 24, 268-269. [CrossRef] [PubMed]

294. Osmancevic, A.; Landin-Wilhelmsen, K.; Larkö, O.; Krogstad, A.L. Vitamin D status in psoriasis patients during different treatments with phototherapy. J. Photochem. Photobiol. B 2010, 101, 117-123. [CrossRef] [PubMed]

295. Dotterud, L.K.; Wilsgaard, T.; Vorland, L.H.; Falk, E.S. The effect of UVB radiation on skin microbiota in patients with atopic dermatitis and healthy controls. Int. J. Circumpolar Health 2008, 67, 254-260. [CrossRef] 
296. Hong, S.P.; Kim, M.J.; Jung, M.-Y.; Jeon, H.; Goo, J.; Ahn, S.K.; Lee, S.H.; Elias, P.M.; Choi, E.H. Biopositive effects of low-dose UVB on epidermis: Coordinate upregulation of antimicrobial peptides and permeability barrier reinforcement. J. Investig. Dermatol. 2008, 128, 2880-2887. [CrossRef]

297. Legat, F.J.; Wolf, P. Cutaneous sensory nerves: Mediators of phototherapeutic effects? Front. Biosci. 2009, 14, 4921-4931. [CrossRef]

298. Gilchrest, B.A.; Rowe, J.W.; Brown, R.S.; Steinman, T.I.; Arndt, K.A. Relief of uremic pruritus with ultraviolet phototherapy. N. Engl. J. Med. 1977, 297, 136-138. [CrossRef]

299. Gilchrest, B.A.; Rowe, J.W.; Brown, R.S.; Steinman, T.I.; Arndt, K.A. Ultraviolet phototherapy of uremic pruritus. Long-term results and possible mechanism of action. Ann. Intern. Med. 1979, 91, 17-21. [CrossRef]

300. Schultz, B.C.; Roenigk, H.H., Jr. Uremic pruritus treated with ultraviolet light. JAMA 1980, 243, 1836-1837. [CrossRef]

301. Simpson, N.B.; Davison, A.M. Ultraviolet phototherapy for uraemic pruritus. Lancet 1981, 1, 781. [CrossRef]

302. Blachley, J.D.; Blankenship, D.M.; Menter, A.; Parker, T.F., 3rd; Knochel, J.P. Uremic pruritus: Skin divalent ion content and response to ultraviolet phototherapy. Am. J. Kidney Dis. 1985, 5, 237-241. [CrossRef]

303. Hsu, M.M.-L.; Yang, C.C. Uraemic pruritus responsive to broadband ultraviolet (UV) B therapy does not readily respond to narrowband UVB therapy. Br. J. Dermatol. 2003, 149, 888-889. [CrossRef]

304. Ada, S.; Seçkin, D.; Budakoğlu, I.; Ozdemir, F.N. Treatment of uremic pruritus with narrowband ultraviolet B phototherapy: An open pilot study. J. Am. Acad. Dermatol. 2005, 53, 149-151. [CrossRef]

305. Wang, T.-J.; Lan, L.-C.; Lu, C.-S.; Lin, K.-C.; Tung, H.-H.; Wu, S.-F.V.; Liang, S.-Y. Efficacy of narrowband ultraviolet phototherapy on renal pruritus. J. Clin. Nurs. 2014, 23, 1593-1602. [CrossRef] [PubMed]

306. Sherjeena, P.B.; Binitha, M.P.; Rajan, U.; Sreelatha, M.; Sarita, S.; Nirmal, C.; Deepthi, N.S. A controlled trial of narrowband ultraviolet B phototherapy for the treatment of uremic pruritus. Indian J. Dermatol. Venereol. Leprol. 2017, 83, 247-249. [CrossRef]

307. Sapam, R.; Waikhom, R. Role of narrow band ultra violet radiation as an add-on therapy in peritoneal dialysis patients with refractory uremic pruritus. World J. Nephrol. 2018, 7, 84-89. [CrossRef]

308. Ko, M.J.; Yang, J.Y.; Wu, H.-Y.; Hu, F.-C.; Chen, S.-I.; Tsai, P.-J.; Jee, S.-H.; Chiu, H.-C. Narrowband ultraviolet B phototherapy for patients with refractory uraemic pruritus: A randomized controlled trial. Br. J. Dermatol. 2011, 165, 633-639. [CrossRef]

309. Hercz, D.; Jiang, S.H.; Webster, A.C. Interventions for itch in people with advanced chronic kidney disease. Cochrane Database Syst. Rev. 2020, 12, CD011393. [CrossRef]

310. Leurs, R.; Church, M.K.; Taglialatela, M. H1-antihistamines, inverse agonism: Anti-inflammatory actions and cardiac effects. Clin. Exp. Allergy 2002, 32, 489-498. [CrossRef]

311. Church, D.S.; Church, M.K. Pharmacology of antihistamines. World Allergy Organ. J. 2011, 4, S22-S27. [CrossRef]

312. Kim, H.J.; Park, J.B.; Lee, J.H.; Kim, I.-H. How stress triggers itch: A preliminary study of the mechanism of stress-induced pruritus using fMRI. Int. J. Dermatol. 2016, 55, 434-442. [CrossRef]

313. Nakhaee, S.; Nasiri, A.; Waghei, Y.; Morshedi, J. Comparison of Avena sativa, vinegar, and hydroxyzine for uremic pruritus of hemodialysis patients: A crossover randomized clinical trial. Iran. J. Kidney Dis. 2015, 9, 316-322. [PubMed]

314. Kebar, S.M.; Sharghi, A.; Ghorghani, M.; Hoseininia, S. Comparison of gabapentin and hydroxyzine in the treatment of pruritus in patients on dialysis. Clin. Exp. Dermatol. 2020, 45, 866-871. [CrossRef]

315. Foroutan, N.; Etminan, A.; Nikvarz, N.; Abadi, M.S.S. Comparison of pregabalin with doxepin in the management of uremic pruritus: A randomized single blind clinical trial. Hemodial. Int. 2017, 21, 63-71. [CrossRef]

316. Haber, R.; Bachour, J.; Salloum, A.; Maacaron, T.; Khoury, F.; Habr, L.; Ammoury, A.; Joubran, N. Comparison of gabapentin and doxepin in the management of uremic pruritus: A randomized crossover clinical trial. Dermatol. Ther. 2020, 33, e14522. [CrossRef]

317. Amirkhanlou, S.; Rashedi, A.; Taherian, J.; Hafezi, A.A.; Parsaei, S. Comparison of Gabapentin and Ketotifen in Treatment of Uremic Pruritus in Hemodialysis Patients. Pak. J. Med. Sci. 2016, 32, 22-26. [CrossRef]

318. Marquez, D.; Ramonda, C.; Lauxmann, J.E.; Romero, C.E.; Vukelic, V.L.; Martinatto, C.; Barrón, B.; Novoa, P.A.; Peixoto, A.J.; Orías, M. Uremic pruritus in hemodialysis patients: Treatment with desloratidine versus gabapentin. Braz. J. Nephrol. 2012, 34, 148-152. [CrossRef]

319. Legroux-Crespel, E.; Clèdes, J.; Misery, L. A comparative study on the effects of naltrexone and loratadine on uremic pruritus. Dermatology 2004, 208, 326-330. [CrossRef]

320. Song, Y.-H.; Wang, S.-Y.; Lang, J.-H.; Xiao, Y.-F.; Cai, G.-Y.; Chen, X.-M. Therapeutic effect of intravenous sodium thiosulfate for uremic pruritus in hemodialysis patients. Ren. Fail. 2020, 42, 987-993. [CrossRef]

321. Kobayashi, K.; Endoh, F.; Ohmori, I.; Akiyama, T. Action of antiepileptic drugs on neurons. Brain Dev. 2020, 42, 2-5. [CrossRef]

322. Kaufman, K.R. Antiepileptic drugs in the treatment of psychiatric disorders. Epilepsy Behav. 2011, 21, 1-11. [CrossRef]

323. Eisenberg, E.; River, Y.; Shifrin, A.; Krivoy, N. Antiepileptic drugs in the treatment of neuropathic pain. Drugs 2007, 67, 1265-1289. [CrossRef]

324. Gunal, A.I.; Ozalp, G.; Yoldas, T.K.; Gunal, S.Y.; Kirciman, E.; Celiker, H. Gabapentin therapy for pruritus in haemodialysis patients: A randomized, placebo-controlled, double-blind trial. Nephrol. Dial. Transplant. 2004, 19, 3137-3139. [CrossRef]

325. Naini, A.E.; Harandi, A.A.; Khanbabapour, D.; Shahidi, S.; Seirafiyan, S.; Mohseni, M. Gabapentin: A promising drug for the treatment of uremic pruritus. Saudi J. Kidney Dis. Transpl. 2007, 18, 378-381.

326. Razeghi, E.; Eskandari, D.; Ganji, M.R.; Meysamie, A.P.; Togha, M.; Khashayar, P. Gabapentin and uremic pruritus in hemodialysis patients. Ren. Fail. 2009, 31, 85-90. [CrossRef] 
327. Rayner, H.; Baharani, J.; Smith, S.; Suresh, V.; Dasgupta, I. Uraemic pruritus: Relief of itching by gabapentin and pregabalin. Nephron Clin. Pract. 2012, 122, 75-79. [CrossRef]

328. Solak, Y.; Biyik, Z.; Atalay, H.; Gaipov, A.; Guney, F.; Turk, S.; Covic, A.; Goldsmith, D.; Kanbay, M. Pregabalin versus gabapentin in the treatment of neuropathic pruritus in maintenance haemodialysis patients: A prospective, crossover study. Nephrology 2012, 17, 710-717. [CrossRef]

329. Nofal, E.; Farag, F.; Nofal, A.; Eldesouky, F.; Alkot, R.; Abdelkhalik, Z. Gabapentin: A promising therapy for uremic pruritus in hemodialysis patients: A randomized-controlled trial and review of literature. J. Dermatol. Treat. 2016, 27, 515-519. [CrossRef]

330. Gobo-Oliveira, M.; Pigari, V.G.; Ogata, M.S.; Miot, H.A.; Ponce, D.; Abbade, L.P. Gabapentin versus dexchlorpheniramine as treatment for uremic pruritus: A randomised controlled trial. Eur. J. Dermatol. 2018, 28, 488-495. [CrossRef]

331. Rossi, G.M.; Corradini, M.; Blanco, V.; Mattei, S.; Fiaccadori, E.; Vaglio, A.; Manenti, L. Randomized trial of two after-dialysis gabapentin regimens for severe uremic pruritus in hemodialysis patients. Intern. Emerg. Med. 2019, 14, 1341-1346. [CrossRef]

332. Ravindran, A.; Kunnath, R.P.; Sunny, A.; Vimal, B. Comparison of Safety and Efficacy of Pregabalin versus Gabapentin for the treatment of Uremic Pruritus in Patients with Chronic Kidney Disease on Maintenance Haemodialysis. Indian J. Palliat. Care. 2020, 26, 281-286. [CrossRef]

333. Aperis, G.; Paliouras, C.; Zervos, A.; Arvanitis, A.; Alivanis, P. The use of pregabalin in the treatment of uraemic pruritus in haemodialysis patients. J. Ren. Care 2010, 36, 180-185. [CrossRef]

334. Shavit, L.; Grenader, T.; Lifschitz, M.; Slotki, I. Use of pregabalin in the management of chronic uremic pruritus. J. Pain Symptom Manag. 2013, 45, 776-781. [CrossRef]

335. Yue, J.; Jiao, S.; Xiao, Y.; Ren, W.; Zhao, W.; Meng, J. Comparison of pregabalin with ondansetron in treatment of uraemic pruritus in dialysis patients: A prospective, randomized, double-blind study. Int. Urol. Nephrol. 2015, 47, 161-167. [CrossRef]

336. Khan, T.M.; Wu, D.B.-C.; Goh, B.-H.; Lee, L.-H.; Alhafez, A.A.; Sulaiman, S.A.S. An Observational Longitudinal Study Investigating the Effectiveness of $75 \mathrm{mg}$ Pregabalin Post-Hemodialysis among Uremic Pruritus Patients. Sci. Rep. 2016, 6, 36555. [CrossRef]

337. Mendham, J.E. Gabapentin for the treatment of itching produced by burns and wound healing in children: A pilot study. Burns 2004, 30, 851-853. [CrossRef]

338. Goutos, I.; Eldardiri, M.; Khan, A.A.; Dziewulski, P.; Richardson, P.M. Comparative evaluation of antipruritic protocols in acute burns. The emerging value of gabapentin in the treatment of burns pruritus. J. Burn Care Res. 2010, 31, 57-63. [CrossRef]

339. Ahuja, R.B.; Gupta, R.; Gupta, G.; Shrivastava, P. A comparative analysis of cetirizine, gabapentin and their combination in the relief of post-burn pruritus. Burns 2011, 37, 203-207. [CrossRef]

340. Kaul, I.; Amin, A.; Rosenberg, M.; Rosenberg, L.; Meyer, W.J., 3rd. Use of gabapentin and pregabalin for pruritus and neuropathic pain associated with major burn injury: A retrospective chart review. Burns 2018, 44, 414-422. [CrossRef] [PubMed]

341. Christofaki, M.; Papaioannou, A. Ondansetron: A review of pharmacokinetics and clinical experience in postoperative nausea and vomiting. Expert Opin. Drug Metab. Toxicol. 2014, 10, 437-444. [CrossRef] [PubMed]

342. Juza, R.; Vlcek, P.; Mezeiova, E.; Musilek, K.; Soukup, O.; Korabecny, J. Recent advances with 5-HT 3 modulators for neuropsychiatric and gastrointestinal disorders. Med. Res. Rev. 2020, 40, 1593-1678. [CrossRef]

343. Raderer, M.; Müller, C.; Scheithauer, W. Ondansetron for pruritus due to cholestasis. N. Engl. J. Med. 1994, 330, 1540. [CrossRef]

344. Müller, C.; Pongratz, S.; Pidlich, J.; Penner, E.; Kaider, A.; Schemper, M.; Raderer, M.; Scheithauer, W.; Ferenci, P. Treatment of pruritus in chronic liver disease with the 5-hydroxytryptamine receptor type 3 antagonist ondansetron: A randomized, placebo-controlled, double-blind cross-over trial. Eur. J. Gastroenterol. Hepatol. 1998, 10, 865-870. [CrossRef] [PubMed]

345. Jones, E.A.; Molenaar, H.A.J.; Oosting, J. Ondansetron and pruritus in chronic liver disease: A controlled study. Hepatogastroenterology 2007, 54, 1196-1199.

346. Schwörer, H.; Hartmann, H.; Ramadori, G. Relief of cholestatic pruritus by a novel class of drugs: 5-hydroxytryptamine type 3 (5-HT3) receptor antagonists: Effectiveness of ondansetron. Pain 1995, 61, 33-37. [CrossRef]

347. O'Donohue, J.W.; Pereira, S.P.; Ashdown, A.C.; Haigh, C.G.; Wilkinson, J.R.; Williams, R. A controlled trial of ondansetron in the pruritus of cholestasis. Aliment. Pharmacol. Ther. 2005, 21, 1041-1045. [CrossRef] [PubMed]

348. Tzeng, J.-I.; Chu, K.-S.; Ho, S.-T.; Cheng, K.-I.; Liu, K.-S.; Wang, J.-J. Prophylactic iv ondansetron reduces nausea, vomiting and pruritus following epidural morphine for postoperative pain control. Can. J. Anaesth. 2003, 50, 1023-1026. [CrossRef] [PubMed]

349. Sarvela, P.J.; Halonen, P.M.; Soikkeli, A.I.; Kainu, J.P.; Korttila, K.T. Ondansetron and tropisetron do not prevent intraspinal morphine- and fentanyl-induced pruritus in elective cesarean delivery. Acta Anaesthesiol. Scand. 2006, 50, 239-244. [CrossRef]

350. Han, D.W.; Hong, S.W.; Kwon, J.-Y.; Lee, J.W.; Kim, K.J. Epidural ondansetron is more effective to prevent postoperative pruritus and nausea than intravenous ondansetron in elective cesarean delivery. Acta Obstet. Gynecol. Scand. 2007, 86, 683-687. [CrossRef] [PubMed]

351. Ashmore, S.D.; Jones, C.H.; Newstead, C.G.; Daly, M.J.; Chrystyn, H. Ondansetron therapy for uremic pruritus in hemodialysis patients. Am. J. Kidney Dis. 2000, 35, 827-831. [CrossRef]

352. Murphy, M.; Reaich, D.; Pai, P.; Finn, P.; Carmichael, A.J. A randomized, placebo-controlled, double-blind trial of ondansetron in renal itch. Br. J. Dermatol. 2003, 148, 314-317. [CrossRef]

353. Weisshaar, E.; Dunker, N.; Röhl, F.-W.; Gollnick, H. Antipruritic effects of two different 5-HT3 receptor antagonists and an antihistamine in haemodialysis patients. Exp. Dermatol. 2004, 13, 298-304. [CrossRef] 
354. Patel, K.P.; Luo, F.J.; Plummer, N.S.; Hostetter, T.H.; Meyer, T.W. The production of p-cresol sulfate and indoxyl sulfate in vegetarians versus omnivores. Clin. J. Am. Soc. Nephrol. 2012, 7, 982-988. [CrossRef]

355. Marzocco, S.; Dal Piaz, F.; Di Micco, L.; Torraca, S.; Sirico, M.L.; Tartaglia, D.; Autore, G.; Di Iorio, B. Very low protein diet reduces indoxyl sulfate levels in chronic kidney disease. Blood Purif. 2013, 35, 196-201. [CrossRef]

356. Di Iorio, B.R.; Rocchetti, M.T.; De Angelis, M.; Cosola, C.; Marzocco, S.; Di Micco, L.; di Bari, I.; Accetturo, M.; Vacca, M.; Gobbetti, M.; et al. Nutritional Therapy Modulates Intestinal Microbiota and Reduces Serum Levels of Total and Free Indoxyl Sulfate and P-Cresyl Sulfate in Chronic Kidney Disease (Medika Study). J. Clin. Med. 2019, 8, 1424. [CrossRef]

357. Sirich, T.L.; Plummer, N.S.; Gardner, C.D.; Hostetter, T.H.; Meyer, T.W. Effect of increasing dietary fiber on plasma levels of colon-derived solutes in hemodialysis patients. Clin. J. Am. Soc. Nephrol. 2014, 9, 1603-1610. [CrossRef]

358. Rossi, M.; Johnson, D.W.; Xu, H.; Carrero, J.J.; Pascoe, E.; French, C.; Campbell, K.L. Dietary protein-fiber ratio associates with circulating levels of indoxyl sulfate and p-cresyl sulfate in chronic kidney disease patients. Nutr. Metab. Cardiovasc. Dis. 2015, 25, 860-865. [CrossRef]

359. Lu, L.; Huang, Y.-F.; Wang, M.-Q.; Chen, D.-X.; Wan, H.; Wei, L.-B.; Xiao, W. Dietary fiber intake is associated with chronic kidney disease (CKD) progression and cardiovascular risk, but not protein nutritional status, in adults with CKD. Asia Pac. J. Clin. Nutr. 2017, 26, 598-605. [CrossRef] [PubMed]

360. Chaturvedi, S.; Jones, C. Protein restriction for children with chronic renal failure. Cochrane Database Syst. Rev. 2007, 4, CD006863. [CrossRef]

361. Takayama, F.; Taki, K.; Niwa, T. Bifidobacterium in gastro-resistant seamless capsule reduces serum levels of indoxyl sulfate in patients on hemodialysis. Am. J. Kidney Dis. 2003, 41, S142-S145. [CrossRef]

362. Lim, P.S.; Wang, H.F.; Lee, M.C.; Chiu, L.-S.; Wu, M.-Y.; Chang, W.-C.; Wu, T.K. The Efficacy of Lactobacillus-Containing Probiotic Supplementation in Hemodialysis Patients: A Randomized, Double-Blind, Placebo-Controlled Trial. J. Ren. Nutr. 2021, 31, 189-198. [CrossRef] [PubMed]

363. Meijers, B.K.; De Preter, V.; Verbeke, K.; Vanrenterghem, Y.; Evenepoel, P. p-Cresyl sulfate serum concentrations in haemodialysis patients are reduced by the prebiotic oligofructose-enriched inulin. Nephrol. Dial. Transplant. 2010, 25, 219-224. [CrossRef]

364. Cosola, C.; De Angelis, M.; Rocchetti, M.T.; Montemurno, E.; Maranzano, V.; Dalfino, G.; Manno, C.; Zito, A.; Gesualdo, M.; Ciccone, M.M.; et al. Beta-Glucans Supplementation Associates with Reduction in P-Cresyl Sulfate Levels and Improved Endothelial Vascular Reactivity in Healthy Individuals. PLoS ONE 2017, 12, e0169635. [CrossRef] [PubMed]

365. Esgalhado, M.; Kemp, J.A.; Azevedo, R.; Paiva, B.R.; Stockler-Pinto, M.B.; Dolenga, C.J.; Borges, N.A.; Nakao, L.S.; Mafra, D. Could resistant starch supplementation improve inflammatory and oxidative stress biomarkers and uremic toxins levels in hemodialysis patients? A pilot randomized controlled trial. Food Funct. 2018, 9, 6508-6516. [CrossRef]

366. De Preter, V.; Vanhoutte, T.; Huys, G.; Swings, J.; De Vuyst, L.; Rutgeerts, P.; Verbeke, K. Effects of Lactobacillus casei Shirota, Bifidobacterium breve, and oligofructose-enriched inulin on colonic nitrogen-protein metabolism in healthy humans. Am. J. Physiol. Gastrointest. Liver Physiol. 2007, 292, G358-G368. [CrossRef]

367. Nakabayashi, I.; Nakamura, M.; Kawakami, K.; Ohta, T.; Kato, I.; Uchida, K.; Yoshida, M. Effects of synbiotic treatment on serum level of p-cresol in haemodialysis patients: A preliminary study. Nephrol. Dial. Transplant. 2011, 26, 1094-1098. [CrossRef]

368. Guida, B.; Germano, R.; Trio, R.; Russo, D.; Memoli, B.; Grumetto, L.; Barbato, F.; Cataldi, M. Effect of short-term synbiotic treatment on plasma p-cresol levels in patients with chronic renal failure: A randomized clinical trial. Nutr. Metab. Cardiovasc. Dis. 2014, 24, 1043-1049. [CrossRef] [PubMed]

369. Rossi, M.; Johnson, D.W.; Morrison, M.; Pascoe, E.M.; Coombes, J.S.; Forbes, J.M.; Szeto, C.C.; McWhinney, B.C.; Ungerer, J.P.; Campbell, K.L. Synbiotics Easing Renal Failure by Improving Gut Microbiology (SYNERGY): A Randomized Trial. Clin. J. Am. Soc. Nephrol. 2016, 11, 223-231. [CrossRef]

370. Lopes, R.d.-C.S.O.; Theodoro, J.M.V.; da Silva, B.P.; Queiroz, V.A.V.; de Castro Moreira, M.E.; Mantovani, H.C.; Hermsdorff, H.H.; Martino, H.S.D. Synbiotic meal decreases uremic toxins in hemodialysis individuals: A placebo-controlled trial. Food Res. Int. 2019, 116, 241-248. [CrossRef] [PubMed]

371. Borges, N.A.; Carmo, F.L.; Stockler-Pinto, M.B.; de Brito, J.S.; Dolenga, C.J.; Ferreira, D.C.; Nakao, L.S.; Rosado, A.; Fouque, D.; Mafra, D. Probiotic Supplementation in Chronic Kidney Disease: A Double-blind, Randomized, Placebo-controlled Trial. J. Ren. Nutr. 2018, 28, 28-36. [CrossRef]

372. Hyun, H.S.; Paik, K.H.; Cho, H.Y. p-Cresyl sulfate and indoxyl sulfate in pediatric patients on chronic dialysis. Korean J. Pediatr. 2013, 56, 159-164. [CrossRef]

373. Ikee, R.; Sasaki, N.; Yasuda, T.; Fukazawa, S. Chronic Kidney Disease, Gut Dysbiosis, and Constipation: A Burdensome Triplet. Microorganisms 2020, 8, 1862. [CrossRef]

374. Ramos, C.I.; Armani, R.G.; Canziani, M.E.; Dolenga, C.J.R.; Nakao, L.S.; Campbell, K.L.; Cuppari, L. Bowel Habits and the Association With Uremic Toxins in Non-Dialysis-Dependent Chronic Kidney Disease Patients. J. Ren. Nutr. 2020, $30,31-35$. [CrossRef] [PubMed]

375. Pereira, N.B.F.; Ramos, C.I.; Santos de Andrade, L.; Rodrigues Teixeira, R.; Nakao, L.S.; Rodrigues, S.D.; de Lima, J.D.; Dalboni, M.A.; Cuppari, L. Influence of bowel habits on gut-derived toxins in peritoneal dialysis patients. J. Nephrol. 2020, 33, 1049-1057. [CrossRef] [PubMed]

376. Pederson, J.A.; Matter, B.J.; Czerwinski, A.W.; Llach, F. Relief of idiopathic generalized pruritus in dialysis patients treated with activated oral charcoal. Ann. Intern. Med. 1980, 93, 446-448. [CrossRef] [PubMed] 
377. Giovannetti, S.; Barsotti, G.; Cupisti, A.; Dani, L.; Bandini, S.; Angelini, D.; Antonelli, A.; Salvadori, M.; Urti, D.A. Oral activated charcoal in patients with uremic pruritus. Nephron 1995, 70, 193-196. [CrossRef]

378. Fusaro, R.M. A contraindication for the use of charcoal in uremic patients. J. Am. Acad. Dermatol. 1981, 5, 219. [CrossRef]

379. Asai, M.; Kumakura, S.; Kikuchi, M. Review of the efficacy of AST-120 (KREMEZIN ${ }^{\circledR}$ ) on renal function in chronic kidney disease patients. Ren. Fail. 2019, 41, 47-56. [CrossRef]

380. Schulman, G.; Berl, T.; Beck, G.J.; Remuzzi, G.; Ritz, E.; Arita, K.; Kato, A.; Shimizu, M. Randomized placebo-controlled EPPIC trials of AST-120 in CKD. J. Am. Soc. Nephrol. 2015, 26, 1732-1746. [CrossRef]

381. Cha, R.H.; Kang, S.W.; Park, C.W.; Cha, D.R.; Na, K.Y.; Kim, S.G.; Yoon, S.A.; Han, S.Y.; Chang, J.H.; Park, S.K.; et al. A Randomized, Controlled trial of oral intestinal sorbent AST-120 on Renal function deterioration in patients with advanced renal dysfunction. Clin. J. Am. Soc. Nephrol. 2016, 11, 559-567. [CrossRef]

382. Niwa, T.; Emoto, Y.; Maeda, K.; Uehara, Y.; Yamada, N.; Shibata, M. Oral sorbent suppresses accumulation of albumin-bound indoxyl sulphate in serum of haemodialysis patients. Nephrol. Dial. Transplant. 1991, 6, 105-109. [CrossRef]

383. Meert, N.; Eloot, S.; Waterloos, M.A.; Van Landschoot, M.; Dhondt, A.; Glorieux, G.; Ledebo, I.; Vanholder, R. Effective removal of protein-bound uraemic solutes by different convective strategies: A prospective trial. Nephrol. Dial. Transplant. 2009, 24, 562-570. [CrossRef]

384. Krieter, D.H.; Hackl, A.; Rodriguez, A.; Chenine, L.; Moragues, H.L.; Lemke, H.D.; Wanner, C.; Canaud, B. Protein-bound uraemic toxin removal in haemodialysis and post-dilution haemodiafiltration. Nephrol. Dial. Transplant. 2010, 25, 212-218. [CrossRef] [PubMed]

385. Meert, N.; Eloot, S.; Schepers, E.; Lemke, H.D.; Dhondt, A.; Glorieux, G.; Van Landschoot, M.; Waterloos, M.A.; Vanholder, R. Comparison of removal capacity of two consecutive generations of high-flux dialysers during different treatment modalities. Nephrol. Dial. Transplant. 2011, 26, 2624-2630. [CrossRef] [PubMed]

386. Van Gelder, M.K.; Middel, I.R.; Vernooij, R.W.M.; Bots, M.L.; Verhaar, M.C.; Masereeuw, R.; Grooteman, M.P.; Nubé, N.J.; van den Dorpel, M.A.; Blankestijn, P.J.; et al. Protein-Bound Uremic Toxins in Hemodialysis Patients Relate to Residual Kidney Function, Are Not Influenced by Convective Transport, and Do Not Relate to Outcome. Toxins 2020, 12, 234. [CrossRef] [PubMed]

387. Krieter, D.H.; Kerwagen, S.; Rüth, M.; Lemke, H.-D.; Wanner, C. Differences in Dialysis Efficacy Have Limited Effects on Protein-Bound Uremic Toxins Plasma Levels over Time. Toxins 2019, 11, 47. [CrossRef] [PubMed]

388. Brettschneider, F.; Tolle, M.; von der Giet, M.; Passlick-Deetjen, J.; Steppan, S.; Peter, M.; Jankowski, V.; Krause, A.; Kuhne, S.; Zidek, W.; et al. Removal of protein-bound, hydrophobic uremic toxins by a combined fractionated plasma separation and adsorption technique. Artif. Organs 2013, 37, 409-416. [CrossRef]

389. Saar-Kovrov, V.; Zidek, W.; Orth-Alampour, S.; Fliser, D.; Jankowski, V.; Biessen, E.A.L.; Jankowski, J. Reduction of protein-bound uraemic toxins in plasma of chronic renal failure patients: A systematic review. J. Intern. Med. 2021. [CrossRef]

390. Rocchetti, M.T.; Cosola, C.; di Bari, I.; Magnani, S.; Galleggiante, V.; Scandiffio, L.; Dalfino, G.; Netti, G.S.; Atti, M.; Corciulo, R.; et al. Efficacy of Divinylbenzenic Resin in Removing Indoxyl Sulfate and P-Cresol Sulfate in Hemodialysis Patients: Results From an In Vitro Study and An In Vivo Pilot Trial (xuanro4-Nature 3.2). Toxins 2020, 12, 170. [CrossRef]

391. Pavlenko, D.; van Geffen, E.; van Steenbergen, M.J.; Glorieux, G.; Vanholder, R.; Gerritsen, K.G.F.; Stamatialis, D. New low-flux mixed matrix membranes that offer superior removal of protein-bound toxins from human plasma. Sci. Rep. 2016, 6, 34429. [CrossRef]

392. Yamamoto, S.; Ito, T.; Sato, M.; Goto, S.; Kazama, J.J.; Gejyo, F.; Narita, I. Adsorption of Protein-Bound Uremic Toxins Using Activated Carbon through Direct Hemoperfusion in vitro. Blood Purif. 2019, 48, 215-222. [CrossRef]

393. Shi, Y.; Wang, Y.; Ma, S.; Liu, T.; Tian, H.; Zhu, Q.; Wang, W.; Li, Y.; Ding, F. Increasing the removal of protein-bound uremic toxins by liposome-supported hemodialysis. Artif. Organs 2019, 43, 490-503. [CrossRef]

394. Madero, M.; Cano, K.B.; Campos, I.; Tao, X.; Maheshwari, V.; Brown, J.; Cornejo, B.; Handelman, G.; Thijssen, S.; Kotanko, P. Removal of Protein-Bound Uremic Toxins during Hemodialysis Using a Binding Competitor. Clin. J. Am. Soc. Nephrol. 2019, 14, 394-402. [CrossRef] [PubMed]

395. Meert, N.; Waterloos, M.A.; Van Landschoot, M.; Dhondt, A.; Ledebo, I.; Glorieux, G.; Goeman, J.; Van der Eycken, J.; Vanholder, R. Prospective evaluation of the change of predialysis protein-bound uremic solute concentration with postdilution online hemodiafiltration. Artif. Organs 2010, 34, 580-585. [CrossRef] [PubMed]

396. Marquez, I.O.; Tambra, S.; Luo, F.Y.; Li, Y.; Plummer, N.S.; Hostetter, T.H.; Meyer, T.W. Contribution of residual function to removal of protein-bound solutes in hemodialysis. Clin. J. Am. Soc. Nephrol. 2011, 6, 290-296. [CrossRef]

397. Toth-Manikowski, S.M.; Sirich, T.L.; Meyer, T.W.; Hostetter, T.H.; Hwang, S.; Plummer, N.S.; Hai, X.; Coresh, J.; Powe, N.R.; Shafi, T. Contribution of 'clinically negligible' residual kidney function to clearance of uremic solutes. Nephrol. Dial. Transplant. 2020, 35, 846-853. [CrossRef] [PubMed]

398. Poesen, R.; Evenepoel, P.; de Loor, H.; Bammens, B.; Claes, K.; Sprangers, B.; Naesens, M.; Kuypers, D.; Augustijns, P.; Meijers, B. The influence of renal transplantation on retained microbial-human co-metabolites. Nephrol. Dial. Transplant. 2016, 31, 1721-1729. [CrossRef]

399. Liabeuf, S.; Desjardins, L.; Massy, Z.A.; Brazier, F.; Westeel, P.F.; Mazouz, H.; Titeca-Beauport, D.; Diouf, M.; Glorieux, G.; Vanholder, R. Levels of Indoxyl Sulfate in Kidney Transplant Patients, and the Relationship With Hard Outcomes. Circ. J. 2016, 80, 722-730. [CrossRef] 